This manuscript, Progradational Slope Architecture and Sediment Partitioninig in the Outcropping Mixed Siliciclastic-Carbonate Bone Spring Formation, Permian Basin, west Texas, is a preprint and has been submitted for publication in Geosphere. The manuscript is currently in peer-review but has not had final acceptance and therefore subsequent versions of this manuscript may have updated content. Please feel free to contact the authors Wylie Walker (wylie.walker@gmail.com) or Zane Jobe (zanejobe@ mines.edu) for questions regarding the manuscript 


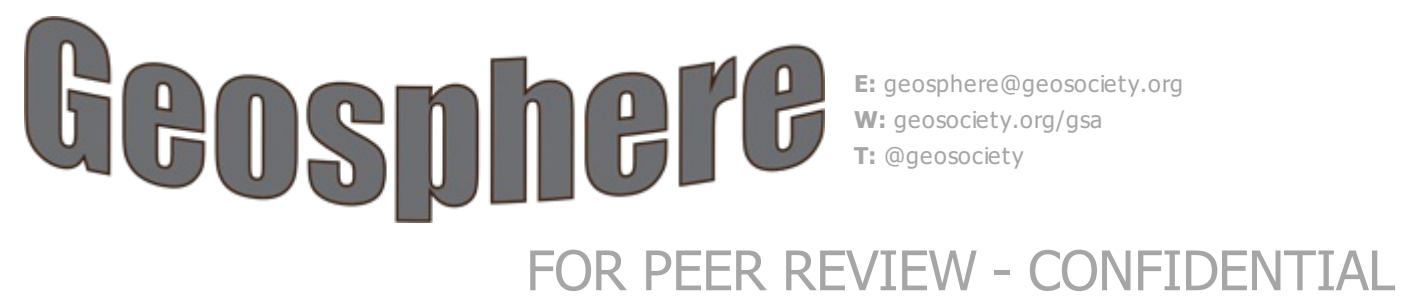

\title{
Progradational Slope Architecture and Sediment Partitioning in the Outcropping Mixed Siliciclastic-Carbonate Bone Spring Formation, Permian Basin, west Texas
}

Tracking no: GS2184

Authors:

Wylie Walker (Colorado School of Mines), Zane Jobe (Colorado School of Mines), Rick Sarg, and Lesli Wood (Colorado School of Mines)

\begin{abstract}
:
Sediment transport and partitioning are important for understanding slope-building processes in mixed carbonate-siliciclastic sediment routing systems. The Permian-aged Bone Spring Formation, Delaware Basin, west Texas is a mixed carbonate-siliciclastic system that has been extensively studied in its basinal extent, but poorly constrained at its proximal, upper slope segment. In this study, we constrain the stratigraphic architecture of the proximal Bone Spring Fm. outcrops in Guadalupe Mountains National Park in order to delineate the dynamics of carbonate and siliciclastic sediment delivery to the basin. These upper-slope deposits are composed predominantly of fine-grained carbonate slope facies interbedded at various scales with terrigenous hemipelagic and sediment gravity flow deposits. We identify ten slope-building clinothems that vary from siliciclastic-rich to carbonate-rich and are truncated by slope detachment surfaces that record large-scale masswasting of the shelf margin. X-ray fluorescence (XRF) data indicates that slope detachment surfaces contain a higher-than-normal proportion of terrigenous siliciclastic sediment, suggesting failure is triggered by accommodation or sediment supply changes at the shelf margin. Furthermore, a well-exposed siliciclastic-rich clinothem, identified here as the 1st Bone Spring Sand, provides evidence that carbonate and terrigenous sediment were deposited contemporaneously, suggesting both autogenic and allogenic processes influenced the Bone Spring Fm. stratigraphy. This mixing of lithologies at multiple scales and the prevalence of mass-wasting act as a primary control on the stacking patterns of siliciclastic and carbonate lithologies on not only the Bone Spring margin, but also in the distal portion of the Delaware Basin.
\end{abstract}


1 Progradational Slope Architecture and Sediment Partitioning in the

2 Outcropping Mixed Siliciclastic-Carbonate Bone Spring Formation,

3 Permian Basin, west Texas

4

5 Wylie Walker ${ }^{1 *}$, Zane R. Jobe ${ }^{1}$, J. F. Sarg ${ }^{1}$, Lesli Wood $^{1}$

$6{ }^{1}$ Geology and Geological Engineering, Colorado School of Mines, 1600 Illinois St., Golden, CO,

$7 \quad$ United States

8 * Correspondence:

9 Wylie Walker, Encana Corporation, Denver, CO

10 wylie.walker@gmail.com

12 ABSTRACT

13 Sediment transport and partitioning are important for understanding slope-building processes in

14 mixed carbonate-siliciclastic sediment routing systems. The Permian-aged Bone Spring

15 Formation, Delaware Basin, west Texas is a mixed carbonate-siliciclastic system that has been

16 extensively studied in its basinal extent, but poorly constrained at its proximal, upper slope

17 segment. In this study, we constrain the stratigraphic architecture of the proximal Bone Spring

18 Fm. outcrops in Guadalupe Mountains National Park in order to delineate the dynamics of

19 carbonate and siliciclastic sediment delivery to the basin. These upper-slope deposits are

20 composed predominantly of fine-grained carbonate slope facies interbedded at various scales

21 with terrigenous hemipelagic and sediment gravity flow deposits. We identify ten slope-building

22 clinothems that vary from siliciclastic-rich to carbonate-rich and are truncated by slope

23 detachment surfaces that record large-scale mass-wasting of the shelf margin. X-ray fluorescence

24 (XRF) data indicates that slope detachment surfaces contain a higher-than-normal proportion of

25 terrigenous siliciclastic sediment, suggesting failure is triggered by accommodation or sediment

26 supply changes at the shelf margin. Furthermore, a well-exposed siliciclastic-rich clinothem, 
27 identified here as the $1^{\text {st }}$ Bone Spring Sand, provides evidence that carbonate and terrigenous

28 sediment were deposited contemporaneously, suggesting both autogenic and allogenic processes

29 influenced the Bone Spring Fm. stratigraphy. This mixing of lithologies at multiple scales and

30 the prevalence of mass-wasting act as a primary control on the stacking patterns of siliciclastic

31 and carbonate lithologies on not only the Bone Spring margin, but also in the distal portion of the

32 Delaware Basin.

\section{1. INTRODUCTION}

35 The dynamics of continental margin evolution and sediment partitioning impact the spatial and

36 temporal distribution of reservoir-forming elements (Saller et al., 1989; Bull et al., 2009; Playton

37 et al., 2010; Janson et al., 2011; Stevenson et al., 2015; Hurd et al., 2016; Playton and Kerans,

38 2018) and record autogenic and allogenic processes acting on the system (Shanley and McCabe,

39 1994; Covault et al., 2006; Burgess, 2016; Madof et al., 2016; Romans et al., 2016). The

40 importance of stratigraphic architecture and sediment partitioning on continental margin

41 evolution has been documented in both siliciclastic (Kertznus and Kneller, 2009; Sylvester et al.,

42 2012; Salazar et al., 2015; Stevenson et al., 2015; Prather et al., 2017) and carbonate systems

43 (Bosellini, 1984; Sonnenfeld, 1991; Kerans et al., 1993; Ross et al., 1994; Sarg et al., 1999;

44 Mulder et al., 2012). Clinothems (surface-bounded packages of sediment) in both siliciclastic

45 and carbonate systems record slope evolution and the variable distribution of lithologies (Rich,

46 1951; Mitchum et al., 1977; Vail, 1987; Sonnenfeld, 1991; Ross et al., 1994; Sarg et al., 1999;

47 Playton et al., 2010; Salazar et al., 2015). While most studies of clinothems have focused on

48 siliciclastic margins (Mitchum et al., 1977; Vail, 1987; Bull et al., 2009; Kertznus and Kneller,

49 2009; Sylvester et al., 2012; Salazar et al., 2015; Stevenson et al., 2015; Prather et al., 2017) or 
steep, reef-rimmed carbonate margins (Bosellini, 1984; Katz et al., 2010; Harman, 2011; Mulder

51 et al., 2012; Jo et al., 2015; Principaud et al., 2015; Playton and Kerans, 2018), studies of low-

52 relief, mixed siliciclastic-carbonate margins are less well documented (Saller et al., 1989; James

53 et al., 1991; Sonnenfeld, 1991; Fitchen, 1997; Grosheny et al., 2015; Tassy et al., 2015).

54 In the Permian-aged Delaware Basin of west Texas, the Victorio Peak (shelfal facies) and Bone

55 Spring (slope, basinal facies) formations represent a low-relief, mixed siliciclastic-carbonate

56 depositional system that is a prolific hydrocarbon system (Allen et al., 2013; Driskill et al., 2018;

57 Schwartz et al., 2018). Studies in the Bone Spring Fm. have focused primarily on the basinal

58 deposits, which record heterogeneity between siliciclastic and carbonate lithologies and a

59 mixture of turbidites, mass-transport deposits, and hemipelagic-pelagic deposits (Saller et al.,

60 1989; Montgomery, 1997a, 1997b; Asmus and Grammer, 2013; Nance and Rowe, 2015; Driskill

61 et al., 2018). A few studies (Kirkby, 1982; Fitchen, 1997) have focused on the shelfal (Victorio

62 Peak) deposits, documenting cyclic deposition of platform carbonates and bypassing siliciclastic

63 sands. While both the proximal and distal portions of the sediment routing system have been

64 documented, the upper slope segment of the Bone Spring Formation has only been partially

65 documented (King, 1948; McDaniel and Pray, 1967; Kirkby, 1982; Fitchen, 1997).

66 This study constrains the progradational slope architecture and the sediment partitioning of the

67 upper-slope Bone Spring deposits exposed in Guadalupe Mountains National Park, west Texas.

68 The objectives of this study are to document (1) slope-building clinothems of variable and mixed

69 lithology, (2) slope detachment surfaces that bound clinothems, and (3) abundant mass-wasting

70 deposits and their relationship to clinothems and slope detachment surfaces. We use these results

71 to speculate on slope evolution in a mixed-lithology margin, the role of mass-wasting and

72 terrigenous sediment supply in shaping the margin and delivering sediment to the basin, 
73 allogenic and autogenic forcing on sediment delivery, and how the evolution of the upper slope

74 affects the depositional processes and stacking patterns of carbonate and siliciclastic sediment in

75 the distal Delaware Basin.

\section{2. GEOLOGIC AND STRATIGRAPHIC SETTING}

\section{$78 \quad 2.1$ Geologic Setting}

79 The Bone Spring Formation was deposited in the Delaware Basin, a sub-basin of the larger

80 Permian Basin of west Texas during Leonardian time (middle Permian, 275-280 Ma; Figure 1A

81 inset). During the late-Mississippian assembly of the supercontinent Pangea ( 326 Ma), the

82 Permian Basin began to take shape as a foreland basin north of the Marathon-Ouachita-Sonora

83 orogeny (Poole et al., 2005; Figure 1A inset). Compression reactivated Precambrian areas of

84 weakness and uplifted the Central Basin Platform, creating two sub-basins of the Permian Basin,

85 the Delaware and Midland Basins (Figure 1A inset; Hills, 1984; Hill, 1996; Amerman, 2009;

86 Nance and Rowe, 2015). The Delaware Basin was bounded to the west and north by the Diablo

87 Platform and Northwest Shelf, to the south by the Marathon-Ouachita-Sonora fold belt and

88 Hovey Channel, and to the east by the Central Basin Platform and San Simon and Sheffield

89 Channels (Figure 1A inset; Asmus and Grammer, 2013). Tectonic activity occurred until at least

90 the middle Wolfcampian ( 295 Ma; Hills, 1984; Amerman, 2009) while the Leonardian stage

91 ( 285 to $275 \mathrm{Ma}$ ) was generally a quiescent tectonic environment (Hills, 1984; Amerman, 2009).

92 Subsidence related to sediment loading as well as isostatic adjustment on the basin margins

93 created a deep ( 450 meters) Delaware basin with up to 2,500 meters of Permian sediment

94 (Hills, 1984). 
95 Sediment routing into the Delaware Basin originated from the north and east (Soreghan and

96 Soreghan, 2013) with some sediment input from the Marathon-Ouachita-Sonora region to the

97 south (Hu et al., 2018; Soto-Kerans et al., 2018), where aeolian and fluvial processes delivered

98 sediment to the shelf and shelf margin (Presley, 1987; Fisher and Sarnthein, 1988). During

99 Leonardian time, especially during low sea-level conditions, the entrance to the open Panthalassa

100 Ocean to the west was restricted by a sill in the Hovey Channel (Fitchen, 1997). This sill

101 restricted water circulation in the basin, leading to euxinic basin conditions (McDaniel and Pray,

102 1967), minimal bioturbation, and the preservation of organic-rich sediment (Hills, 1984).

103

$104 \quad$ 2.2 Shelf-to-Basin Stratigraphy

105 The evolution of the shelf-margin and basinal strata that comprise the Delaware Basin are well

106 documented by King (1948), Sarg and Lehman (1986), Kerans et al. (1993), Sarg et al. (1999),

107 and Kerans and Kempter (2002). Figure 2 shows the chronostratigraphic and lithostratigraphic

108 units within the Delaware Basin that have been correlated from shelf to basin. Representing the

109 lower-most Permian-aged rock is the Wolfcamp Fm., a mixed carbonate-siliciclastic prograding

110 shelf-to-basin system (Silver and Todd 1969; Kvale and Rahman, 2016) that does not outcrop in

111 the study area (Figure 1). Overlying the Wolfcamp Fm. are Leonardian-aged prograding

112 carbonate banks to rimmed platforms with slopes of 5-20 degrees (Harris, 2000) that transition

113 into a deep basin assemblage (Figure 2; Fitchen, 1997; Asmus and Grammer, 2013; Hurd et al.,

114 2018). The Leonardian system is composed of the proximal Yeso Formation that represents a

115 restricted shelf environment with aeolian red beds and evaporitic deposits (Stanesco 1991;

116 Fitchen, 1997). The Yeso Formation transitions to the open platform Victorio Peak Formation, a

117 carbonate grain-margin (Kirkby, 1982), that transitions to the Bone Spring Formation carbonate 
118 and siliciclastic slope and basin deposits (Figure 2; Saller et al., 1989; Montgomery, 1997a;

119 Fitchen, 1997; see Figure 2). Fitchen (1997) described six third-order sequences within the

120 Victorio Peak-Bone Spring margin (L1-L6; Figure 2), where sequence boundaries represent

121 subaerial exposure on the platform and coeval sand deposition in the deep basin. Within

122 sequences are lowstand (sand-rich) and highstand to transgressive (carbonate-rich) members

123 thought to be representations of cyclicity in sea-level and basinal subsidence (Figure 2; Silver

124 and Todd, 1969; Saller et al., 1989; Fitchen, 1997; Nance and Rowe, 2015). Within each of the

125 sand-rich and carbonate-rich members, higher-order lithologic cyclicity exists in the Bone Spring

126 basinal deposits (Montgomery, 1997a; Nance and Rowe, 2015; Driskill et al., 2018) and is

127 interpreted to represent allogenic high frequency sequences (Nance and Rowe, 2015). A

128 significant erosional surface separates the Victorio Peak and Bone Spring Formations from the

129 overlying Cutoff Formation (Figure 2). This surface is known as the top of LD10 (Sarg et al.,

130 1999) or top of L6 (Fitchen, 1997; Hurd et al., 2018). The Cutoff Formation began as a lowstand

131 system that eroded parts of the Victorio Peak/Bone Spring margin before reaching a maximum

132 transgression (L8/G1) that has been biostratigraphically correlated with the Leonardian to

133 Guadalupian boundary (Hurd, 2016). Above the Cutoff Formation is the Guadalupian-aged

134 Delaware Mountain Group, including the Brushy Canyon Formation (G5-G7), which consists of

135 a submarine channel-fan system (Zelt and Rossen, 1995;1995; Gardner and Sonnenfeld, 1996;

136 Gardner et al., 2008; Figure 2). Capping the succession are Guadalupian-aged reef-rimmed

137 carbonate platforms (Capitan Formation) and their coeval basinal deposits (Figure 2; Kerans et

138 al., 1993; Harman, 2011).

139 Constraining the outcropping Victorio Peak and Bone Spring Formations in Guadalupe

140 Mountains National Park (GMNP, Figure 1) into this stratigraphic context is difficult because of 
141 paleo-erosional features (e.g. Cutoff Fm.) and poor-resolution biostratigraphy. Lithostratigraphic

142 correlations from Fitchen (1997) suggest the Victorio Peak-Bone Spring outcrops represent the

143 L5 and L6 shelf margin to upper slope sequences; this interpretation is supported by recent

144 biostratigraphic and lithostratigraphic correlations in the Cutoff Fm. (Hurd et al., 2016). To

145 complicate matters, correlating the Bone Spring Fm. outcrops to the basin can be difficult as

146 many industry naming schemes are purely lithostratigraphic (e.g., $1^{\text {st }}$ Bone Spring Sand, $1^{\text {st }}$ Bone

147 Spring Carbonate, Avalon) and biostratigraphic age control is poor in the subsurface basinal

148 deposits (Figure 2; Driskill et al., 2018; Hurd et al., 2018). Hurd et al. (2018) correlates the base

149 of the outcropping Cutoff Fm. (base L7) to the base of the Upper Avalon Shale in the basin

150 (Figure 2). Therefore, the Bone Spring Fm. outcrops in our study area likely correlate to basinal

151 rocks referred to as the Middle Avalon Carbonate, Lower Avalon Shale (boundary between L5

152 and L6), and some portion of the $1^{\text {st }}$ Bone Spring Carbonate (Figure 2).

154 3. STUDY AREA AND OUTCROP MAPPING

$155 \quad$ 3.1 Study Area

156 The study area is focused along the 'western escarpment' of GMNP (Figure 1B), a northward-

157 trending footwall fault block that was created during Cenozoic extensional tectonism (Hills,

158 1984; Hill, 1997) and exposes Leonardian and Guadalupian-aged carbonate and siliciclastic

159 shelf-margin stratigraphy (Figure 2; King, 1948; Hills, 1984; Harris, 1987). Post-depositional

160 loading (Hills, 1984), Late-Cretaceous transpression (Montgomery, 1997a), and the Cenozoic-

161 aged Huapache Monocline (Hayes, 1964; Resor and Flodin, 2010) contribute to a 2-4 eastward

162 dip of Permian rocks along the western escarpment. King (1948) extensively mapped the

163 National Park and the surrounding area, including the Bone Spring Formation that is well- 
164 exposed in a system of west-east trending canyons (Figure 1B). This study focuses primarily on

165 the outcrops in Shumard and Bone canyons, as well as the west-facing exposures between the

166 canyons (Figure 1B). Located at the entrance to Bone Canyon is the historic Williams Ranch

167 House (Figure 1B), a blue-painted homestead built in 1908.

\section{$169 \quad 3.2$ 3D Outcrop Model and Field Measurements}

170 A 3-dimensional (3D) digital outcrop model was built using Agisoft software and over 2,000

171 drone-collected photographs (Figure 3; see Supplementary Material for field-scale print). Using

172 the existing stratigraphic framework, the study area was constrained below the Cutoff Fm. and

173 down-dip of the lithostratigraphic boundary with the Lower Victorio Peak (Figure 3). Field

174 observations from bedding-attitude transects ( $N=16$ transects, $n=593$ bedding measurements),

175 nine measured sections, and six photopanel interpretations (Figures 8, 10, 12, 14, Appendix A)

176 were incorporated into the 3D model to capture depositional elements, facies relationships, and

177 prominent stratigraphic surfaces (Figure 3).

\section{$179 \quad 3.3$ Stratigraphic Surface Nomenclature and Mapping}

180 Prominent stratigraphic surfaces of various scales can be mapped throughout the outcrop (Figure

181 3). Surfaces are identified using bedding attitude changes and truncation/onlap relationships

182 (Figure 3). Large-scale surfaces are defined as those with more than $20 \mathrm{~m}$ of truncation/onlap

183 that can be mapped along the outcrop extent (kilometer-scale) before disappearing into the

184 subsurface, coalescing with another surface, or transitioning northwestward into the Victorio

185 Peak shelfal facies (black surfaces, blue numbers in Figure 3B). These large-scale surfaces are

186 interpreted as slope detachment surfaces (SDS) that may be associated with larger scale 
187 clinoform geometries. Some SDS show roll-over in the study area (SDS 4, 7, 8, 9; cf. Rich,

188 1951), suggesting these SDS have a clinoforming shape, much like the clinoforms mapped in the

189 Leonardian shelf margin by Sarg (1988) and Fitchen (1997). However, because of the limited

190 exposure of the full geometries of many of the surfaces, we refer to them as SDS. We identify

191 nine SDS and ten intervening clinothems (defined as the strata bounded by SDS) within the

192 study area (orange numbers, Figure 3B). Smaller-scale surfaces are defined as those with less

193 than $20 \mathrm{~m}$ of truncation/onlap (red lines in Figure 3B). We interpret these smaller-scale surfaces

194 as mass-wasting scars and slope failure deposits, and they occur within every clinothem (Figure $1953 B)$.

197 4. SEDIMENTARY FACIES AND DEPOSITIONAL ENVIRONMENTS

$198 \quad 4.1$ Facies

$199 \quad$ 4.1.1 Naming Schemes

200 Facies naming schemes can be difficult in mixed carbonate-siliciclastic systems because of

201 confusion between textural/compositional facies schemes (e.g., Dunham, 1962; Folk, 1980) and

202 schemes that define facies based on depositional process (e.g., Bouma, 1962; Lowe, 1982;

203 Hubbard et al., 2008). In recent years, efforts have been made to name mixed sediments focusing

204 on the mudstone dominated environments (Milliken, 2014; Lazar et al. 2015; Driskill et al.,

205 2018; Thompson et al., 2018). These naming conventions are useful in the basin setting but break

206 down as one moves up-dip along the sediment routing system into the classical carbonate realm

207 (e.g., a transition from calcareous siltstone deposited by sediment gravity flow to a lime

208 wackestone deposited on a carbonate platform). For the purposes of this paper, we developed a

209 system-scale facies scheme that is valid all along the sediment routing system (i.e. from shelf to 
210 basin) and can move along a continuum from carbonate-rich to siliciclastic-rich deposits (Figure

211 4). In our scheme, we use the historical naming convention with the highest constituent

212 component. That is, if carbonate makes up $>50 \%$ of the sediment, we use the Dunham

213 classification scheme (Dunham, 1962), and if siliciclastic and argillaceous sediment make up

$214>50 \%$ of the sediment we use the Folk classification scheme (Folk, 1954; Folk, 1980). To further

215 clarify the composition of the facies, we add a modifier if a secondary constituent makes up

216 greater than 10\% of the sediment (Chiarella and Longhitano, 2012; Lazar et al., 2015). We also

217 include a siliciclastic-carbonate ratio (s/c in Table 1) to quantify compositional variability

218 (Chiarella and Longhitano, 2012). Because most facies within the Bone Spring Formation have

219 primary sedimentary structures, we also add a modifier (e.g., 'laminated') to the facies name to

220 differentiate depositional process.

\section{4.1.2 Facies Descriptions}

223 Eight facies were identified based on composition, grain size, depositional process, bed

224 thickness, sedimentary structures, and fossil content. In addition to field-scale observations,

225 facies were constrained by thin section analysis, scanning electron microscope (SEM) analysis,

226 and X-ray fluorescence (XRF) data (Figures 4 and 5, Table 1, Appendix B). The eight facies are

227 listed below, with the dominant interpreted depositional process in parentheses based on

228 observations outlined in Table 1: 1) thin-bedded laminated lime mudstone

229 (hemipelagite/sediment gravity flow deposit); 2) thin to thick-bedded deformed lime mudstone

230 (mass-transport deposit); 3) thick-bedded bioclastic lime wackestone to packstone

231 (hemipelagite/sediment gravity flow deposit); 4) interbedded lime mudstone and bioclastic

232 packstone (interbedded hemipelagites and turbidites); 5) thick-bedded normally-graded bioclastic 
233 lime packstone to grainstone (turbidites); 6) thin-bedded laminated bioclast quartz siltstone

234 (hemipelagites and turbidites); 7) thin-bedded laminated quartz lime mudstone (hemipelagites

235 and turbidites); and 8) thick-bedded bioclastic lime packstone to grainstone (in-place shallow-

236 water carbonate platform deposits to reworked platform deposits).

237 Facies show a high degree of mixing of siliciclastic and carbonate sediment (Figure 4B).

238 Biogenic silica (i.e. chert) is abundant throughout facies and is differentiated from detrital

239 siliciclastic by a lack of clay content (cf. Driskill et al., 2018). Depositional processes also vary

240 considerably between facies (Figure 4A). The primary facies on the upper slope are carbonate-

241 dominant mudstone to wackestone facies (Facies 1, 2, 3, Figure 4A) interpreted as hemipelagic

242 and sediment gravity flow processes on the slope. Facies 1 and 2 represent a continuum of

243 deformation on the slope ranging from undeformed (Facies 1) to highly deformed (Facies 2).

244 Carbonate slope deposits are interbedded in places with coarser-grained sediment gravity flow

245 deposits (Facies 4 and 5) interpreted as calciturbidites. The carbonate-dominant facies (e.g.,

246 Facies 1) occur along a facies continuum with siliciclastic-dominant Facies 6, with Facies 7

247 representing a medial position on the carbonate-siliciclastic continuum (Figure 4C). This

248 continuum represents variable carbonate and siliciclastic compositional mixing on the shelf and

249 slope during transport (Chiarella et al., 2017). Facies 8 represents the Lower Victorio Peak of

250 King (1948) and Kirkby (1982).

251

\section{4.2 Depositional Environments}

253 Four facies associations in the outcropping Bone Spring Formation are interpreted to represent

254 sub-environments within the mixed-lithology, shelf-slope depositional system. (Figures 6, 7).

$255 \quad$ Facies Association 1 Description 
256 Facies Association 1 (FA1), includes F1, F3, and F8, with a predictable stacking pattern shown

257 in Figure 6A. F1, F3, and F8 always occur in stratigraphic sequence, with F1 at the base, F3 in

258 the middle, and F8 at the top (Figure 6A). Contacts between facies are gradational and can

259 transition over several meters (Figure 6A).

$260 \quad$ Facies Association 1 Interpretation

261 FA1 represents an upward-shoaling carbonate slope environment, with increasing grain size, bed

262 thickness, sparite and fossil content, and decreasing chert content from Facies 1 to Facies 8,

263 representing a shoaling succession from slope carbonate mudstones and turbidites to platform

264 carbonates (McDaniel and Pray, 1969). The upward-shoaling character of FA1 suggests the

265 Leonardian carbonate margin was predominantly progradational in the study area.

266 Facies Association 2 Description

267 The primary facies association, Facies Association 2 (FA2), makes up roughly 90\% of the study

268 area and includes some mixture of F1, F2, and F4 (Figures 6B, 7A, B). The F1, F2, and F4 facies

269 are interbedded and can be found transitioning laterally in a single bed-set (Figure 6B). Contacts

270 between facies can be gradational but are predominantly sharp, with truncation below and onlap

271 above the surface, particularly between F1 and F2 (Figures 6B, 7B).

272 Facies Association 2 Interpretation

273 FA2 represents a carbonate slope environment with abundant mass failure. The sharp erosional

274 surfaces found within FA2 are interpreted as slope failure scarps and/or erosional bypass

275 surfaces (Figure 7B). The lack of coarse-grained material directly mantling these surfaces

276 (Figure 7B) supports a failure scarp interpretation. These failure surfaces are often filled with a

277 wedge architectural pattern that is interpreted to be the filling of local topography. The chaotic

278 bedding and folded features found in FA2 are interpreted to be mass-failure deposits on the slope 
279 (Figure 5B, 7B). This "failure-and-fill" architecture has been well-documented in other

280 carbonate slopes (Bosellini, 1984; Ross et al., 1994; Katz et al., 2010; Playton et al., 2010;

281 Mulder et al., 2012; Playton and Kerans, 2018) as a mechanism for slopes prograding and 282 aggrading over its failed deposits.

283 Facies Association 3 Description

284 Facies Association 3 (FA3) is composed of F1, F3, F5, and F8 (Figure 6C, 7C, D). The type 285 locale of FA3 occurs on the south wall of Shumard Canyon (Figure 3), where a sharp surface 286 with $10 \mathrm{~m}$ relief truncates F3, with F5 onlapping the surface (Figure 7C). The F5 deposit is a 100 $287 \mathrm{~m}$ wide and $10 \mathrm{~m}$ thick lenticular deposit with a concave base and a flat top. Over a $10 \mathrm{~m}$ 288 interval, F5 gradually transitions into F8 (Figure 6C). Other instances of FA3 (Figure 3, 6C, 7D) 289 show similar architecture, but smaller dimensions (e.g., a $10 \mathrm{~m}$ wide and $0.5 \mathrm{~m}$ thick, lenticular 290 F5 lying above a surface that truncates F1; Figure 7D). In some instances, Facies 5 beds offset 291 stack, with fine-grained F1 draping previous deposits (Figure 7D).

\section{Facies Association 3 Interpretation}

293 FA3 is interpreted as submarine channel deposits developed in a carbonate slope setting. The 294 erosional truncation of fine-grained facies (F1, F3) and overlying coarse-grained channel fill 295 with normally graded beds (F5) indicates erosion and deposition by turbidity currents (Figure 4E, 296 7C, D; Talling et al., 2012; Janocko et al., 2013). The presence of amalgamation surfaces (Figure 297 7C) indicate multiple erosive events, suggesting that the channels were long-lived conduits for 298 sediment to the deeper basin. The presence of F8 (Lower Victorio Peak) overlying the channel 299 fill on the Shumard south wall outcrop suggests that this submarine channel was located very 300 near the shelf edge (Figure 6C). The smaller channel deposits in association with F1 are 
301 interpreted to lie in a mid-slope position and may represent slope gully deposits (Figure 6C;

302 Shumaker et al., 2016).

$303 \quad$ Facies Association 4 Description

304 Facies Association 4 (FA4) is composed of gradational interbedding of F6 and F7 (Figure 6D,

305 7E). The typical thickness of these interbeds of siliciclastic (F6) and mixed-lithology (F7) facies

306 are $\sim 10 \mathrm{~cm}$ (Figure 7E), but on the west wall of Shumard Canyon the thickness of F6 can reach

30710 meters (Figure 3). Contacts between the F6 and F7 components of FA4 are typically sharp

308 and undulatory (Figure 7E). Like FA1, FA4 contains internal truncation surfaces, with overlying

309 deformed intervals.

$310 \quad$ Facies Association 4 Interpretation

311 FA4 is interpreted as periods where more siliciclastic material was delivered to the outer

312 carbonate bank and upper slope. We interpret that this terrigenous silt-rich sediment was

313 deposited by hemipelagic and sediment gravity flow processes. The interbedded nature of F6 and

314 F7 (Figure 7E) suggests a high-frequency cyclicity in siliciclastic and carbonate deposition.

315 Deformed intervals and truncation surfaces suggest an unstable slope setting dominated by

316 failure and bypass, similar to FA2 carbonate deposits. The increased detrital siliciclastic material

317 differentiates FA4 from FA1, suggesting a change in sediment supply that affected the primary

318 slope-building facies (FA1).

320 5. STRATIGRAPHIC ARCHITECTURE

321 Six photopanels demonstrate the stratigraphic architecture of the Bone Spring Formation

322 (Figures 1B, A.1; see Supplementary Material for field-scale print). We discuss four photopanels

323 below in detail (Shumard Canyon north, Shumard Canyon south, Bone Canyon north, and Bone 
324 Canyon south). The intervening areas (west wall Shumard Canyon, west wall Bone Canyon)

325 were used to correlate between Shumard and Bone Canyons and provide additional stratigraphic 326 context and are included in Appendix A.

\subsection{Shumard Canyon}

330 The north wall of Shumard Canyon represents the best-exposed transition between the Victorio

331 Peak and Bone Spring Formations (Figure 8). Eastward and southward dipping Bone Spring

332 outcrops (F1, F2, F3) comprise most of the north wall, with flat-lying Victorio Peak Formation

333 (F8) making up the uppermost cliffs (Figure 8). Dip data show the Bone Spring Fm. slope built

334 out predominantly in an easterly direction but varies in orientation from $060^{\circ}$ to $180^{\circ}$ (Figure 8 ,

335 Figure 3A). Several areas of interest from the north wall of Shumard canyon are highlighted in

336 Figure 9. In area A, SDS 3 (Figure 9A) spans the entire height of the outcrop ( 40m relief).

337 Bedding orientation changes significantly across the surface, shifting from 18/090 (dip

338 magnitude/dip azimuth) below to 23/045 above. Above SDS 3, Clinothem 4 is characterized by

339 FA4, with siliciclastic content (F6) increasing up-section (Figure 9A). Siliciclastic-dominant

340 beds are truncated by SDS 4 , a prominent truncation surface (Figure $9 \mathrm{~A}$ ) which has $\sim 80$ meters

341 of visible relief and shows a bedding orientation change from 23/045 to 14/100. Above SDS 4 ,

342 F7 gradually transitions to F1, and FA2 characterizes Clinothem 5 and 6. Bedding orientation

343 also changes across SDS 6 (Figure 9B), with a 5-10 m thick MTD sitting directly above the

344 surface in Clinothem 7 (Figure 9B). Above SDS 7, Clinothem 8 is characterized by FA2 but

345 lacks a basal MTD (Figure 9C). However, Clinothem 8 contains many discordant surfaces (red

346 surfaces, Figure 8), one with 10-20 m of overlying F1 with a wedge geometry (Figure 9D). A 
347 prominent dip azimuth shift from due east to due south also occurs in Clinothem 8, and where

348 this change occurs, there are FA3 channel deposits (Figures 7D, 8).

\subsubsection{South Wall of Shumard Canyon}

351 SDS 3-8 and clinothem packages 4-9 can be traced from the north wall of Shumard Canyon

352 across the canyon floor to the south wall (Figure 10). The FA4-dominated Clinothem 4 continues

353 across the canyon (Figure 11C), but sand beds are thinner (cm-scale) and more interbedded with

354 Facies 7 than the deposits on the north wall. Moving up-section, Clinothems 5-7 are poorly

355 exposed but the MTD in the basal part of Clinothem 7 on the north wall of Shumard Canyon

356 (Figure 9B) can be correlated across the canyon to the south wall (Figure 10). At this locale, the

357 MTD displays decollement surfaces and compressional deformation features (Figure 11B).

358 Above SDS 7, Clinothem 8 contains a $\sim 10 \mathrm{~m}$ thick MTD (Figure 10, 11A), which was not

359 present on the north wall (Figure 8), suggesting significant parallel-to-slope heterogeneity. FA2

360 is most common on the south wall, but this locale also contains the largest submarine channel

361 deposit (FA3) in the study area (Figure 7C, Figure 10).

\section{$363 \quad 5.2$ Bone Canyon}

\section{5.2.1 North Wall of Bone Canyon}

365 The clinothems on the north wall of Bone Canyon display fewer bedding orientation changes and 366 mass wasting features (F2) than in Shumard Canyon. At the entrance to the canyon the FA4-

367 dominant Clinothem 4 is present, but the sand-rich F6 becomes progressively more

368 discontinuous from Shumard to Bone canyon (Figures 3, 12, 13A1; Figure A.3). At the mouth of 369 Bone Canyon, FA4 deposits in Clinothem 4 are offset by numerous normal faults (Figure 13A2) 
370 that are likely related to the primary Cenozoic escarpment-bounding fault (Figure 1). In

371 Clinothem 8, a small-scale discordant surface truncates F1 beds and is traceable for only $\sim 10 \mathrm{~m}$

372 laterally, with minimal dip attitude change across the surface (Figure 13C). Moving up

373 stratigraphically, SDS 8 shows the same architectural elements as in Shumard Canyon, including

374 dip attitude changes, truncation, and MTD-rich FA2 deposits (Figure 13B). In area D, SDS 9 is

375 overlain by a 20-30 m wide by $1 \mathrm{~m}$ thick submarine channel deposit (FA3; Figure 13D).

377 5.2.2 South Wall of Bone Canyon

378 The south wall of Bone Canyon displays where the Cutoff Formation truncates the Bone Spring

379 Formation with debrites composed of Victorio Peak Fm lying on the contact (Figure 14; Hurd et 380 al., 2016). Area A highlights a large ( 100 m wide x 20 m thick) wavy, deformed FA2 interval

381 with localized thrust faults (Figure 14, 15A). Individual F1 beds can be traced through the entire 382 feature and dip at greater than $40^{\circ}$ in some places. We interpret this unit of FA2 to be a slope 383 failure deposit (Figure 14, 15A). SDS 8 can be traced across Bone Canyon from the north wall 384 just beneath this MTD (Figure 14, 15B), where a $40^{\circ}$ bedding azimuth change occurs across the 385 surface (Figure 15B). In area C, SDS 9 and several overlying smaller-scale discordant surfaces 386 are identified on both canyon walls (Figure 15C). Facies 2 MTDs overlie SDS 9, and numerous 387 bedding orientation changes indicate a failure-prone Clinothem 10 (Figure 15C).

\section{FAILURE AND DEFORMATION IN THE BONE SPRING FM.}

390 The Bone Spring Fm. outcrops provide an opportunity to observe failure and deformation in a 391 mixed siliciclastic-carbonate slope environment, which has been understudied in comparison to 392 purely siliciclastic margins (cf. Moscardelli and Wood, 2016). Carbonate MTDs can act as 
393 barriers, baffles, source, and reservoirs in the Delaware Basin and elsewhere (Saller et al., 1989;

394 Allen et al. 2013; Asmus and Grammer, 2013; Thompson et al., 2017; Bhatnager et al., 2018;

395 Driskill et al., 2018). Therefore, an improved understanding of failure and deformation from the

396 outcrop can lead to better identification in core and well-logs, resulting in better reservoir

397 prediction.

398

399

\subsection{Scale of Failure and Deformation}

400 Failure and intrastratal deformation occur at many scales on the Bone Spring Fm. upper slope.

401 Most commonly, intrastratal deformation occurs on the micro-scale, typically acting on

402 individual lamina $(<1 \mathrm{~cm})$ within individual 5-20 cm thick beds (Figure 16A1, A2). Micro-scale

403 failure and intrastratal deformation is common within carbonate mudstone facies (F1, F2),

404 including slumping, water-escape, folding, imbricate stacking (cf. Auchter et al., 2016),

405 convolute bedding, micro-faults, and detachment surfaces (Figure 16A1, A2). Soft-sediment

406 deformation of similar geometry is also found on the meso-scale (1-20 meters, Figure 16B, C, D)

407 and macro-scale (>20 meters, Figure 15A). At the meso-scale, failure surfaces (red surfaces in

408 Figure 9D, Figure 13C, Figure 3) likely represent detachments for slope-attached failures

409 (Moscardelli and Wood, 2008). Meso-scale MTDs are common on the slope and consist of

410 meter-scale carbonate F1 and F2 slump and debris flow deposits (Figures 16B, C, 11B) and

411 siliciclastic slope facies (F6 and F7; Figure 16D).

412 At the macro-scale, slope detachment surfaces (SDS) can be correlated the length of the study

413 area $(>1 \mathrm{~km})$ and display minimum visible relief of 20-100 meters (Figure 3). These surfaces are

414 marked by truncation, bedding orientation changes across the surface, and a lack of karsting or

415 other evidence of subaerial exposure (Figure 9A). We interpret these surfaces to represent the 
416 evacuation scars for subaqueous mass-failures (Bosellini, 1984; Bull et al., 2009; Mazzanti and

417 De Blasio, 2010; Janson et al., 2011; Mulder et al., 2012; Principaud et al., 2015). Headwall

418 scarps from sediment evacuation on carbonate slopes often have steep angles (Mulder et al.,

419 2012; Jo et al., 2015; Principaud et al., 2015), and SDSs in the study area have structurally-

420 restored dips of 15-25 degrees. The lack of macro-scale MTDs in the study area suggests that

421 most MTDs were sourced from this steep ( 15 degrees) upper slope locale, bypassing this zone

422 and deposited more distally. This slope segmentation, with large-scale MTDs sourced in the

423 upper slope, bypassing the slope, and being deposited at the toe-of-slope or further into the basin,

424 has been documented both in the Permian Basin (Saller et al., 1989; Montgomery, 1997a; Allen

425 et al., 2013; Nance and Rowe, 2015; Bhatnager et al., 2018; Hurd et al., ,2018, Schwartz et al.,

426 2018) and in other carbonate slope systems (De Blasio et al., 2005; Moscardelli and Wood, 2008;

427 Mazzanti and De Blasio, 2010; Janson et al., 2011; Mulder et al., 2012; Dakin et al., 2013;

428 Principaud et al., 2015; Cardona et al., 2016; Moscardelli and Wood, 2016).

$430 \quad$ 6.2 Deformation Style and Character

431 Different styles of deformation provide insight into process, material strength and rheology, 432 basin orientation, and failure conditions (Figure 17; Dott, 1963; Fisher, 1983; Stow, 1986;

433 Elverhoi et al., 2000; Eyles and Eyles, 2000; Strachan, 2002; De Blasio et al., 2006; Moscardelli 434 and Wood, 2008; Tripsanas et al., 2008; Haughton et al., 2009; Mazzanti and De Blasio, 2010;

435 Talling et al., 2012; Auchter et al., 2016; Jablonska et al., 2018). Styles of intrastratal

436 deformation range from creep to slide to slump to debris flow, but often deposits reflect a

437 continuum between these styles (Figure 17; Dott, 1963; Nemec, 1990; Strachan, 2002; Tripsanas

438 et al., 2008; Haughton et al., 2009; Talling et al., 2012). Creep deposits (sensu Auchter et al., 

2016) are observed at many scales on the outcrop (Figure 17A, Figure 16A1, A2, Figure 15A)

440 and are composed primarily of carbonate mudstone facies (F1, F2, F3) that have preserved strata 441 and plastic deformation (folds, boudinage) and little to no brittle failure (Figure 17A, Dott, 1963;

442 Stow, 1986; Moscardelli and Wood, 2008; Auchter et al., 2016). A macro-scale example of creep

443 is documented from Bone Canyon south (Figure 15A), where deformed beds reach dips of $40^{\circ}$

444 with minimal intra-bed disturbance, indicating high strength and coherency of the failing rock

445 material (Dott, 1963; Stow, 1986; Elverhoi et al., 2000; Tripsanas et al., 2008; Talling et al.,

446 2012). The prevalence of multi-scale creep within the carbonate slope facies (Figure 16A1, A2)

447 suggest that the Bone Spring slope was almost always over-steepened and prone to failure (Stow, 448 1986).

449 Slide and slump deposits in the study area are composed of carbonate mudstone facies (F1, F2, 450 F3) where bedding is generally preserved (Figure 11A), but plastically deformed (folds, 451 boudinage, disrupted bedding) with minor brittle deformation (faulting, breccia; Figure 17B1, 452 B2, B3). Slump deposits often sit on basal detachment surfaces that show brecciation and 453 fracturing at the base (Figure 17B1, B2, B3; see basal shear zone, Cardona et al., in review). 454 Slumping is differentiated from creep by evidence of brittle failure and high basal shear, 455 suggesting detachment and transportation along the slope (Stow, 1986; Eyles and Eyles, 2000; 456 Strachan, 2002; Moscardelli and Wood, 2008). Deposition of slump deposits on the steep Bone 457 Spring slope indicate high material strength that prevented subsequent failure and/or 458 transformation into a debris flow (Dott, 1963; Fisher, 1983; Elverhoi et al., 2000; De Blasio et 459 al., 2006; Tripsanas et al., 2008).

460 Lastly, debris flow deposits (i.e., debrites) are composed of carbonate mudstone facies (F1, F2, 461 F3) with minimal preserved strata (Figure 16B, C, Figure 9B), a chaotic fabric with matrix 
462 supported clasts (Figure $17 \mathrm{C}, \mathrm{D}$ ), brittle deformation features (breccia, fractures; Figure 17C,

463 D), and erosional bases (Figure 17C, D), features common to debrites (Dott, 1963; Fisher, 1983;

464 Stow, 1984; Moscardelli and Wood, 2008; Tripsanas et al., 2008; Talling et al., 2012). The

465 chaotic fabric with brittle and erosional basal deformation suggests laminar flow with high basal 466 shear stresses during transport (Dott, 1963; Stow 1984; Haughton et al., 2009., Talling et al., 467 2012). Flow transformation (Fisher, 1983; Haughton et al., 2009; Talling et al., 2012) of debris

468 flows along the sediment routing system may reflect the abundance of hybrid event beds in the 469 distal Delaware basin (Driskill et al., 2018).

472 SILICICLASTIC SEDIMENT

473 The presence and partitioning of mixed sediment on the Bone Spring slope is constrained by

474 handheld XRF measurements (Figure 18). Ternary diagrams of Silicon, Calcium, and a clay-

475 proxy (Aluminum + Titanium; cf. Tribovillard et al., 2006) establish carbonate-rich and

476 siliciclastic-rich facies end-members (Figure 18). These domains are corroborated by thin

477 section, SEM, and hand sample analysis. However, biogenic silica is abundant on the Bone

478 Spring slope due to sponge spicules and radiolaria that have been diagenetically altered to chert

479 nodules and beds (Figure 7A; McDaniel and Pray, 1967). Chert beds are high in silicon and can

480 cause confusion for evaluating a terrigenous source of silica; to mitigate this, we add a trendline

481 representing a continuum from carbonate- to terrigenous-dominate environments (Figure 18).

482 Samples that plot off this trendline can be suspected of having a diagenetic component. For

483 example, some samples have high $\mathrm{Si}$ but low Ti+Al (e.g., two Facies 5 samples highlighted in

484 Figure 18), and thin section analysis (Figure 5E) reveals that these samples (1) are cemented by 
485 siliceous chert that is not derived from a terrigenous source and (2) little to no detrital siliciclastic

486 sediment present. Other XRF-based methods to distinguish biogenic silica from detrital silica

487 (e.g., $\mathrm{Si} / \mathrm{Al}, \mathrm{Zr} / \mathrm{Al}$, and $\mathrm{Zr} / \mathrm{Cr}$ ratios) have also been useful in the Bone Spring Fm. (Driskill et al., 488 2018).

489 The most common facies in the study area are carbonate mudstones (F1, F2, F4), and these facies

490 plot in the carbonate domain but with variable terrigenous input (Figure 18). Thin sections reveal

491 that a small volume $(<10 \%)$ of well-rounded, silt-sized, terrigenous, siliciclastic sediment is

492 present (Figure 4A, B), causing the variability of terrigenous material within the carbonate-

493 dominate facies. The siliciclastic sediment is interpreted to be aeolian-derived dust that was

494 transported from onshore aeolian fields (Presley, 1987; Fisher and Sarnthein, 1988; Cecil et al.,

495 2018) during high relative sea levels and high carbonate production. The siliciclastic siltstone

496 facies (F6) plot within the siliciclastic-domain (Figure 18) and are interpreted as hemipelagic and

497 sediment gravity flow processes connected to higher detrital siliciclastic sediment supply. The

498 mixed-facies (F7) plot along a continuum between the carbonate- and siliciclastic-domain and

499 represent a range of compositional mixing between F1 and F7 (Chiarella et al., 2017).

$500 \mathrm{XRF}$ transects taken across $\operatorname{SDS} 4,6,7,8$, and 9 (Figures 8 and 13) demonstrate an enrichment

501 of terrigenous sediment input associated with slope detachment surface development (Figure 19).

502 Each transect, with the exception of transect 1, begins within the mixed- or carbonate-domain

503 (circle symbols, Figure 19) and shifts toward the siliciclastic-domain at the surface (square

504 symbols). Following this shift, the transects move back into the mixed- or carbonate-domain

505 (triangle symbols). This shift occurs in every transect but each transect is positioned in different

506 parts of the calcium/silicon spectrum. Most transects (Figure 19B-E) occur within the mixed-

507 domain with a shift toward the siliciclastic-domain at the surface, while the SDS 4 transect 
508 (Figure 19A) occurs predominantly within the siliciclastic-domain. This latter transect is

509 associated with the FA4 deposits in Clinothem 4 (Figure 3, Figure 9A).

510 We interpret these results to record failure of the margin as the result of an influx of terrigenous

511 siliciclastic sediment caused by the interplay of accommodation and sediment supply (hereafter

512 referred to as A/S, cf. Shanley and McCabe, 1994). 'A' refers to accommodation that directly

513 impacts both the position of terrigenous sediment (shoreward vs basinward) and the production

514 of carbonate (e.g. high production during high accommodation). Variable progradation and

515 aggradation of carbonate sediment are captured in the ' $\mathrm{A}$ ' term (e.g. high aggradation of

516 carbonate decreases accommodation). 'S' refers to sediment supply of terrigenous sediment.

517 Because terrigenous siliciclastic sediment is associated with development of slope detachment

518 surfaces (i.e., failures), we interpret several possible mechanisms for large-scale failure: (1) an

519 increase in loading from terrigenous sediment supply (Sultan et al., 2004; Vanneste et al., 2014),

520 (2) weakened substrate from siliciclastic material (Kenter and Schlager, 1989; Kenter, 1990), (3)

521 steep relict slopes created by the carbonate-dominant environment (Schlager and Camber, 1986;

522 Ross et al., 1994). Likely a combination of all three mechanisms initiated large-scale slope

523 failure. The steep Bone Spring slope locally $\left(10-20^{\circ}\right)$ surpasses the predicted stability spectrum

524 for carbonate mudstone margins (Kenter, 1990), so the introduction of weaker siliciclastic

525 sediment onto an over-steepened carbonate slope may initiate failure. The position of four of the 526 surfaces within the mixed- to-carbonate-domain (Figure 19B-E) suggest that only a slight

527 increase in terrigenous sediment influx is necessary to trigger large-scale failure.

528 Overlying the SDS, siliciclastic sediment can occur as thin draping beds $(<5 \mathrm{~cm}$, Figures $9 \mathrm{~B}, \mathrm{C}$, 529 12B, D) with higher carbonate content (Figure 19B-E), or as meter-thick beds (Figure 9A) that 530 are carbonate poor (Figure 19A). The meter-scale siliciclastic beds may record a relatively large 
531 decrease in $\mathrm{A} / \mathrm{S}$, while thin beds record only a minor decrease in $\mathrm{A} / \mathrm{S}$. In either case, allogenic or

532 autogenic changes can produce these $\mathrm{A} / \mathrm{S}$ changes, and the result is slope failure and bypass of

533 siliciclastic sediment into the basin.

535 8. DISCUSSION

\section{$536 \quad 8.1$ Evolution of the Victorio Peak-Bone Spring Mixed Margin}

537 Outcrop observations of SDS and clinothem characteristics coupled with facies distributions aid

538 in reconstruction of the Leonardian shelf-slope profile in the study area. We use the evolution of

539 the 10 clinothem packages described above to generalize slope-building processes and sediment

540 delivery/partitioning in a mixed-lithology margin, including a 3D reconstruction of the study

541 area (Figure 20A-D) and the resulting shelf-to-basin cross-section (Figure 20E). Four possible

542 evolutionary steps are detailed (A, B, C, D), and the route the system takes through these steps

543 may vary both laterally and temporally.

544 In time step A (Figure 20A) A/S is high (i.e. A/S >1), promoting high carbonate production with

545 minimal detrital siliciclastic sediment input. Carbonate-rich hemipelagic and sediment gravity

546 flow facies (Facies 1, 2, 3, 4, 5, 8) deposit on the slope and basin with minor siliciclastic input

547 present as aeolian dust transport (Figure 18; Cecil et al., 2018). The slope builds out with

548 spatially variable progradation and aggradation, accounting for temporal changes in carbonate

549 production and along-strike variability in slope morphology (Saller et al., 1989). The dominance

550 of carbonate facies creates a relatively stable, albeit steep, environment, with minor micro-scale

551 intrastratal deformation and meso-scale slope-attached MTDs (Figure 20A; Moscardelli and

552 Wood, 2008). Clinothem packages 1-3, 5-10 (Figure 3) represent the stratigraphic record of time 553 step A. 
554 In time step B (Figure 20B) siliciclastic and argillaceous sediment supply increases, decreasing

555 A/S (e.g., A/S approaching 1), destabilizing the shelf-margin and upper slope, creating macro-

556 scale, shelf-attached failures that develop into a slope detachment surface with associated MTDs

557 (Facies 2). These SDS may be part of a larger clinoform surface. Siliciclastic sediment draping

558 surfaces indicates bypass into the basin (Facies 6 and 7, Figure 20E; Armitage et al., 2009;

559 Amerman et al., 2011; Grosheny et al., 2012). SDS 1, 2, 5-9 (Figures 3, 9B, C, 12B, D) and

560 Clinothems 1-3, 5-10 are representative of time step B (Figure 3).

561 In time step C (Figure 20C) further decrease of A/S (e.g. A/S approaching 0) introduces larger

562 volumes (relative to time step B) of siliciclastic and argillaceous material to the shelf edge and

563 slope. A clinothem is built by siliciclastic material (Facies 6), with the amount of carbonate

564 facies (Facies 7) dependent on the local carbonate production and flux of siliciclastic sediment.

565 The steep, inherited slope also promotes bypass of siliciclastic sediment into the basin (Figure

566 20E). SDS 3 and 4 and Clinothem 4 represent the outcrop expression of time step C (Figure 3).

567 In time step D (Figure 20D) A/S returns to time step A conditions. Carbonate production again

568 dominates, and the slope begins to prograde and aggrade over its failed deposits. Dip attitude

569 changes across SDS in the study area suggest a complex, 3D slope morphology as the slope

570 builds over its relict topography, perhaps with a strike-oriented lobate clinothem shape (Figures

$57122 \mathrm{C} 1, \mathrm{C} 2,8,10,12,14)$. This lobate style of progradation and aggradation on carbonate slopes

572 has been documented as a mechanism for slope building in the Bone Spring Fm. (Saller et al.,

573 1989) and in other carbonate clinoform systems (Sonnenfeld, 1991; Gomez-Perez et al., 1999;

574 Katz et al., 2010; Playton et al., 2010; Playton and Kerans, 2018). Carbonate packstone and

575 MTD facies (Facies 2, 4, 5) are common at the base of clinothems, as the relict scarp surfaces

576 attract coarse-grained sediment bypass (Eggenhuisen et al., 2010; Janson et al., 2011; Stevenson 
577 et al., 2015). Toward the top of clinothem fill, undeformed lime mudstone facies (Facies 1)

578 dominate as the slope finds local equilibrium.

579 Lobate clinothem architecture and coarse-grained bypass is demonstrated on the north wall of

580 Shumard Canyon (Figure 21). In Clinothems 1-7, bedding orientations show an easterly slope

581 progradation direction $\left(90^{\circ}\right.$, Figure 21B). At or near SDS 7 (Figure 21A), bedding orientations

582 shift to a primarily southward progradation direction $\left(180^{\circ}\right.$, Figure $\left.21 \mathrm{~B}\right)$. We interpret this

583 rotation to record a slope inflection point, where a local re-entrant may have locally focused

584 deposition (Figure 21C). A high density of slope failure surfaces and MTDs at the inflection

585 point may be related to focusing of deposition, and four submarine channel deposits are aligned

586 here (Figure 3, Figure 21A), suggesting that topographic lows created from failures may have

587 acted as conduits for coarse-grained sediment gravity flows (Figure 21C). These observations

588 suggest that the Shumard Canyon area may have been an entry point for coarse-grained sediment

589 for a portion of the northwestern Delaware Basin (Figure 1). Documentation of sediment

590 conduits in both the Cutoff (Hurd et al., 2018) and Brushy Canyon (Gardner et al., 2008)

591 formations at this location corroborate our observations of a prolonged basin entry point at this

592 location.

593 In the study area, 7 of the 9 surfaces (SDS 1, 2, 5-9) likely followed an ABD path, skipping time

594 step C and only storing siliciclastic sediment as thin bypass deposits (Figure 19B-E, Figures 9B,

595 C, 13B, D). From SDS 3 to 4, the system likely followed an ABCD path, with a high magnitude

596 decrease in A/S accounting for thicker siliciclastic beds on the slope (i.e. time step C; Figures

597 19A, 9A). A prolonged decrease in A/S (e.g. A/S 0), for example the Bone Spring $1^{\text {st }}, 2^{\text {nd }}$, and

$5983^{\text {rd }}$ Sands, would follow a similar path (i.e. ABCD), with time step C representing relatively large

599 geologic time periods and large volumes of siliciclastic sediment bypass to the basin (Stevenson 
600 et al., 2015). A schematic cross-section of this time sequence (i.e. ABDABCD) is illustrated in

601 Figure 20E.

602

\section{$603 \quad 8.2$ Implications for Sequence Stratigraphic Concepts}

604 Sequence stratigraphic concepts are commonly used for predicting facies from seismic-scale

605 geometries (Mitchum et al., 1977; Vail, 1987). However, allogenic forcing is often over-relied

606 upon without considering autogenic forcing and along-strike variability (see discussion in

607 Burgess, 2016), resulting in over-simplified stratigraphic 'pancake' models for basin fill (e.g., a

608 local sand body interpreted to represent a correlable lowstand all across a basin; Figure 22A;

609 Saller et al., 1989; Montgomery, 1997b; Crosby et al., 2017; Bhatnager et al., 2018; Schwartz et

610 al., 2018). Many studies have shown that sediment supply, accommodation, along-strike

611 variability, and many other factors affect the regional and local development of both low-order

612 and higher-order systems tracts and sequences (Covault et al., 2006; Burgess, 2016; Madof et al.,

613 2016; Harris et al., 2018; Trower et al., 2018).

614 Results from this study suggest that carbonate and siliciclastic clinothem partitioning can be

615 created by multiple forcing mechanisms. From an allogenic perspective, the siliciclastic beds

616 associated with SDS (Figures 3, 19) could record sea level fluctuations of different magnitude; in

617 this case, we would expect similar processes occurring regionally, resulting in a relatively

618 correlable basin stratigraphy (Li et al., 2015; Nance and Rowe, 2015). From an autogenic

619 perspective, variable carbonate progradation and aggradation rates result in a rugose margin

620 (Saller et al., 1989) that may provide conduits for siliciclastic sediment into the basin without

621 changing sea level. As the margin compensationally builds by growth and failure (Figure 20;

622 Saller et al., 1989; Playton et al., 2010), along-strike variability (cf. Madof et al., 2016) may 
623 result in local variability in sediment input, clinothem composition and architecture, and a highly

624 heterogeneous basin stratigraphy with contemporaneous carbonate and siliciclastic sediment

625 deposition.

626 The sand-rich clinothem documented on the outcrop (Clinothem 4, Figure 3) may provide insight

627 into this question. Based on the volume of sand deposited on the slope (Figure 3) and the high

628 enrichment of terrigenous material (Figure 19A), we interpret this clinothem to represent the

629 slope expression of the local ${ }^{\text {st }}$ Bone Spring Sand (see basin stratigraphy, Figure 2), representing

630 the base of the L5 sequence. An alternative hypothesis is that this sand-rich clinothem represents

631 a sand-body within the larger-scale prograding L5 carbonate package. Further work correlating

632 this clinothem to the shelf and the basin via biostratigraphy and well logs would provide further

633 context to this hypothesis. In either case, the disconnected architecture and interbedding with

634 carbonate facies (Figures 3, 7E, 11C, 13A1) suggests that autogenic processes are superimposed

635 onto an allogenic signal, but deconvolving those signals would be very difficult. We advise to

636 consider that both autogenic and allogenic processes contemporaneously act to build Bone

637 Spring stratigraphy, and this complexity should be considered when making local and regional

638 well correlations in the Delaware Basin and in similar mixed sediment routing systems (Figure

639 22B; Hampson, 2016; Madof et al., 2016; Romans et al., 2016).

640

641 8.3 Sub-seismic Scale Predictions from Seismic-scale Architectural Elements

642 Along strike, SDS 1-9 can be correlated for more than $1 \mathrm{~km}$ (Figure 3, 21) and have

643 relief/thickness values greater than $20 \mathrm{~m}$, indicating these are seismic-scale geometries. The

644 spatial and temporal distribution of facies and depositional elements associated with SDS show

645 how seismic-scale architecture can be used for prediction of sub-seismic-scale facies variability. 
646 Subsurface features of similar scale and architecture are imaged in seismic reflection data from

647 the Leonardian margin along the Northwest Shelf (Figure 23; Sarg, 1988, Sarg et al., 1999). A

648 seismic-scale basinal siliciclastic wedge is interpreted (labeled Lower Avalon, Figure 23B) with

649 a carbonate package prograding over the top of the sand (labeled Victorio Peak and Bone Spring

650 Carbonate, Figure 23B). Within the prograding package, clinoform geometries are identified

651 (orange lines, Figure 23B). Outcrops of the Bone Spring Fm. from this study are shown at the

652 same scale as the seismic data (Figure 23C1, C2), reinforcing the outcrop as an analog for the

653 subsurface, particularly for predicting sub-seismic-scale facies distributions. From the results in

654 this study, we expect MTDs and siliciclastic facies to onlap clinoforming slope detachment

655 surfaces at the toe-of-slope and in the basin and become progressively more carbonate-rich

656 moving stratigraphically towards the top of the clinothem (Figure 20).

\section{9. CONCLUSIONS}

659 The stratigraphic architecture of the outcropping Bone Spring Fm. of Guadalupe Mountains

660 National Park provides an opportunity to investigate slope-building processes and sediment

661 delivery in a mixed siliciclastic-carbonate margin. This dataset reveals slope-building clinothems

662 of mixed lithology bounded by slope detachment surfaces that are the result of large-scale

663 subaqueous failure of the carbonate margin. Terrigenous sediment often mantles the slope

664 detachment surfaces, suggesting that slope failure may be related to terrigenous sediment influx.

665 At the base of clinothems, carbonate mass-transport deposits (MTDs) and coarse-grained

666 carbonate allochem facies are common as the slope fills in its failed topography. At the top of

667 clinothems, undeformed carbonate mudstone facies dominate as the slope finds local

668 equilibrium. Bedding attitude data show dip azimuth changes between clinothems, suggesting 
669 that the primary mechanism for slope evolution was through compensationally-stacked lobate

670 slope-building packages. A documented slope inflection point contains abundant failures and

671 submarine channel deposits, suggesting that coarse-grained entry points to the basin are

672 influenced by slope morphology.

673 Siliciclastic-rich deposits of the Bone Spring Fm. provide insight into sequence stratigraphic

674 concepts in a mixed slope environment. A siliciclastic-rich clinothem documented in the study

675 area is interpreted as the slope equivalent of the basinal $1^{\text {st }}$ Bone Spring Sand. The nature of this

676 clinothem (e.g., interbedding with carbonate sediment, variable lateral thickness) suggests that

677 both autogenic and allogenic processes influenced deposition. Therefore, we suggest that both

678 autogenic and allogenic processes be considered concurrently when making well-to-well

679 correlations in the Delaware Basin.

680 These slope-building processes documented on the Bone Spring Fm. elucidate how mixed

681 margins evolve and act as a primary control on compositional stacking patterns and depositional

682 styles in the basin. Insight from this study can be used to reconstruct local margins and aid in

683 predicting reservoir-forming facies types in the basin.

684

685 APPENDIX

\section{Appendix A: Additional Photomosaics}

687 Additional photomosaics were compiled from the outcrop to aid in the 3D reconstruction. The 688 location of the photomosaics are shown in Figures 1B and A.1. Photopanels from the west wall

689 of Shumard Canyon (Figure A.2) and the west wall of Bone Canyon (Figure A.3) were

690 especially important for connecting Shumard and Bone Canyons and portraying the shelf-strike 691 perspective of the outcrops. 


\section{Appendix B: Extended Facies Descriptions}

$694 \quad$ Facies 1: thin-bedded laminated lime mudstone (hemipelagite/sediment gravity flow deposit)

695 Facies 1 is the primary facies present in the Bone Spring outcrop (Figure 4). The grains in this 696 facies include carbonate allochems, detrital quartz, and pyrite. These grains are surrounded by a

697 matrix composed of carbonate clay and minor argillaceous clay. The detrital siliciclastic to

698 carbonate percentage is approximately 08/92 percent. However, the s/c ratio can show variability

699 representing increasing or decreasing compositional mixing. Planar laminations can be seen on

700 the outcrop and thin section scale (Figure 5A). The planar beds alternate between dark black to

701 dark brown in the outcrop, and thin sections show that the dark black portion is composed of

702 higher proportion of clay (Figure 5A). The alternation of clay and silt layers may represent

703 segregation of grain size indicating some degree of turbulence. Some evidence of soft-sediment

704 deformation (SSD) can be found in this facies, but Facies 1 is a lower-end member of a

705 continuum with Facies 2 representing decreasing to increasing deformation on the slope (Figure

706 4A). Laterally continuous chert beds are ubiquitous in Facies 1 . These chert beds appear to be

707 cyclical and are typically 5-10 cm thick, occur approximately every $10-20 \mathrm{~cm}$, and follow

708 bedding planes. Facies 1 is interpreted to be hemipelagic and sediment gravity flow processes

709 deposited on the upper-to-middle slope.

711 Facies 2: thin to thick-bedded deformed lime mudstone (mass-transport deposit)

712 Facies 2 is identical to Facies 1 in composition, grain size, and siliciclastic to carbonate content,

713 but differs in sedimentary structures. Facies 2 represents the high-end member of the

714 deformation continuum (Figure 4A) with Facies 1. In this facies, SSD sedimentary structures 
715 such as water escape, convolute bedding, microfracturing, and folded strata (recumbent folds,

716 imbricate folds) can be identified, but in many instances, there is no distinguishable bedding (i.e.

717 chaotic bedding, Figure 5B). The prevalence of identifiable sedimentary structures and bedding

718 distinguishes the intensity of deformation experienced, with more visible and coherent bedding

719 moving toward the low-end continuum member. Chert beds typically mimic the character of the

720 bedding. In highly deformed hand samples, thin sections show a high degree of fracturing with

721 fractures filling with carbonate cement (Figure 5B). Facies 2 is interpreted to be hemipelagic and

722 sediment gravity flow slope deposits that have experienced syn- and post-deposition deformation

723 on the upper-to-middle slope.

724

725 Facies 3: thick-bedded bioclastic lime wackestone to packstone (shallow-water, reworked-

726 carbonate platform deposit)

727 Facies 3 is similar to Facies 1 and 2 in composition but differs in higher content of coarse-

728 grained bioclastic material and sparite. In this facies, crinoids, peloids, shell fragments, and

729 sponge spicules can be easily identified in outcrop (Figure 5C). Additionally, Facies 3 differs

730 from Facies 1 and 2 with less-visible sedimentary structures, lighter color, and lower frequency

731 of chert beds (approximately every $30-40 \mathrm{~cm}$ ). The lower frequency of chert beds likely indicates

732 overall thickening of beds. Chert beds may be continuous, like found in Facies 1 and 2, but are

733 more often nodular (Figure 5C). Thin sections show the coarse-grained fraction to be made up

734 very fine sand carbonate and biogenic grains (crinoids, bryozoan, brachiopods, peloids, shell

735 fragments, spicules) with minimal, if any, detrital siliciclastic grains observed (s/c ratio $<<1$;

736 5C). Facies 3 is interpreted to be hemipelagic deposits on the upper-slope. The high presence of 
737 coarse-grained bioclastic content indicates proximity to the shelf margin relative to Facies 1 and 7382.

$740 \quad$ Facies 4: interbedded lime mudstone and bioclastic packstone (interbedded hemipelagites and

741 turbidites)

742 Facies 4 is composed of two elements: a carbonate mudstone element and a bioclastic packstone

743 element (Figure 4A). The carbonate mudstone is identical to Facies 1. The bioclastic packstone

744 element is composed of coarse-grained (very fine to coarse sand) carbonate grains that are

745 mostly grain supported. Carbonate grains are composed of similar material found in Facies 1-3

746 (crinoids, brachiopods, bryozoan, spicules; Figure 5D). In the bioclastic packstone beds there is

747 evidence of cementation from calcite and dolomite (Figure 5D). The packstone beds are typically

748 on the order of $\mathrm{cm}$ - to $\mathrm{mm}$-scale and have a frequency within the lime mudstone approximately

749 every 1-2 centimeters and can be continuous, lenticular, or starved ripple beds (Figure 5D).

750 Facies 4 is interpreted to be hemipelagic slope deposits with occurrences of sediment gravity

751 flows, likely distal or low-density turbidity flows. These flows are pulses of shelfal material

752 being swept off the shelf margin onto the slope, likely from wave, storm, current, or tidal forces.

$754 \quad$ Facies 5: thick-bedded normally-graded bioclastic lime packstone to grainstone (turbidites)

755 Facies 5 is made up of approximately $85 \%$ coarse-grained sediment, typically medium to coarse 756 grain (0.5 to $1 \mathrm{~mm}$ in diameter) with some grains reaching pebble size. Grains are made up

757 entirely of carbonate or biogenic grains (siliciclastic to carbonate content, 0:100) that are

758 distinguished in hand sample and thin section as crinoids, peloids, brachiopods, bryozoan,

759 mollusks, sparite grains, sponges, and sponge spicules (Figure 5E). Thin sections reveal that 
760 there is high occurrence of sparite and siliceous chert cement (Figure 5E). The source of the

761 chert cement is from biogenic siliceous material present on the upper-slope (sponge spicules and

762 radiolarians). In some occurrences of Facies 5, chert cement has entirely replaced beds.

763 Additionally, some samples show higher degrees of sparite, ranging from $15-30 \%$ on the

764 outcrop. Fabric indicates some normal grading, but also show poorly-sorted, "patchy" beds in

765 many places (Figure 5E). Other sedimentary structures observed are low-angle scours,

766 amalgamation surfaces, styolites, and continuous red-brown colored beds. The presence of

767 grading, amalgamation surfaces, and depositional hiatuses (red surfaces) suggest these are

768 multiple carbonate sediment gravity flows, most likely turbidity current deposits (calciturbidites).

769

$770 \quad$ Facies 6: thin-bedded laminated bioclast quartz siltstone (hemipelagites and turbidites)

771 Facies 6 is similar to Facies 1 except for a higher detrital siliciclastic silt fraction (s/c $>1$, Figure

$7725 \mathrm{~F})$. This facies is made up of very fine detrital quartz and carbonate allochems set in a silt and

773 clay matrix. The matrix is dominated by siliciclastic grains and argillaceous mud (Figure 5F).

774 The ratio of siliciclastic to carbonate can vary and represents a siliciclastic-rich end member in

775 continuum with Facies 1 (Figure 4A). The increasing siliciclastic and argillaceous content

776 contributes to a noticeable lighter-brown color and different weathering pattern (Figure 5F).

777 Sedimentary structures are planar laminations to mostly a homogeneous, structureless face both

778 in outcrop and in thin section (Figure 5F). Chert is noticeably absent in this facies. Facies 6 is

779 interpreted to be siliciclastic-rich hemipelagic deposits on the upper-slope and possibly direct

780 settling of aeolian sediment blowing offshore. Facies 6 represents a clear change in

781 accommodation or sediment supply in comparison to the other hemipelagic facies (F1, F2, F3). 


\section{$783 \quad$ Facies 7: thin-bedded laminated quartz lime mudstone (hemipelagites and turbidites)}

784 Facies 7 is on a siliciclastic-to-carbonate continuum with Facies 1 and 6, representing

785 approximately a medial position between the two facies (Figure 4A). The siliciclastic-carbonate

786 ratio here is approximately 1, with about $45 \%$ siliciclastic and 55\% carbonate material (Figure

787 5G). The facies is composed of very fine detrital quartz with minimal allochems present set in a

788 carbonate mud and sparite matrix (Figure 5G). Like Facies 6, detrital quartz grains are well

789 rounded (Figure 5G) and likely represent aeolian sediment. In outcrop, minimal sedimentary

790 structures are observed but show some lamination with chert beds $5-10 \mathrm{~cm}$ thick and occur every

$791 \quad 10-20 \mathrm{~cm}$. This facies is slightly browner in color than Facies 1 but darker than Facies 6 (Figure

792 5G). Facies 7 is interpreted to be hemipelagic material with an increase in detrital influence,

793 either from aeolian settling or hemipelagic processes.

794

$795 \quad$ Facies 8: thick-bedded bioclastic lime packstone to grainstone (shallow-water carbonate

796 platform deposits)

797 Facies 8 is similar to Facies 1, 2, and 3 but shows a higher coarse-grained bioclastic content,

798 lighter color, less sedimentary structures, and thicker bedding (Figure 4A). Thin sections show

799 Facies 8 is grain supported with crinoids, bryozoan, brachiopods, peloids, sparite grains,

800 bivalves, sponges, and sponge spicules visible (Figure $5 \mathrm{H}$ ). The fine-grained fraction is entirely

801 sparite, with no carbonate mud present. Chert beds are continuous to nodular and occur

802 approximately every 0.5 to 1 meter, which is interpreted to represent higher bed thicknesses than

803 Facies 1-3. Sedimentary structures are rarely observed and have not been documented, likely

804 indicating proximity to production centers. Facies 8 is interpreted to be carbonate platform in situ

805 deposits. The higher content of bioclastic material indicates a more proximal location to the outer 
806 shelf than Facies 3 so represents the outer shelf margin environment rich in sponges, crinoids,

807 and brachiopods. Deposits were likely interacting with tidal, storm, and/or current processes.

808 This facies has been previously identified as Lower Victorio Peak by Kirkby (1982) and will be

809 considered Lower Victorio Peak for the remainder of this paper.

\section{ACKNOWLEDGMENTS}

812 We would like to thank Colorado School of Mines and the Chevron Center for Research

813 Excellence (CoRE) for providing the primary funding for this project. Additional funding was

814 provided by the West Texas Geological Society (WTGS), AAPG Grants-In-Aid, and the SEPM

815 Foundation. We would like to thank Sebastian Cardona, Evan Gross, Thomas Martin, and Enry

816 Horas Sihombing for assistance during field work and Mary Carr for providing useful feedback

817 that improved the paper.

819 REFERENCES CITED

820 Allen, J., DeSantis, J., Koglin, D. and Chen, F., 2013, Integration of structure and stratigraphy in

821 Bone Spring tight oil sandstones using 3D seismic in the Delaware Basin, TX.

822 Unconventional Resources Technology Conference, 2521-2527

823 Amerman, R., 2009, Deepwater mass-transport deposits: Structure, stratigraphy, and

824 implications for basin evolution, [PhD dissertation]: Colorado School of Mines, Golden,

825 Colorado, $152 \mathrm{p}$.

826 Amerman, R., E.P. Nelson, M.H. Gardner, and B. Trudgill, 2011, Submarine mass-transport

827 deposits of the Permian Cutoff Formation, West Texas, USA: Internal architecture and

828 controls on overlying reservoir sand deposition, in, C.R. Shipp, P. Weimer, and H.W. 
Posamentier, eds., Mass-transport deposits in deepwater settings: Society for Sedimentary Geology Special Publication 96, 235-268

831 Amitage, D.A., B.W. Romans, J.A. Covault, S.A. Graham, 2009, The influence of mass-

832 transport deposit surface topography on the evolution of turbidite architecture: the Sierra

833 Contreras, Tres Pasos Formation (Cretaceous), Southern Chile: Journal of Sedimentary

$834 \quad$ Research, v. 79, 287-301

835 Asmus, J.J., Grammer, M.G., 2013, Characterization of Deepwater Carbonate Turbidites and

836 Mass-Transport Deposits Utilizing High-Resolution Electrical Borehole Image Logs: Upper

837 Leonardian (Lower Permian) Upper Bone Spring Limestone, Delaware Basin, Southeast

838 New Mexico and West Texas: Gulf Coast Association of Geological Societies Transactions,

$839 \quad$ v. $63,27-65$

840 Auchter, N. C., Romans, B. W., \& Hubbard, S. M., 2016, Influence of deposit architecture on

841 intrastratal deformation, slope deposits of the Tres Pasos Formation, Chile: Sedimentary $842 \quad$ Geology, 341, 13-26

843 Bhatnagar, P., M., Scipione, M., Bianco, R., 2018, Characterization of mass transport deposit

$844 \quad$ using seismic attributes: Spraberry formation, Midland Basin, west Texas: SEG

$845 \quad$ International Exposition and 88th annual meeting

846 Bosellini, A., 1984, Progradation geometries of carbonate platforms: examples from the Triassic 847 of the Dolomites, northern Italy: Sedimentology, 31(1), 1-24.

848 Bouma, A.H., 1962, Sedimentology of Some Flysch Deposits: A Graphic Approach to Facies 849 Interpretation: Amsterdam Elsevier, 168 pp.

850 Bull, S., Cartwright, J. and Huuse, M., 2009, A subsurface evacuation model for submarine slope 851 failure: Basin Research, 21(4), 433-443 
852 Burgess, P. M., 2016, The future of the sequence stratigraphy paradigm: Dealing with a variable 853 third dimension: Geology, 44(4), 335-336

854 Cardona, S., L. J. Wood, R. J. Day-Stirrat, and L. Moscardelli, 2016, Fabric Development and 855 Pore-Throat reduction in a Mass-Transport Deposit in the Jubilee Gas Field, Eastern Gulf of 856 Mexico: Consequences for the Sealing Capacity of MTDs, in G. Lamarche et al., eds., 857 Submarine Mass Movements and their Consequences: Cham, Springer International Publishing, Advances in Natural and Technological Hazards Research, 27-37

859 Cardona, S., Wood, L. J., Dugan, B., Jobe, Z., \& Strachan, L. J., Characterization of the Basal 860 Shear Zone of the Rapanui Mass-Transport Deposit: Mount Messenger Formation, Taranaki 861 Basin, New Zealand: Sedimentology, (in press)

862 Cecil, C. B., Hemingway, B. S., \& Dulong, F. T., 2018, The Chemistry of Eolian Quartz Dust 863 and the Origin of Chert: Journal of Sedimentary Research, 88(6), 743-752

864 Chiarella, D., \& Longhitano, S. G., 2012, Distinguishing Depositional Environments In ShallowWater Mixed, Bio-Siliciclastic Deposits On the Basis Of The Degree Of Heterolithic

867 Chiarella, D., Longhitano, S. G., \& Tropeano, M., 2017, Types of mixing and heterogeneities in

869 Covault, J. A., Normark, W. R., Romans, B. W., \& Graham, S. A., 2007, Highstand fans in the 870 California borderland: The overlooked deep-water depositional systems: Geology, 35, 783$871 \quad 786$

872 Crosby, C. B., Pigott, J. D., \& Pigott, K. L., 2018, High resolution sequence stratigraphy of the 873 Leonardian Bone Spring Formation, northern Delaware Basin, Eddy and Lea counties, New $874 \quad$ Mexico: Search and Discovery, 51464(51464), 1-138 
875 Dakin, N., Pickering, K. T., Mohrig, D., \& Bayliss, N. J., 2013, Channel-like features created by

876 erosive submarine debris flows: Field evidence from the Middle Eocene Ainsa Basin,

877 Spanish Pyrenees: Marine and Petroleum Geology, 41(1), 62-71

878 De Blasio, F.V., Elverhøi, A., Issler, D., Harbitz, C.B., Bryn, P. and Lien, R., 2005, On the

879 dynamics of subaqueous clay rich gravity mass flows - the giant Storegga slide, Norway,

880 in Ormen Lange-an Integrated Study for Safe Field Development in the Storegga Submarine

$881 \quad$ Area: Elsevier, 179-186

882 De Blasio, F.V., Engvik, L., Harbitz, C.B., Elverhoi, A., 2006, High mobility of subaqueous

883 debris flows and the lubricating-layer model: Norwegian Journal of Geology / Norsk

$884 \quad$ Geologisk Forening, 86(3), 275-284

885 Dott, R. H., 1963, Dynamics of Subaqueous Gravity Depositional Processes: AAPG Bulletin, v. 88647, no. $1,104-128$

887 Driskill, B., Pickering, J., \& Rowe, H., 2018, Interpretation of High Resolution XRF data from

888 the Bone Spring and Upper Wolfcamp, Delaware Basin, USA, Unconventional Resources

889 Technology Conference, 2861-2888

890 Dunham, R. J., 1962, Classification of carbonate rocks according to depositional texture.

891 Classification of Carbonate Rocks: American Association of Petroleum Geologists Memoir, $892 \quad 108-121$

893 Eggenhuisen, J. T., McCaffrey, W. D., Haughton, P. D. W., Butler, R. W. H., Moore, I., Jarvie, 894 A., \& Hakes, W. G., 2010, Reconstructing large-scale remobilisation of deep-water deposits 895 and its impact on sand-body architecture from cored wells: The Lower Cretaceous Britannia 896 Sandstone Formation, UK North Sea: Marine and Petroleum Geology, 27(7), 1595-1615 
Elverhoi, A., Harbitz, C.B., Dimakis, P., Mohrig, D., Marr, J. and Parker, G., 2000. On the dynamics of subaqueous debris flows: Oceanography, 13(3), 109-117.

Eyles, C.H., Eyles, N., 2000, Subaqueous mass flow origin for Lower Permian diamictites and associated facies of the Grant Group, Barbwire Terrace, Canning Basin, Western Australia: Sedimentology, 47, 343-356

Fisher, R. V., 1983, Flow transformations in sediment gravity flows: Geology, 11(5), 273-274

Fischer, A.G., and M. Sarnthein, 1988, Airborne silts and dune-derived sands in the Permian of the Delaware Basin: Journal of Sedimentary Petrology, v. 58, 637-643

Fitchen, W.M., 1997, Lower Permian sequence stratigraphy of the western Delaware Basin Margin, Sierra Diablo, West Texas, [PhD dissertation]: University of Texas at Austin, 263 p.

Folk, R.L., 1954, The distinction between grain size and mineral composition in sedimentaryrock nomenclature: The Journal of Geology, 62(4), 344-359

Folk, R.L., 1980, Petrology of sedimentary rocks: Hemphill Publishing Company

Gardner, M. H., and M. D. Sonnenfeld, 1996, Stratigraphic changes in facies architecture of the $17-40$

915 Gardner, M.H., Borer, J.M., Romans, B.W., Baptista, N., Kling, E.K., Hanggoro, D., Melick,

916 J.J., Wagerle, R.M., Dechesne, M., Carr, M.M., Amerman, R., Atan, S., 2008, Stratigraphic

917 Models for Deep-Water Sedimentary Systems, in Answering the Challenges of Production 918 from DW Reservoirs: Analogues and Case Histories to Aid a New Generation: Gulf Coast 919 Section of SEPM Annual Conference, Houston, Texas 
920 Gómez-Pérez, I., Fernández-Mendiola, P. A., \& García-Mondéjar, J., 1999, Depositional

921 architecture of a rimmed carbonate platform (Albian, Gorbea, western Pyrenees) :

922 Sedimentology, 46(2), 337-356

923 Grosheny, D., Ferry, S., \& Courjault, T., 2015, Progradational patterns at the head of single units 924 of base-of-slope, submarine granular flow deposits ("Conglomérats des Gas”, Coniacian, SE 925 France): Sedimentary Geology, 317, 102-115

926 Hampson, G. J., 2016, Towards a sequence stratigraphic solution set for autogenic processes and 927 allogenic controls: Upper Cretaceous strata, Book Cliffs, Utah, USA: Journal of the $928 \quad$ Geological Society, 173(5), 817-836

929 Harman, C. A., 2011, Quantified Facies Distribution and Sequence Geometry of the Yates 930 Formation, Slaughter Canyon, New Mexico, [PhD dissertation]: University of Texas at $931 \quad$ Austin, $137 \mathrm{p}$.

932 Harris, M. T., 1987, Sedimentology of the Cutoff Formation (Permian), western Guadalupe 933 Mountains, west Texas: New Mexico Geology, (November), 74-79

934 Harris, M.T., 2000, Members for the Cutoff Formation, western escarpment of the Guadalupe 935 Mountains, West Texas: Smithsonian Contributions to the Earth Sciences, 32, 102-122 936 Harris, A.D., Baumgardner, S.E., Sun, T. and Granjeon, D., 2018, A poor relationship between 937 sea level and deep-water sand delivery: Sedimentary Geology, 370, 42-51

938 Haughton, P., Davis, C., McCaffrey, W., \& Barker, S., 2009, Hybrid sediment gravity flow 939 deposits - Classification, origin and significance: Marine and Petroleum Geology, 26, 1900$940 \quad 1918$

941 Hayes, P. T., 1964, Geology of the Guadalupe Mountains, New Mexico: U. S. Geological Survey 942 Professional Paper, (446), 69 pp. 
943 Hill, C.A., 1996, Geology of the Delaware Basin Guadalupe, Apache, and Glass Mountains,

944 New Mexico and West Texas: Permian Basin Section of the Society of Economic

$945 \quad$ Paleontologists and Mineralogists Publication 96-39, 480

946 Hills, J.M., 1984, Sedimentation, Tectonism, and Hydrocarbon Generation in Delaware Basin,

947 West Texas and Southeastern New Mexico: American Association of Petroleum Geologists

948 Bulletin, v. 68, No. 3 (March 1984), 250-267

949 Hu, N., D.F. Stockli, G. Sharman, H.S. Hamlin, J. Covault, 2018, Provenance of Depositional

950 Controls on Reservoir Quality of the Lower Permian (Leonardian) Spraberry Formation,

951 Midland Basin, TX, American Association of Petroleum Geologists Abstract

952 Hubbard, S. M., Romans, B. W., \& Graham, S. A., 2008, Deep-water foreland basin deposits of

953 the Cerro Toro Formation, Magallanes basin, Chile: Architectural elements of a sinuous

954 basin axial channel belt: Sedimentology, 55(5), 1333-1359

955 Hurd, G.S., 2016, Revised stratigraphic framework for the Cutoff Formation and implications for 956 deepwater systems modified by large-scale inflections in slope angle below the shelf break, 957 [PhD dissertation]: University of Texas at Austin, $275 \mathrm{p}$.

958 Hurd, G. S., Kerans, C., Fullmer, S., \& Janson, X., 2016, Large-Scale Inflections in Slope Angle 959 Below the Shelf Break: A First Order Control On the Stratigraphic Architecture of 960 Carbonate Slopes: Cutoff Formation, Guadalupe Mountains National Park, West Texas, 961 U.S.A: Journal of Sedimentary Research, 86(4), 336-362

962 Hurd, G. S., Kerans, C., Frost, E. L., Simo, J. A., \& Janson, X., 2018, Sediment gravity-flow 963 deposits and three-dimensional stratigraphic architectures of the linked Cutoff, upper Bone 964 Spring, and upper Avalon-system, Delaware Basin: AAPG Bulletin, 102(9), 1703-1737 
965 Jablonská, D., Di Celma, C. N., Alsop, G. I., \& Tondi, E., 2018, Internal architecture of mass-

966 transport deposits in basinal carbonates: A case study from southern Italy: Sedimentology, $967 \quad 65(4), 1246-1276$

968 James, N.P., Bone, Y., von der Borch, C.C., Gostin, V.A., 1992, Modern carbonate and 969 terrigenous clastic sediments on a cool water, high energy, mid-latitude shelf: Lacepede, $970 \quad$ southern Australia: Sedimentology, 39(5), 877-903

971 Janocko, M., Nemec, W., Henriksen, S., \& Warchoł, M., 2013,The diversity of deep-water 972 sinuous channel belts and slope valley-fill complexes: Marine and Petroleum Geology, $973 \quad 41(1), 7-34$

974 Janson, X., Kerans, C., Loucks, R., Marhx, M.A., Reyes, C. and Murguia, F., 2011, Seismic 975 architecture of a Lower Cretaceous platform-to-slope system, Santa Agueda and Poza Rica 976 fields, Mexico: AAPG bulletin, 95(1), 105-146

977 Jo., A., Eberli, G.P., Grasmueck, M., 2015, Margin collapse and slope failure along southwestern 978 Great Bahama Bank: Sedimentary Geology, 317, 43-52

979 Katz, D. A., Playton, T., Bellian, J., Harrison, C., \& Maharaja, A., 2010, Slope Heterogeneity 980 and Production Results in a Steep-sided Upper Paleozoic Isolated Carbonate Platform 981 Reservoir, Karachaganak Field, Kazakhstan, in SPE Caspian Carbonates Technology 982 Conference: Society of Petroleum Engineers, 1-7

983 Kenter, J., 1990, Carbonate platform flanks : slope angle and sediment fabric Carbonate 984 platforms have been the focus of increasing: Sedimentology, 37, 777-794

985 Kenter, J. A. M., \& Schlager, W., 1989, A comparison of shear strength in calcareous and 986 siliciclastic marine sediments: Marine Geology, 88(1-2), 145-152 
987 Kerans, C., Kempter, K., 2002, Hierarchical stratigraphic analysis of a carbonate platform,

988 Permian of the Guadalupe Mountains: American Association of Petroleum Geologists

989 Datapages Discovery Series, no. 5, CD ROM

990 Kerans, C., W.M. Fitchen, M.H. Gardner, and B.R. Wardlaw, 1993, A contribution to the

991 evolving stratigraphic framework of middle Permian strata of the Delaware Basin, Texas

992 and New Mexico, in, Carlsbad Region (New Mexico and West Texas), Love, D.W., Hawley,

993 J.W., Kues, B.S., Austin, G.S., Lucas, S.G., eds., New Mexico Geological Society 44th

994 Annual Fall Field Conference Guidebook, 44, 175-84

995 Kertznus, V. and Kneller, B., 2009, Clinoform quantification for assessing the effects of external

996 forcing on continental margin development: Basin Research, 21(5), 738-758

997 King, P.B., 1948, Geology of the southern Guadalupe Mountains, Texas: USGS Professional $998 \quad$ Paper 215, 183 pp.

999 Kirkby, K.C., 1982, Deposition, erosion and diagenesis of the upper Victorio Peak Formation

1000 (Leonardian), southern Guadalupe Mountains, West Texas, [MSc thesis]: Madison,

$1001 \quad$ University of Wisconsin, $165 \mathrm{p}$.

1002 Kvale, E. P., \& Rahman, M.W., 2017, Depositional Facies and Organic Content of Upper

1003 Wolfcamp Formation (Permian) Delaware Basin and Implications for Sequence Stratigraphy

1004 and Hydrocarbon Source, Unconventional Resources Technology Conference

1005 Lazar, O. R., Bohacs, K. M., Macquaker, J. H. S., Schieber, J., \& Demko, T. M., 2015, Capturing

1006 Key Attributes of Fine-Grained Sedimentary Rocks In Outcrops, Cores, and Thin Sections:

1007 Nomenclature and Description Guidelines: Journal of Sedimentary Research, 85(3), 230-

$1008 \quad 246$ 
1009 Li, S., Yu, X., Li, S., \& Giles, K. A., 2015, Role of sea-level change in deep water deposition 1010 along a carbonate shelf margin, Early and Middle Permian, Delaware Basin: implications for 1011 reservoir characterization: Geologica Carpathica, 66(2), 99-116

1012 Lowe, D.R., 1982, Sediment gravity flows: II. Depositional models with special reference to the 1013 deposits of high-density turbidity currents: Journal of Sedimentary Petrology, 52, 279-297

1014 Madof, A. S., Harris, A. D., \& Connell, S. D., 2016, Nearshore along-strike variability: Is the 1015 concept of the systems tract unhinged? : Geology, 44(4), 315-318

1016 Mazzanti P., De Blasio F.V., 2010, Peculiar Morphologies of Subaqueous Landslide Deposits 1017 and Their Relationship to Flow Dynamics. In: Mosher D.C. et al. (eds) Submarine Mass 1018 Movements and Their Consequences: Advances in Natural and Technological Hazards $1019 \quad$ Research, 28, 141-152

1020 McDaniel, P.N. and Pray, L.C., 1967, Bank to basin transition in the Permian (Leonardian) 1021 Carbonates, Guadalupe Mountains, Texas: American Association of Petroleum Geologists $1022 \quad$ Bulletin, v. 51, 474

1023 Milliken, K.L., 2014. A Compositional Classification For Grain Assemblages In Fine-Grained 1024 Sediments and Sedimentary Rocks: Journal of Sedimentary Research, 84, 1185-1199

1025 Mitchum, R. M., Vail, P. R., \& Thompson, S., 1977, Seismic Stratigraphy and Global Changes 1026 of Sea Level, Part 2: The Depositional Sequence as a Basic Unit for Stratigraphic Analysis: 1027 Section 2. Application of Seismic Reflection Configuration to Stratigraphic Interpretation. 1028 Seismic Stratigraphy: Applications to Hydrocarbon Exploration: AAPG Memoir 26, 53-62 1029 Montgomery, S.L., 1997a, Permian Bone Spring Formation: Sandstone Play in the Delaware 1030 Basin Part I: Slope: American Association of Petroleum Geologists Bulletin, v. 81, No. 8 1031 (August 2017), 1239-1258 
1032 Montgomery, S. L., 1997b, Permian Bone Spring formation: Sandstone play in the Delaware 1033 basin, part II - Basin: AAPG Bulletin, v. 81, no. 9, 1423-1434

1034 Moscardelli, L., \& Wood, L., 2008, New classification system for mass transport complexes in 1035 offshore Trinidad: Basin Research, 20(1), 73-98

1036 Moscardelli, L., \& Wood, L., 2016, Morphometry of mass-transport deposits as a predictive tool:

1037 Bulletin of the Geological Society of America, 128(1-2), 47-80

1038 Mulder, T., E. Ducassou, G. P. Eberli, V. Hanquiez, E. Gonthier, P. Kindler, M. Principaud et 1039 al., 2012, New insights into the morphology and sedimentary processes along the western 1040 slope of Great Bahama Bank: Geology, v. 40, no. 7, 603-606

1041 Nance, H.S., Rowe, H., 2015, Eustatic controls on stratigraphy, chemostratigraphy, and water 1042 mass evolution preserved in a Lower Permian mudrock succession, Delaware Basin, west 1043 Texas, USA: Interpretation, v. 3, No. 1 (February 2015), SH11-SH25

1044 Nemec, W., 1990, Aspects of sediment movement on steep delta slopes: Special Publication Int. 1045 Ass. Sed., 10, 20-73

1046 Permian Stratigraphy, Delaware to Midland Stratigraphic Correlation.

1047 https://www.sec.gov/Archives/edgar/data/1658566/000110465916143354/g155425mmi049. 1048 gif (May 2019).

1049 Playton, T.E., Janson, X., Kerans, C., James, N.P. and Dalrymple, R.W., 2010, Carbonate slopes, 1050 in James and Dalrymple 2010, Facies models 4, 449-476

1051 Playton, T. E., \& Kerans, C., 2018, Architecture and genesis of prograding deep boundstone 1052 margins and debris-dominated carbonate slopes: Examples from the Permian Capitan 1053 Formation, Southern Guadalupe Mountains, West Texas: Sedimentary Geology, 370, 15-41 
1054 Poole, F.G., Perry Jr., W.J., Madrid, R.J., Amaya-Martinez, R., 2005, Tectonic synthesis of the 1055 Ouachita-Marathon-Sonora orogenic margin of southern Laurentia: Stratigraphic and 1056 structural implications for timing of deformational events and plate-tectonic model, in, 1057 Anderson, T.H., Nourse, J.A., McKee, J.W., and Steiner, M.B., eds., The Mojave-Sonora 1058 megashear hypothesis: Development, assessment, and alternatives, Geological Society of 1059 America Special Paper 393, 543-596

1060 Prather, B. E., O’Byrne, C., Pirmez, C., \& Sylvester, Z., 2017, Sediment partitioning, continental $1061 \quad$ slopes and base-of-slope systems: Basin Research, 29 (3), 394-416

1062 Presley, M.W., 1987, Evolution of Permian evaporite basin in Texas Panhandle: American 1063 Association of Petroleum Geologists Bulletin, v. 71, 167-190

1064 Principaud, M., Mulder, T., Gillet, H., \& Borgomano, J., 2015, Large-scale carbonate submarine 1065 mass-wasting along the northwestern slope of the Great Bahama Bank (Bahamas):

1066 Morphology, architecture, and mechanisms: Sedimentary Geology, 317, 27-42

1067 Resor, P. G., \& Flodin, E. A., 2010, Forward modeling synsedimentary deformation associated 1068 with a prograding steep-sloped carbonate margin: Journal of Structural Geology, 32(9), $1069 \quad 1187-1200$

1070 Rich, J.L., 1951. Three critical environments of deposition, and criteria for recognition of rocks 1071 deposited in each of them: Geological Society of America Bulletin, 62(1), 1-20.

1072 Romans, B. W., Castelltort, S., Covault, J. A., Fildani, A., \& Walsh, J. P., 2016, Environmental 1073 signal propagation in sedimentary systems across timescales: Earth-Science Reviews, 153, $1074 \quad 7-29$ 
1075 Ross, W.C., Halliwell, B.A., May, J.A., Watts, D.E. and Syvitski, J.P.M., 1994, Slope

1076 readjustment: a new model for the development of submarine fans and

1077 aprons: Geology, 22(6), 511-514

1078 Salazar, M., Moscardelli, L., \& Wood, L., 2016, Utilising clinoform architecture to understand

1079 the drivers of basin margin evolution: a case study in the Taranaki Basin, New Zealand:

$1080 \quad$ Basin Research, 28(6), 840-865

1081 Saller, A.H., J.W. Barton, and R.E. Barton, 1989, Slope sedimentation associated with a

1082 vertically building shelf, Bone Spring Formation, Mescalero Escarpe field, southeastern

1083 New Mexico, in, P.D. Crevello, J.J. Wilson, J.F. Sarg, and J.F. Read, eds., Controls on

1084 carbonate platform and basin development, Society of Economic Paleontologists and

1085 Mineralogists, 275-288

1086 Sarg, J.F. and Lehmann, P.J., 1986, Lower-middle Guadalupian facies and stratigraphy, San

1087 Andres/Grayburg Formations, Permian Basin, Guadalupe Mountains, New Mexico, in,

1088 Moore, G.E., Wilde, G.L., and Sarg, J.F., eds., Lower and middle Guadalupian facies,

1089 stratigraphy, and reservoir geometries: San Andres/Grayburg Formations, Guadalupe

1090 Mountains, New Mexico and Texas: Society of Economic Paleontologists and

1091 Mineralogists, Permian Basin Section, Symposium and Guidebook, v. 86-25

1092 Sarg, J.F., 1988, Carbonate Sequence Stratigraphy. Sea-Level Changes - An Integrated

1093 Approach: SEPM Special Publication, 42, 155-181

1094 Sarg, J.F., Markello, J.R., Weber, L.J., 1999, The second-order cycle, carbonate-platform

1095 growth, and reservoir, source, and trap prediction: Society of Economic Paleontologists and

1096 Mineralogists Special Publication No. 63, 11-34 
1097 Schlager, W., \& Camber, O., 1986, Submarine slope angles, drowning unconformities, and self1098 erosion of limestone escarpments: Geology, 14(9), 762-765

1099 Schwartz, K.M., Meier, H., Star, A., Stolte, N., 2018, Review of the First Bone Spring Hybrid

$1100 \quad$ Play in the Delaware Basin, West Texas and Southeast New Mexico, Unconventional

$1101 \quad$ Resources Technology Conference

1102 Shanley, K. W., \& McCabe, P. J., 1994, Perspectives on the sequence stratigraphy of continental 1103 strata: American Association of Petroleum Geologists Bulletin, 78(4), 544-568

1104 Shumaker, L.E., Jobe, Z.R. and Graham, S.A., 2017, Evolution of submarine gullies on a 1105 prograding slope: Insights from 3D seismic reflection data: Marine Geology, 393, 35-46

1106 Silver, B.A., Todd, G.T., 1969, Permian Cyclic Strata, Northern Midland and Delaware Basins, 1107 West Texas and Southeastern New Mexico: American Association of Petroleum Geologists 1108 Bulletin, v. 53, No. 11 (November 1969), 2223-2251

1109 Sonnenfeld, M. D., 1991, Anatomy of offlap in a shelf-margin depositional sequence: upper San 1110 Andres Formation (Permian, Guadalupian), Last Chance Canyon, Guadalupe Mountains, 1111 New Mexico, [M.S. thesis]: Colorado School of Mines, 296 p.

1112 Soreghan, G. S., \& Soreghan, M. J., 2013, Tracing Clastic Delivery To the Permian Delaware 1113 Basin, U.S.A.: Implications For Paleogeography and Circulation In Westernmost Equatorial 1114 Pangea: Journal of Sedimentary Research, 83(9), 786-802

1115 Soto-Kerans, G.M., X. Janson, D.F. Stockli, J. Covault, 2018, Provenance Analysis of Permian 1116 (Guadalupian) Deposits: Implications for Sediment Routing and Stratal Geometry, Delaware 1117 Basin, TX: American Association of Petroleum Geologists Abstract 
1118 Stanesco, J.D., 1991, Sedimentology and depositional environments of the lower Permian Yeso

1119 Formation, northwestern New Mexico (No. 1808) : US Department of the Interior, US

1120 Geological Survey, M1-M12

1121 Stevenson, C. J., Jackson, C. A.-L., Hodgson, D. M., Hubbard, S. M., \& Eggenhuisen, J. T.,

1122 2015, Deep-Water Sediment Bypass: Journal of Sedimentary Research, 85(9), 1058-1081

1123 Stow, D.A.V., 1984, Anatomy of debris-flow deposits: Init. Rep. Deep Sea Drilling Project, 75, $1124 \quad 801-807$

1125 Stow, D. A. V., 1986, Deep clastic seas, in H. G. Reading, ed., Sedimentary Environments and 1126 Facies: Oxford, Blackwell Scientific, 399-444

1127 Strachan, L. J., 2002, Geometry to genesis: a comparative field study of slump deposits and their 1128 modes of formation: [PhD dissertation]: University of Cardiff, $409 \mathrm{p}$.

1129 Sultan, N., Cochonat, P., Canals, M., Cattaneo, A., Dennielou, B., Haflidason, H., Laberg, J.S., 1130 Long, D., Mienert, J., Trincardi, F. and Urgeles, R., 2004, Triggering mechanisms of slope 1131 instability processes and sediment failures on continental margins: a geotechnical 1132 approach: Marine Geology, 213(1-4), 291-321

1133 Sylvester, Z., Deptuck, M.E., Prather, B.E., Pirmez, C., and O’Byrne, C., 2012, Seismic 1134 stratigraphy of a shelf-edge delta and linked submarine channels in the northeastern Gulf of 1135 Mexico: Society of Economic Paleontologists and Mineralogists Special Publication No. 99, $1136 \quad 31-59$

1137 Talling, P.J., D.G. Masson, E.J. Sumner, and G. Malgesini, 2012, Subaqueous sediment density 1138 flows: Depositional processes and deposit types: Sedimentology, v. 59, 1937-2003 
1139 Tassy, A., Crouzy, E., Gorini, C., Rubino, J. L., Bouroullec, J. L., \& Sapin, F., 2015, Egyptian

1140 Tethyan margin in the Mesozoic: Evolution of a mixed carbonate-siliciclastic shelf edge

1141 (from Western Desert to Sinai): Marine and Petroleum Geology, 68(March 2018), 565-581

1142 Thompson, M., Desjardins, P., Pickering, J., Driskill, B., 2018, An Integrated View of the

1143 Petrology, Sedimentology, and Sequence Stratigraphy of the Wolfcamp Formation,

1144 Delaware Basin, Texas, Unconventional Resources Technology Conference

1145 Tribovillard. N., T.J. Algeo, T. Lyons, A. Riboulleau, 2006, Trace metals as paleoredox and

1146 paleoproductivity proxies: An update: Chemical Geology (2006), 232, 12-32

1147 Tripsanas, E.K., Piper, D.J., Jenner, K.A. and Bryant, W.R., 2008. Submarine mass-transport

1148 facies: new perspectives on flow processes from cores on the eastern North American

1149 margin: Sedimentology, 55(1), 97-136

1150 Trower, E.J., Ganti, V., Fischer, W.W. and Lamb, M.P., 2018, Erosional surfaces in the Upper

1151 Cretaceous Castlegate Sandstone (Utah, USA): Sequence boundaries or autogenic scour

1152 from backwater hydrodynamics?: Geology, 46(8), 707-710

1153 Vail, P. R., 1987, Seismic stratigraphy interpretation procedure: Atlas of Seismic Stratigraphy,

$27(2), 1-10$

1155 Vanneste, M., Sultan, N., Garziglia, S., Fredrik, C., \& Heureux, J. L., 2014, Sea floor instabilities

1156 and sediment deformation processes: The need for integrated, multi-disciplinary

1157 investigations: Marine Geology, 352, 183-214

1158 Zelt, F. B., and C. R. Rossen, 1995, Geometry and continuity of deep-water sandstones and

1159 siltstones, Brushy Canyon Formation (Permian) Delaware Mountains, Texas, in K. T.

1160 Pickering, R. N. Hiscott, N. H. Kenyon, F. Ricci-Luchi, and R. D. A. Smith, eds., Atlas of 
Deep Water Environments-Architectural Style in Turbidite Systems: Chapman and Hill, London, p. 167-183

\section{FIGURE CAPTIONS}

1165 Figure 1: Overview map of the Permian outcrops in and around Guadalupe Mountains National 1166 Park (GMNP), west Texas (modified from King, 1948). A) Geologic map of GMNP. Black box 1167 denotes Figure 1B location. White line A-A' indicates location of cross-section in Figure 2. Inset 1168 map shows Permian Basin paleogeography with GMNP denoted as a red box along the western 1169 margin of the Delaware basin, blue line indicates Figure 23 seismic line; HV = Hovey Channel,

1170 SS = San Simon Channel, $\mathrm{SH}=$ Sheffield Channel. B) Study area focusing on Leonardian-aged 1171 outcrops. Red dashed line indicates 3-D model shown in Figure 3, and red solid lines highlight 1172 interpreted outcrop exposures shown in Figures 8, 10, 12, 14, A2, and A3. Dotted tan line marks 1173 Shumard Trail.

1175 Figure 2: Stratigraphic section (A-A') of the west face of Guadalupe Mountains National Park 1176 (modified from Kerans and Kempter, 2002). This study focuses on the Bone Spring (upper slope)

1177 and Victorio Peak (outer shelf) L5 and L6 sequences (red box). Outcrop-defined sequences 1178 shown in the stratigraphic column to the left compiled from Fitchen 1997, Sarg et al., 1999, 1179 Kerans and Kempter, 2002, Hurd et al., 2016, and this study. The stratigraphic section at right 1180 defines the basin terminology with inferred chronostratigraphic correlations to outcrops. Note the 1181 Bone Spring Fm. outcrops are interpreted to correlate to the basinal rocks referred to as the

1182 Middle Avalon Carbonate, Lower Avalon Shale, and some portion of the $1^{\text {st }}$ Bone Spring 1183 Carbonate. 
1185 Figure 3: Stratigraphic Architecture of the outcropping Bone Spring Fm (see Supplementary

1186 Material for field-scale print). A) Plan view of 3D model with bedding attitudes. Contacts

1187 between Brushy Canyon, Cutoff, Upper Victorio Peak (UVP), and Lower Victorio Peak (LVP)

1188 formations shown. B) 3D digital outcrop model of the stratigraphic architecture of the Bone

1189 Spring Fm. Depositional elements, lithology variability, stratigraphic surfaces, and dip direction

1190 displayed. Ten clinothems (orange numbers) are bounded by nine slope detachment surfaces

1191 (black lines and blue numbers).

1193 Figure 4: Facies analysis of Bone Spring Fm. deposits. A) Facies diagram displaying eight

1194 facies with generalized XRF readings. Facies are grouped based on composition and depositional

1195 process. B) Ternary diagram displaying XRF data color-coded by carbonate- mixed- or

1196 siliciclastic- dominant facies (blue, orange, black, respectively). Axes truncated for detail. C)

1197 Schematic of naming scheme used in this study with facies projected.

1199 Figure 5: Facies pictures from outcrop (upper photo) and thin section (lower photo). A) Facies 1 1200 thin-bedded laminated lime mudstone. Pencil is marking ripples. Thin section of Facies 1 is 1201 predominantly lime mudstone, but detrital quartz grains are present. B) Facies 2, thin to thick1202 bedded deformed lime mudstone with lines indicating deformation. Thin section of Facies 2 with 1203 deformation-induced calcite-cemented fractures with background facies identical to Facies 1. C) 1204 Facies 3, thick-bedded bioclastic lime wackestone to packstone. Thin section of Facies 3 shows 1205 an increase in mud content to the top interpreted as possible turbidity current. D) Facies 4, 1206 interbedded lime mudstone and bioclastic packstone with interbedded packstone indicated. Thin 
1207 section shows interbedded packstone beds with calcite cementation and lenticular to continuous

1208 nature. E) Facies 5, thick-bedded normal-graded bioclastic lime packstone to grainstone. Normal

1209 grading shown with finger placed on basal coarse-grain deposit. Thin section shows bryozoan

1210 (by), brachiopods (ba), and undifferentiated carbonate allochems with chert cement. F) Facies 6,

1211 thin-bedded laminated bioclastic quartz siltstone. Note different color and weathering pattern to

1212 Facies 1. Thin section shows noticeably higher detrital quartz present in comparison to Facies 1.

1213 G) Facies 7, thin-bedded laminated quartz lime mudstone. Interbedded with Facies 6 showing

1214 different weathering pattern. Note brown color in comparison to Facies 1. Thin section of Facies

12157 with detrital quartz content less than Facies 6 but greater than Facies 1. H) Facies 8, thick-

1216 bedded bioclastic lime packstone to grainstone. Thin section of Facies 8 reveals bryozoan (by),

1217 sponge spicules (sp), rugose corals (co), brachiopods (ba), and unidentified carbonate material.

1219 Figure 6: Facies Associations of the outcropping Bone Spring Fm. A) Facies Association 1:

1220 Upward-shoaling carbonate margin. Transition from Bone Spring Fm. (BS) to Victorio Peak Fm.

1221 (VP) facies indicated. B) Facies Association 2: Carbonate slope deposits with mass wasting. C)

1222 Facies Association 3: Submarine carbonate channel deposits. Mid-slope and shelf-edge settings

1223 shown. D) Facies Association 4: Upper-slope siliciclastic-dominant hemipelagic and sediment

1224 gravity flow deposits.

1225

1226 Figure 7: Photos of Facies Associations from the outcrop. A) Facies Association 1 (FA1):

1227 undeformed prograding slope with planar chert beds (dark colored rock). B) Discordant surface

1228 within FA2; note truncation of F1, with F2 overlying the surface. C) Facies Association 3 (FA3):

1229 upper-slope submarine channel facies (F5) cutting into slope deposits (F1). Erosional surfaces 
1230 shown in yellow. D) FA3: mid-slope submarine gully deposits show offset stacking and axis-to-

1231 margin fining. E) Facies Association 4 (FA4): Interbedding of siliciclastic-rich Facies 6 (fissile,

1232 grey, recessive) and mixed-composition Facies 7 (tan colored, more resistant) on the upper slope.

1234 Figure 8: Stratigraphic Architecture of the north wall of Shumard Canyon (see Supplementary

1235 Material for field-scale print). SDS and clinothems labeled by blue and orange circles,

1236 respectively. Note the prominent dip-azimuth change in Clinothem 8 (from eastward to

1237 southward dips), coincident with a concentration of mass wasting deposits and FA3 channel

1238 deposits. Numbered inset boxes correspond to Figure 9, where siliciclastic-dominant intervals

1239 (A), mass transport deposits (B), and discordant truncation surfaces (C, D) are highlighted.

1240 Arrow symbols represent dip direction (where North is up). Compensationally stacked channels

1241 shown in Figure 7D indicated in black. Location of XRF transects 1-3 shown in blue.

1243 Figure 9: Architectural features visible on Shumard north wall. A) Prominent SDS (3 and 4)

1244 with dip attitude and lithology changes across surfaces. Above SDS 3, siliciclastic-beds dominate

1245 and are truncated by SDS 4. Figure 16D and 17A indicated in black boxes. Arrow and numerical

1246 value represent dip azimuth and magnitude; North corresponds to Figure 8. B) SDS 6 with a 5 m

1247 thick MTD sitting directly above the surface. Note debrites (db) and packstone beds (pb) with

1248 some preserved strata internally in the MTD (white lines) with the healing phase topography

1249 above the MTD. Geologist for scale. C) SDS 7 with truncation and dip attitude change in Facies

1250 1. D) Discordant surface (red) within Clinothem 8, with $\sim 15-20$ m of overlying Facies 1 with a

1251 wedge geometry. Note the geologist for scale. 
1253 Figure 10: Stratigraphic Architecture of the south wall of Shumard Canyon (see Supplementary

1254 Material for field-scale print). SDS and clinothems labeled by blue and orange circles,

1255 respectively. The large submarine channel deposit is shown in blue (see Figure 7C for details).

1256 Inset boxes correspond to Figure 11. Note that the Shumard Trail passes directly through many

1257 key architectural features.

1258

1259 Figure 11: Architectural features visible on Shumard south wall. A) Large MTD overlying SDS

1260 7. Figure 16C indicated in black box. B) MTD overlying SDS 6 shows multiple detachment

1261 surfaces (red) separating folded and faulted Facies 1 deposits. Note geologist for scale. C) FA4

1262 in Clinothem 4 consists of interbedded siliciclastic (F6) and carbonate (F7) deposits.

1263

1264 Figure 12: Stratigraphic Architecture of the north wall of Bone Canyon (see Supplementary

1265 Material for field-scale print). The Cutoff Fm. here has been eroded from the overlying Brushy

1266 Canyon Fm. channel. SDS and clinothems labeled by blue and orange circles, respectively.

1267 Numbered inset boxes correspond to Figure 13, where sand beds and normal faults (A), SDS 8

1268 (B), a 5-10-meter discordant surface (C), and a calciturbidite deposit (FA3) sitting on top of SDS

12699 are highlighted. Note vertical fractures at the eastern side of the outcrop.

1270

1271 Figure 13: Architectural features visible on Bone north wall. A1) Interbedding of siliciclastic 1272 and carbonate beds (FA4) in Clinothem 4. A2) Post-depositional faulting. Faulting shown here is

1273 small and mostly antithetic to the primary escarpment-bounding fault to the west of the outcrop

1274 (Figure 1). Geologist in circle. B) SDS 8 showing dip attitude change, truncation, and similar

1275 facies on either side of the surface. Arrow and numerical value represent dip azimuth and 
1276 magnitude; North corresponds to Figure 12. Location of XRF transect 4 (Figure 21D) shown.

1277 Symbols represent XRF readings below (circle), along (square), and above (triangle) surface. C)

1278 Example of small-scale discordant surface in red. Surface is on the meter-scale, cuts through

1279 only 1-2 beds, with minimal dip change across the surface. D) SDS 9 with a calciturbidite (FA3)

1280 sitting above the surface and a dip attitude shift from below to above. Location of XRF transect 5

1281 (Figure 21E) shown. Backpack indicated by circle.

1282

1283 Figure 14: Stratigraphic Architecture of the south wall of Bone Canyon (see Supplementary

1284 Material for field-scale print). SDS and clinothems labeled by blue and orange circles,

1285 respectively. Numbered inset boxes correspond to Figure 15, where a large mass transport

1286 deposit (A), bedding orientation change across SDS 8 (B), and SDS 9 with related mass wasting

1287 features (C) are highlighted. Figure 17B indicated. Note the Cutoff Fm. eroding into the Bone

1288 Spring Fm. (Hurd et al., 2016) and the overlying Brushy Canyon Fm. (Gardner et al., 2008).

1290 Figure 15: Architectural features visible on Bone south wall. A) Large mass transport deposit

1291 that shows minimal internal deformation other than minor folding and a soft-sediment thrust

1292 fault shown in green. Arrow and numerical value represent dip azimuth and magnitude; North

1293 corresponds to Figure 14. B) A $40^{\circ}$ dip azimuth change occurs across SDS 8, with FA2 both

1294 above and below the surface. The surface itself dips at 29/050. C) SDS 9 with overlying

1295 deformed Facies 2 MTDs, and other small-scale discordant surfaces (red surfaces) with variable

1296 F1 and F2. Note the Cutoff Fm. contact just above this surface, and the geologist for scale. 
1298 Figure 16: Scales of syn-sedimentary, intrastratal deformation observed in the Bone Spring

1299 Formation. A1) Deformed lime mudstone facies (F2) with micro-scale deformation. A2) Line

1300 drawing of figure A1. B) Meso-scale deformation. Debrite (F2) highlighted in red eroding into

1301 underlying strata. Note deformed chert beds within debrite. White lines indicate undeformed

1302 bedding below and above debrite. Location indicated in Figure 14. C) Meso-scale deformation.

1303 MTD sitting above SDS 7 erodes into underlying carbonate mudstone facies (F1). Some

1304 deformed strata and chert beds indicated by white lines. See location in Figure 11A. D) Meso-

1305 scale deformation within siliciclastic-dominant facies (F6). Deformed bedding in red with

1306 overlying undeformed bedding highlighted in white. Yellow lines indicate Cenozoic normal

1307 faults. See location in Figure 9A.

1308

1309 Figure 17: Examples of the various styles and characteristics of deformation deposits found on

1310 the Bone Spring outcrop. A) Creep deposit. Individual lamina set highlighted by white arrows

1311 shows micro-scale detachment and deformation but no failure at the bed-set $(\sim 1 \mathrm{~m})$ scale. Note

1312 chert nodules mimic the primary bedding. Location indicated in Figure 9A. Pencil circled for

1313 scale. B1) Slump deposit. Two large (meso-scale) folds separated by decollement surfaces in

1314 red. Folded bedding in white. Compressional thrust faults in yellow below first fold. Location for

1315 B2 and B3 in boxed areas. Geologist for scale. Location of fold shown in Figure A.2. B2)

1316 Breccia at the base of lower fold. Arrow and white lines indicate brecciated basal zone. B3) Thin

1317 section image near base of lower fold. Fractures in white are calcite-filled. Matrix is an F1 lime

1318 mudstone. C) Debris flow deposit (debrite). Debrite truncates underlying undeformed strata in

1319 white. Note chert and mudstone clasts within debrite. Location in area B of Shumard Cyn. south 
1320 wall. D) Debris flow deposit displaying chaotic nature of chert and carbonate mudstone matrix.

1321 Geologist pointing at large chert nodule. Location on Bone Cyn. south wall.

1323 Figure 18: Facies-based XRF results. A Calcium, Silicon, and Aluminum + Titanium ternary

1324 diagram shows a carbonate- mixed- and siliciclastic-domain that represent facies end-members

1325 in the Bone Spring Fm. A dashed line represents a continuum from the carbonate-domain to the

1326 siliciclastic-domain. Highlighted in blue, two hand samples identified as Facies 5 (i.e.

1327 calciturbidites) plot high in Silicon but deviate from the carbonate-to-siliciclastic trendline,

1328 indicating diagenetic chert present. This is confirmed in thin section (Figure 5E).

1330 Figure 19: XRF transects through Shumard and Bone canyons. Results demonstrate terrigenous 1331 sediment is associated with slope detachment surfaces. The ' $x$ ' marks the first measurement with 1332 the stratigraphic path of the transects indicated by arrows (see Figure 13). Turquoise circles mark 1333 readings of clinothems below the SDS, turquoise squares represent SDS readings, and triangles 1334 represent clinothem readings above the SDS. Blue arrows highlight transect trends; gray symbols 1335 correspond to facies in Figure 18. A) transect 1 through SDS 4. This transect is located 1336 predominantly within the siliciclastic-domain. B) transect 2 through SDS 6. Transect located 1337 within the mixed- to carbonate-domain and shifts toward the siliciclastic-domain at the surface. 1338 C-E) transects 3-5 and SDS 7-9, respectively. Surface transects show same trend as transect 2 1339 with a shift from the mixed-domain toward the siliciclastic-domain at the slope detachment 1340 surface. 
1342 Figure 20: Interpretive schematics of Leonardian margin associated with the Guadalupe

1343 Mountains National Park outcrops. A) Time step A. High A/S with high carbonate production

1344 and minimal siliciclastic input. Slope progrades and aggrades at different rates locally. B) Time

1345 step B. Detrital siliciclastic and argillaceous sediment introduced to the outer margin from a

1346 decrease in A/S. The increase in siliciclastic material weakens the slope and creates large-scale,

1347 shelf-attached failure. Large-scale failure creates slope detachment surfaces that are likely part of

1348 a larger clinoform surface (magenta surface). Surfaces are coeval with MTDs at the toe-of-slope

1349 and in the basin. C) Time step C. Further A/S decrease introduces large volumes of siliciclastic

1350 sediment to the outer margin and upper slope. Continued surface development as siliciclastic and

1351 argillaceous sediment bypass to the basin. D) Time step D. Return to high A/S with the slope

1352 prograding and aggrading over its relict topography creating a new clinothem. E) Schematic

1353 shelf-to-basin cross-section based on the slope reconstructions representing an ABDABCD time

1354 sequence. Red surfaces represent slope detachment surfaces and corresponding time-lines similar

1355 to those documented on the outcrop. The transitioning facies of Facies 5, 6, and 7 represent the

1356 expected proximal to distal transition. Red box represents outcrop-constrained portion of the

1357 schematic.

1359 Figure 21: Slope inflection points may act as conduits for coarse-grained sediment. A) Line

1360 drawing of Shumard north wall (Figure 8) with dip azimuth readings (north is up). Orange

1361 arrows represent dip readings within Clinothems 1-7, while blue arrows represent readings in

1362 Clinothem 8. Note the calciturbidites and red discordant surfaces become more common near

1363 SDS 7. The large submarine channel deposit on Shumard south wall (Figure 10) also aligns with

1364 this region. B) Bedding attitude data from Shumard north wall. Colors correspond to location on 
1365 Figure A. Average dip azimuth shifts 90 degrees after SDS 7. C) Schematic of Shumard north 1366 wall with a local inflection point in the slope. This inflection point creates instability from over1367 sedimentation and the resultant failure scarps act as a conduits for coarse-grained turbidites to the 1368 basin.

1370 Figure 22: Well-log correlations in the Permian Basin. A) 'Pancake model' interpretation of 1371 Bone Spring Fm. members in the Delaware and Midland Basins. Note that the shale and sand 1372 members of the Bone Spring are interpreted to be correlable across the entire Delaware Basin. 1373 Digital image from the web (Permian Stratigraphy). B) Alternative interpretation based on the 1374 results in this study. Note there is higher-order packages of high net-to-gross (N:G) sand and

1375 carbonate, but internally these members are heterogeneous with siliciclastic and carbonate 1376 sedimentation occurring simultaneously. Additionally, the Midland and Delaware Basins are not 1377 correlated, as they have different fill histories (Sarg, 1988, Sarg et al., 1999).

1379 Figure 23: Predicting sub-seismic facies types from seismic-scale architecture. A) Unedited 1380 seismic line of the Delaware Basin shelf margin from Sarg (1988) and Sarg et al. (1999).

1381 Location shown in Figure 1A inset. Red box indicates location of part B. B) Interpreted seismic 1382 section of Leonardian and Guadalupian shelf-to-basin stratigraphy. The unit labeled Bone Spring 1383 Carbonate would roughly correlate to the upper section (L6) of the Bone Spring outcrops in the 1384 study area. Orange lines highlight clinoform geometries within the prograding carbonate 1385 package. The Lower Avalon represents a basinal siliciclastic wedge between L5 and L6 (Figure 1386 2). C1) Photo and C2) line drawing of Shumard north, highlighting the similarity of scale and 1387 geometry of clinoforms to those seen in seismic. 
1389 Figure A.1: Location of six photopanels compiled along the outcrop shown here overlaying the 1390 3D textured model.

1391

1392 Figure A.2: West wall of Shumard Canyon photopanel. Location of figures in text indicated. See 1393 Supplementary Material for field-scale print.

1394

1395 Figure A.3: West wall of Bone Canyon photopanel. Location of figures in text indicated. See 1396 Supplementary Material for field-scale print. 
Table 1. Summary of descriptions and interpretations of lithofacies

\begin{tabular}{|c|c|c|c|c|c|c|c|c|}
\hline Facies & $\begin{array}{c}\text { Basin } \\
\text { Naming } \\
\text { Scheme } \\
\text { (Lazar et } \\
\text { al., 2015) }\end{array}$ & $\begin{array}{c}\text { Mud } \\
\text { Content } \\
\text { Silt/clay } \\
\text { type }\end{array}$ & $\begin{array}{c}\text { Coarse- } \\
\text { grain \% } \\
\text { Size } \\
\text { Type }\end{array}$ & $\begin{array}{l}\mathrm{Si} / \mathrm{Ca} \\
\text { ratio } \\
(\mathrm{s} / \mathrm{c})\end{array}$ & $\begin{array}{l}\text { Sedimentary } \\
\text { Structures }\end{array}$ & $\begin{array}{l}\text { Diagenetic } \\
\text { Features }\end{array}$ & $\begin{array}{l}\text { Depositional } \\
\text { Process }\end{array}$ & $\begin{array}{l}\text { Depositional } \\
\text { Environment }\end{array}$ \\
\hline $\begin{array}{l}\text { F1 } \\
\text { Thin- } \\
\text { bedded } \\
\text { laminate } \\
\text { lime } \\
\text { mudstone } \\
\text { (Figure 5A) }\end{array}$ & $\begin{array}{l}\text { Laminate } \\
\text { calcareous } \\
\text { siltstone }\end{array}$ & $\begin{array}{l}75-80 \% \\
60 / 40 \\
\text { Carbonate } \\
\text { clay, } \\
\text { argillaceous } \\
\text { clay, } \\
\text { carbonate } \\
\text { grains, qz } \\
\text { grains, } \\
\text { organic } \\
\text { matter, } \\
\text { pyrite }\end{array}$ & $\begin{array}{l}20-25 \% \\
\text { vfs } \\
\text { Carbonate } \\
\text { and biogenic } \\
\text { grains, } \\
\text { crinoids, } \\
\text { spicules, } \\
\text { shell } \\
\text { fragments, } \\
\text { quartz }\end{array}$ & $\begin{array}{l}08 / 92 \\
s / c<<1\end{array}$ & 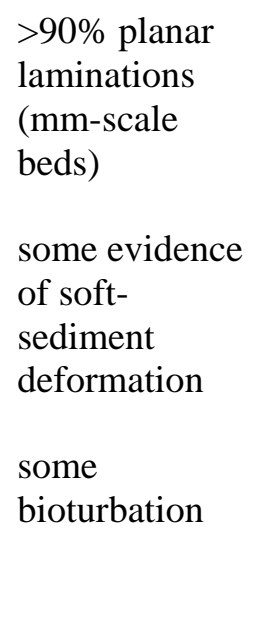 & $\begin{array}{l}\text { Chert beds } \\
\text { mostly planar } \\
(5-10 \mathrm{~cm} \\
\text { thick) or } \\
\text { nodular, } \\
\text { occurring } \\
\text { every } 10-20 \\
\mathrm{~cm} \\
\text { Minor } \\
\text { dolomitization } \\
\text { Pyrite } \\
\text { formation }\end{array}$ & $\begin{array}{l}\text { Hemipelagic } \\
\text { and sediment } \\
\text { gravity flow }\end{array}$ & $\begin{array}{l}\text { Hemipelagic } \\
\text { deposits on the } \\
\text { upper-slope } \\
\text { with sediment } \\
\text { gravity flow } \\
\text { common }\end{array}$ \\
\hline $\begin{array}{l}\mathrm{F} 2 \\
\text { Thin to } \\
\text { thick- } \\
\text { bedded } \\
\text { deformed } \\
\text { lime } \\
\text { mudstone } \\
\text { (Figure 5B) }\end{array}$ & $\begin{array}{l}\text { Deformed } \\
\text { calcareous } \\
\text { siltstone }\end{array}$ & $\begin{array}{l}75-80 \% \\
60 / 40 \\
\text { Carbonate } \\
\text { clay, } \\
\text { argillaceous } \\
\text { clay, } \\
\text { carbonate } \\
\text { grains, qz } \\
\text { grains, } \\
\text { organic }\end{array}$ & $\begin{array}{l}20-25 \% \\
\text { vfs } \\
\text { Carbonate } \\
\text { and biogenic } \\
\text { grains, } \\
\text { crinoids, } \\
\text { spicules, } \\
\text { shell } \\
\text { fragments, }\end{array}$ & $\begin{array}{l}08 / 92 \\
s / c<<1\end{array}$ & $\begin{array}{l}\text { Planar } \\
\text { laminations } \\
\text { Soft-sediment } \\
\text { deformation: } \\
\text { folding, } \\
\text { fractures, } \\
\text { fluid-escape, } \\
\text { decollement } \\
\text { surfaces } \\
\text { Chaotic }\end{array}$ & $\begin{array}{l}\text { Chert beds } \\
\text { mimic bedding } \\
\text { structure and } \\
\text { can be folded, } \\
\text { deformed, } \\
\text { nodular, or } \\
\text { planar } \\
\text { Calcite-filled } \\
\text { fractures } \\
\text { Minor }\end{array}$ & $\begin{array}{l}\text { Hemipelagic } \\
\text { deposition } \\
\text { with soft } \\
\text { sediment } \\
\text { deformation, } \\
\text { slope creep, } \\
\text { sediment } \\
\text { gravity flow }\end{array}$ & $\begin{array}{l}\text { Hemipelagic } \\
\text { and sediment } \\
\text { gravity flow } \\
\text { slope deposits } \\
\text { that have } \\
\text { undergone } \\
\text { deformation } \\
\text { from high slope } \\
\text { angles and/or } \\
\text { high sediment } \\
\text { supply }\end{array}$ \\
\hline
\end{tabular}




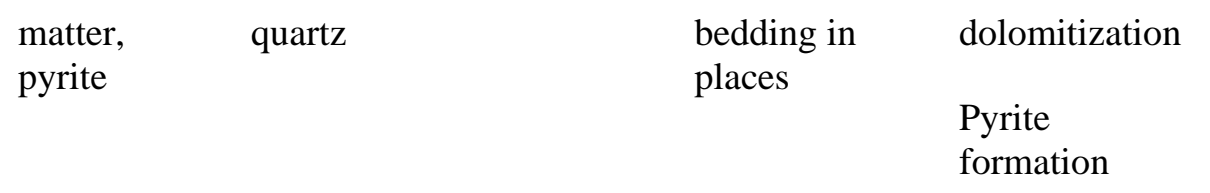

\begin{tabular}{|c|c|c|c|c|c|c|c|c|}
\hline $\begin{array}{l}\text { F3 } \\
\text { Thick- } \\
\text { bedded } \\
\text { bioclastic } \\
\text { lime } \\
\text { wackestone } \\
\text { to } \\
\text { packstone } \\
\text { (Figure 5C) }\end{array}$ & $\begin{array}{l}\text { Thick- } \\
\text { bedded } \\
\text { bioclastic } \\
\text { lime } \\
\text { siltstone to } \\
\text { very fine } \\
\text { sandstone }\end{array}$ & $\begin{array}{l}30 \% \\
70 / 30 \\
\text { Carb. and } \\
\text { arg. clay, } \\
\text { carbonate } \\
\text { grains, qz } \\
\text { grains, } \\
\text { organic } \\
\text { matter, } \\
\text { pyrite } \\
\text { 50\% mud } \\
50 \% \text { sparite }\end{array}$ & $\begin{array}{l}70 \% \\
\text { vfs } \\
\text { carbonate } \\
\text { and biogenic } \\
\text { grains, } \\
\text { peloids, } \\
\text { spicules, } \\
\text { crinoids, } \\
\text { shell } \\
\text { fragments, } \\
\text { bryozoan, } \\
\text { brachiopods, } \\
\text { qz grains }\end{array}$ & $\begin{array}{l}5 / 95 \\
\mathrm{~s} / \mathrm{c}<<1\end{array}$ & $\begin{array}{l}\text { Grading } \\
\text { Laminations } \\
\text { Some in-place } \\
\text { production }\end{array}$ & $\begin{array}{l}\text { Chert beds } \\
\text { mostly nodular } \\
(5-10 \mathrm{~cm} \\
\text { thick), } \\
\text { occurring } \\
\text { every } 30-40 \\
\mathrm{~cm}\end{array}$ & $\begin{array}{l}\text { Hemipelagic } \\
\text { and sediment } \\
\text { gravity flow }\end{array}$ & $\begin{array}{l}\text { Hemipelagic } \\
\text { slope deposits } \\
\text { that are } \\
\text { proximal to the } \\
\text { shelf margin } \\
\text { relative to F1 } \\
\text { and F2 and } \\
\text { have } \\
\text { experienced } \\
\text { reworking from } \\
\text { tidal, storm, or } \\
\text { current forces }\end{array}$ \\
\hline $\begin{array}{l}\text { F4 } \\
\text { Interbedded } \\
\text { lime } \\
\text { mudstone } \\
\text { and } \\
\text { bioclastic } \\
\text { packstone } \\
\text { (Figure 5D) }\end{array}$ & $\begin{array}{l}\text { Interbedded } \\
\text { calcareous } \\
\text { siltstone } \\
\text { and } \\
\text { bioclastic } \\
\text { very fine } \\
\text { sandstone }\end{array}$ & $\begin{array}{l}70 \% \\
\text { Same as } \\
\text { Facies } 1\end{array}$ & $\begin{array}{l}30 \% \\
\text { vfs } \\
\text { Crinoids, } \\
\text { spicules, } \\
\text { peloids, } \\
\text { shell } \\
\text { fragments }\end{array}$ & $\begin{array}{l}08 / 92 \\
\text { s/c }<<1\end{array}$ & $\begin{array}{l}\text { Packstone } \\
\text { beds occur } \\
\text { every } 1-2 \mathrm{~cm} \\
\text { and are planar } \\
\text { and } \\
\text { continuous or } \\
\text { lenticular } \\
\text { Starved } \\
\text { ripples } \\
\text { Some } \\
\text { bioturbation }\end{array}$ & $\begin{array}{l}\text { Significant } \\
\text { dolomitization } \\
\text { and calcite } \\
\text { cement in } \\
\text { packstone } \\
\text { beds }\end{array}$ & $\begin{array}{l}\text { Hemipelagic } \\
\text { deposition } \\
\text { interbedded } \\
\text { with } \\
\text { sediment } \\
\text { gravity flows } \\
\text { (turbidity } \\
\text { currents) }\end{array}$ & $\begin{array}{l}\text { Slope sheet } \\
\text { deposits of } \\
\text { coarse-grained } \\
\text { material } \\
\text { (turbidites) } \\
\text { coming off the } \\
\text { shelf onto } \\
\text { hemipelagic } \\
\text { slope deposits }\end{array}$ \\
\hline
\end{tabular}




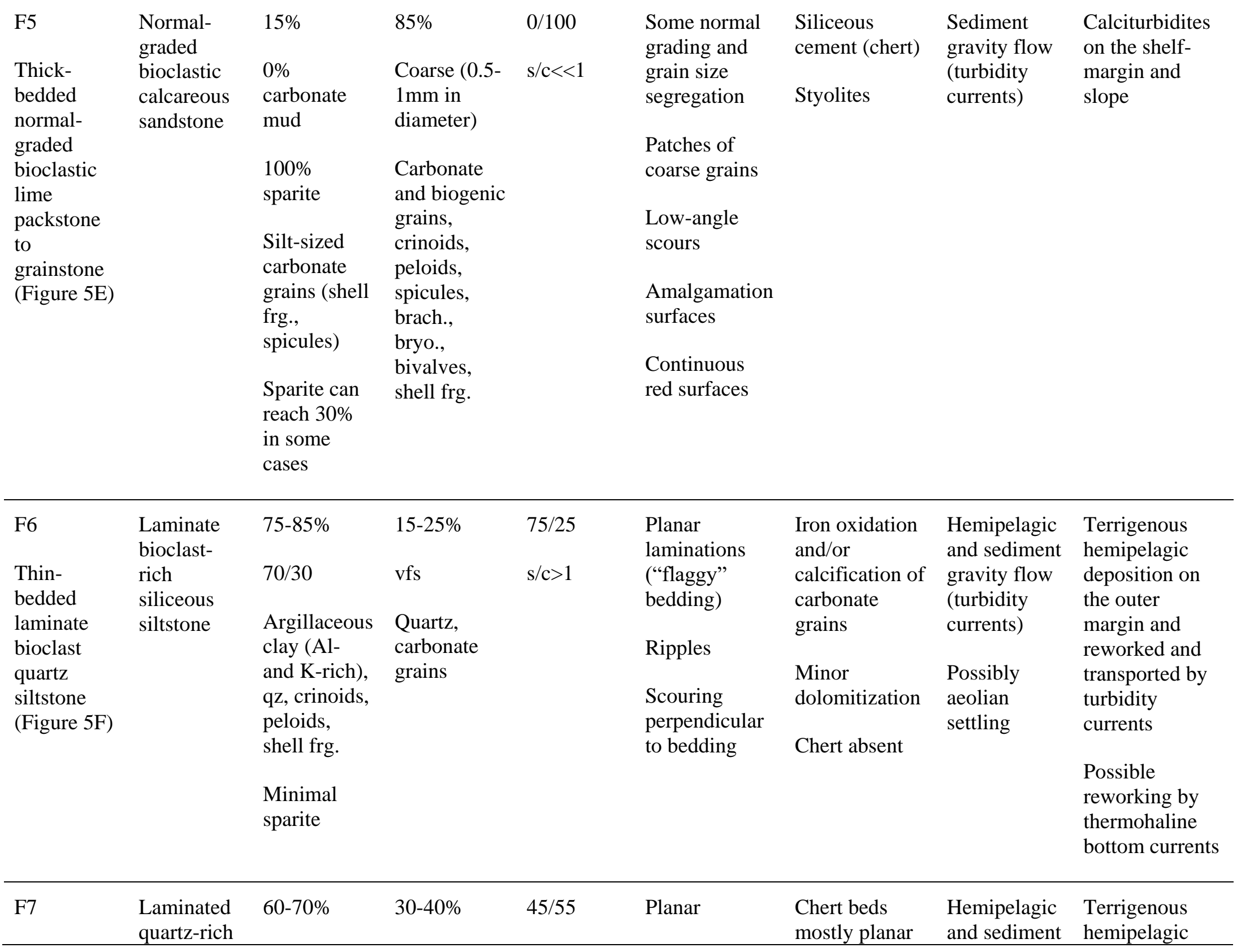




\begin{tabular}{|c|c|c|c|c|c|c|c|c|}
\hline $\begin{array}{l}\text { Thin- } \\
\text { bedded } \\
\text { laminated } \\
\text { quartz lime } \\
\text { mudstone } \\
\text { (Figure 5G) }\end{array}$ & $\begin{array}{l}\text { calcareous } \\
\text { siltstone }\end{array}$ & $\begin{array}{l}50 \% \text { mud } \\
\text { and silt } \\
50 \% \text { sparite }\end{array}$ & $\begin{array}{l}\text { vfs } \\
\text { Some fs } \\
\text { Mostly qz, } \\
\text { some shell } \\
\text { frg. }\end{array}$ & $\mathrm{s} / \mathrm{c} \sim 1$ & $\begin{array}{l}\text { laminations } \\
\text { Scouring } \\
\text { perpendicular } \\
\text { to bedding } \\
\text { Minor soft- } \\
\text { sediment } \\
\text { deformation }\end{array}$ & $\begin{array}{l}(5-10 \mathrm{~cm} \text { thick }) \\
\text { or nodular, } \\
\text { occurring } \\
\text { every } 10-20 \\
\mathrm{~cm} \\
\text { Minor } \\
\text { dolomitization }\end{array}$ & $\begin{array}{l}\text { gravity flow } \\
\text { (turbidity } \\
\text { currents) } \\
\text { Possibly } \\
\text { aeolian } \\
\text { settling }\end{array}$ & $\begin{array}{l}\text { deposition } \\
\text { compositionally } \\
\text { mixing with } \\
\text { carbonate } \\
\text { material on the } \\
\text { outer margin } \\
\text { and reworked } \\
\text { and transported } \\
\text { by turbidity } \\
\text { currents } \\
\text { Possible } \\
\text { reworking by } \\
\text { thermohaline } \\
\text { bottom currents }\end{array}$ \\
\hline
\end{tabular}



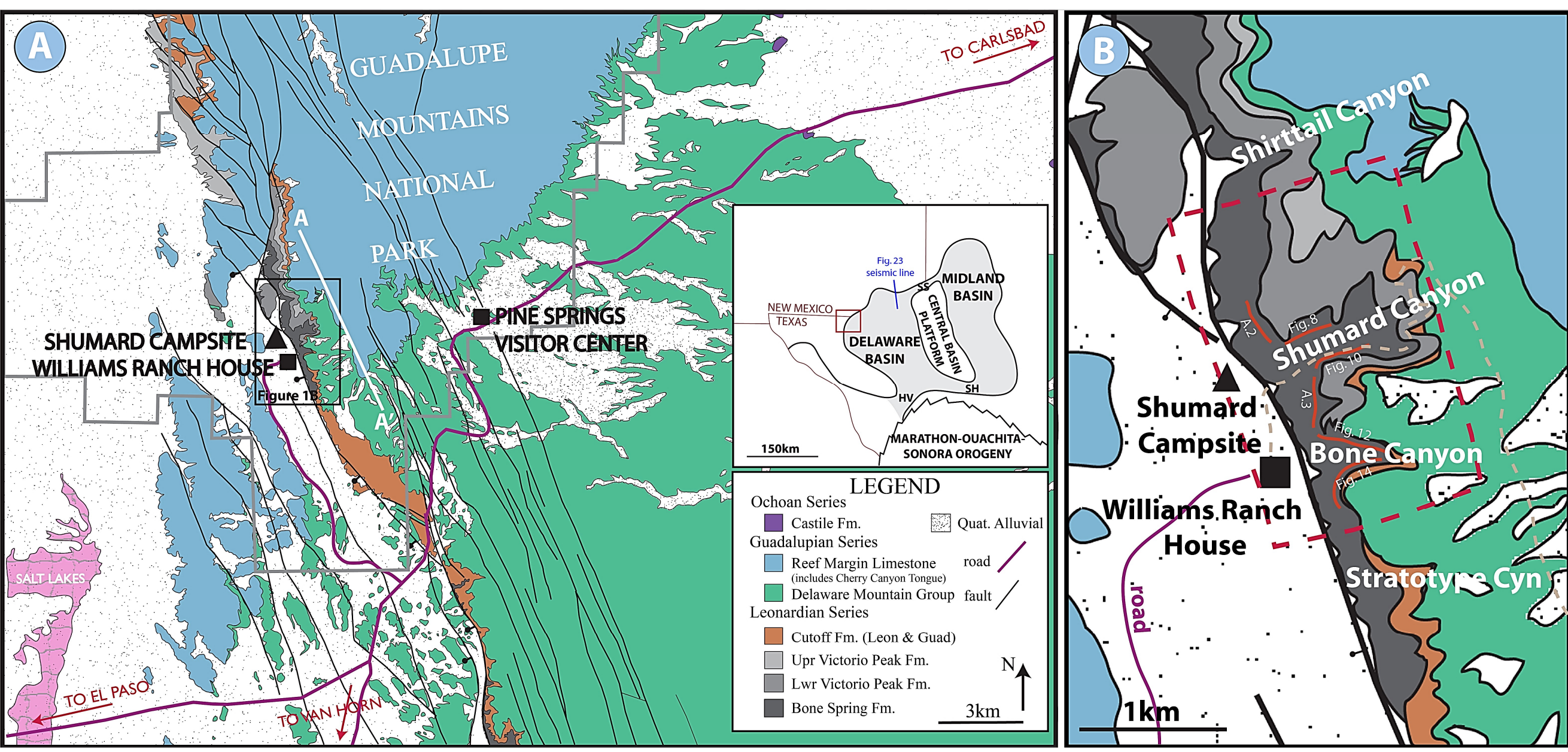


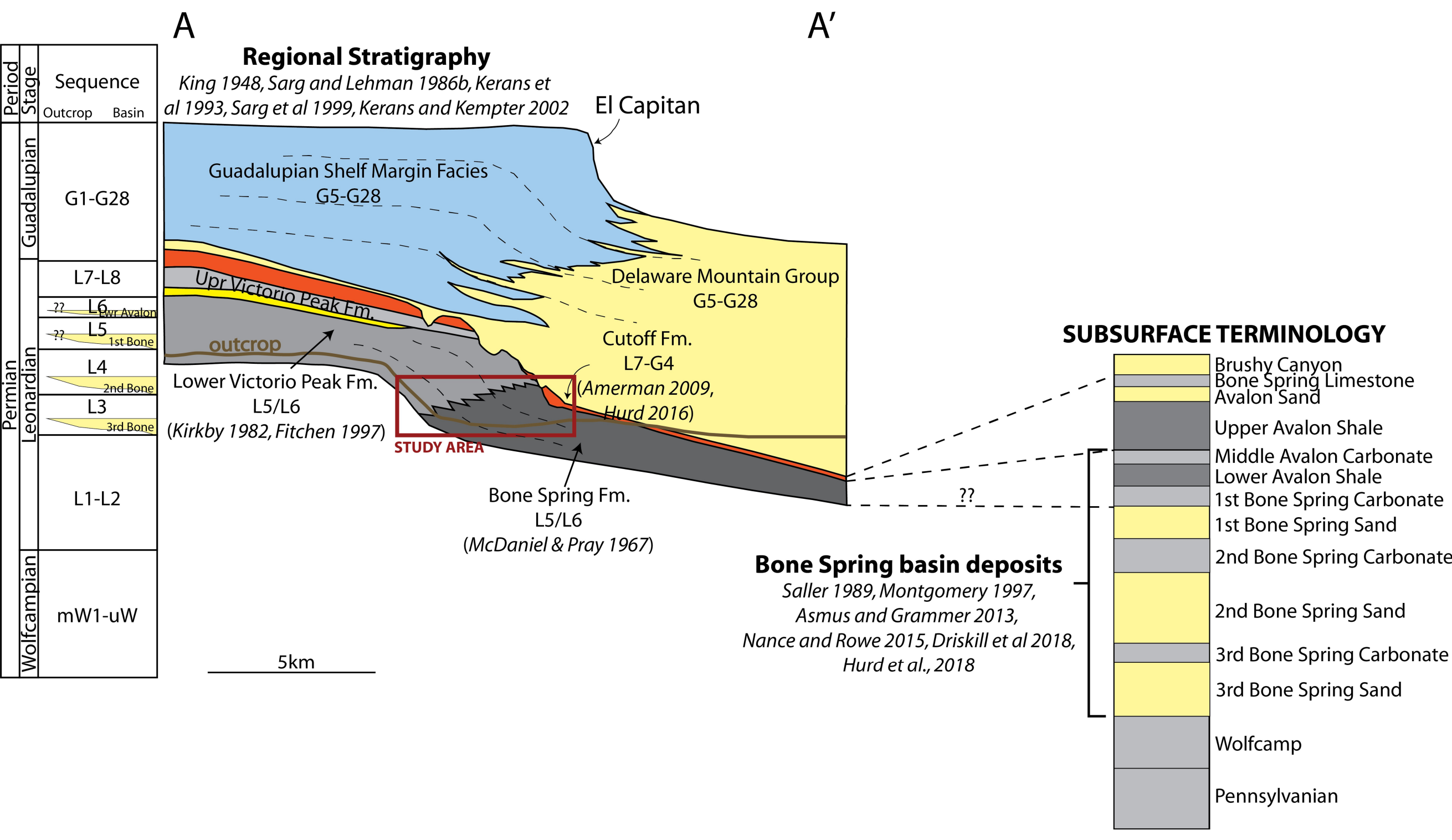


Figure $3 a$

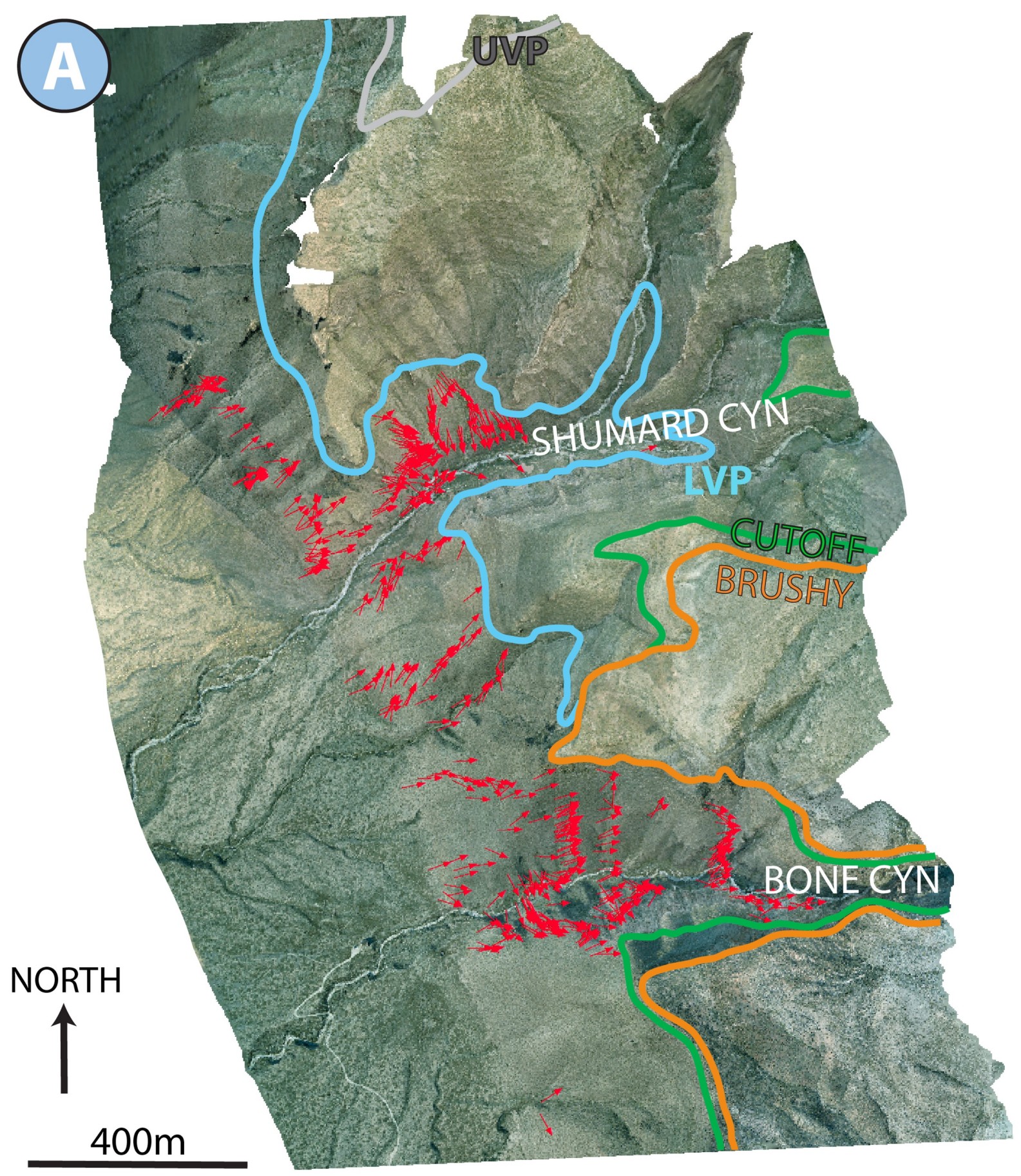




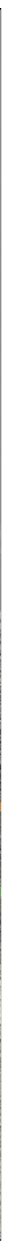


(A) Ca-rich hemipelagic and FACIES 1 thick-beddded bioclastic lime
lime mudstonated
wackestone to packstone lime mudstone $50 \mathrm{~cm}_{-}$
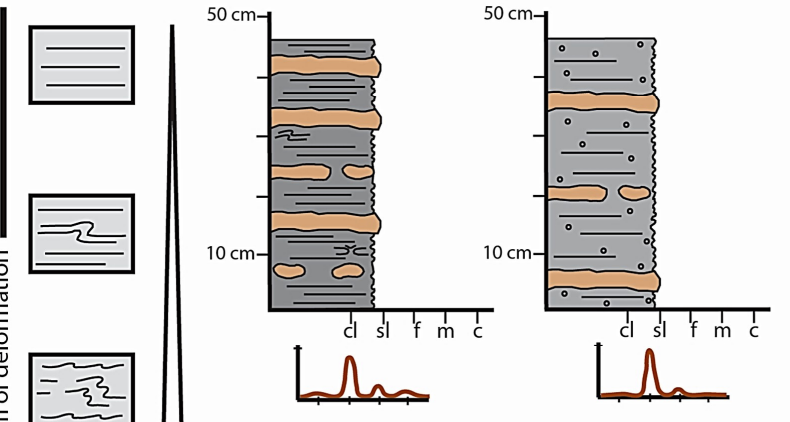
$50 \mathrm{~cm}_{-}$
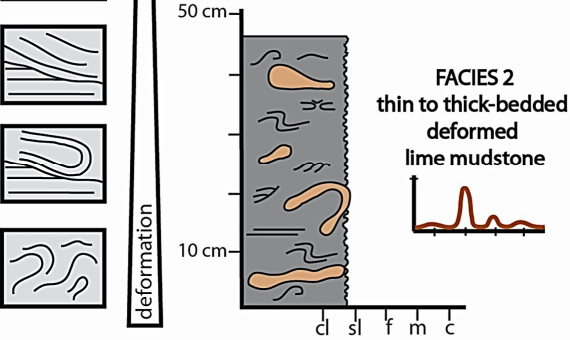

darkness

chert abundance

sed. structures

carbonate mud

(B)

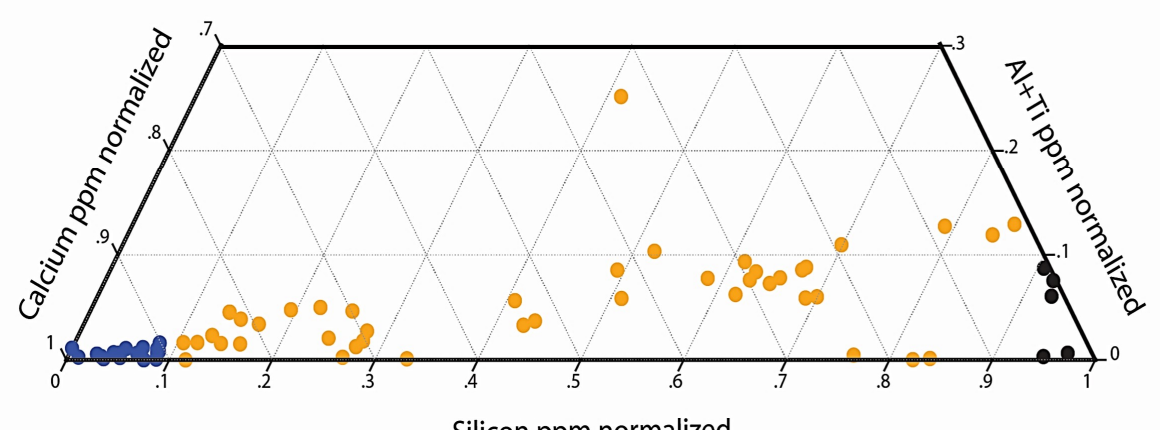

Silicon ppm normalized (c)

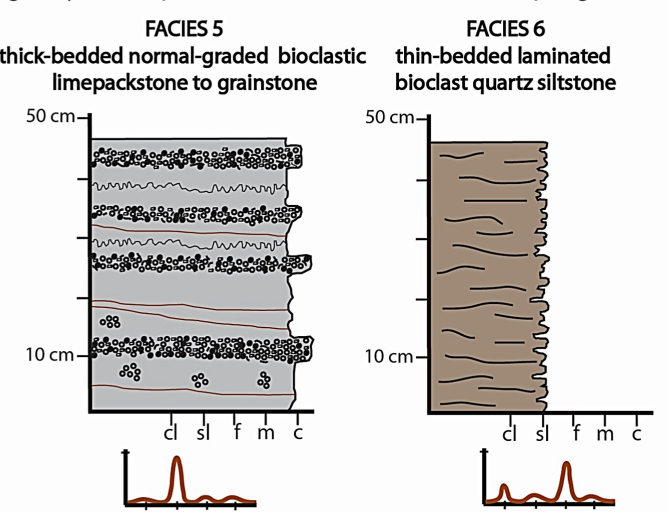

FACIES 7

thin-bedded laminated

quart lime mudstone

and bioclastic packston

$50 \mathrm{~cm}-1$

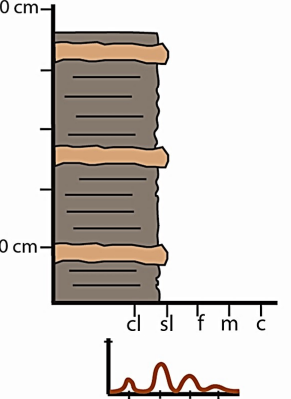

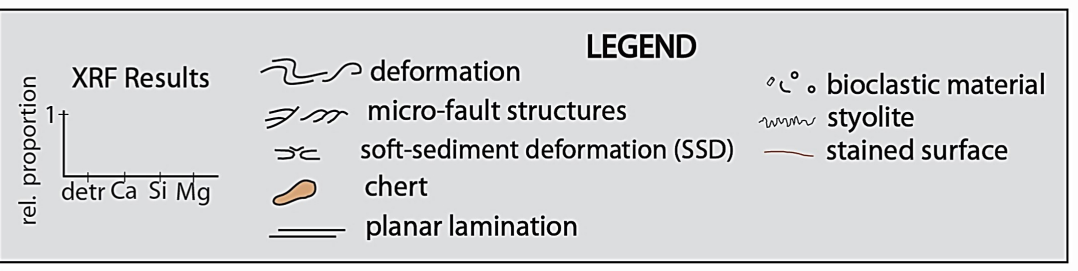

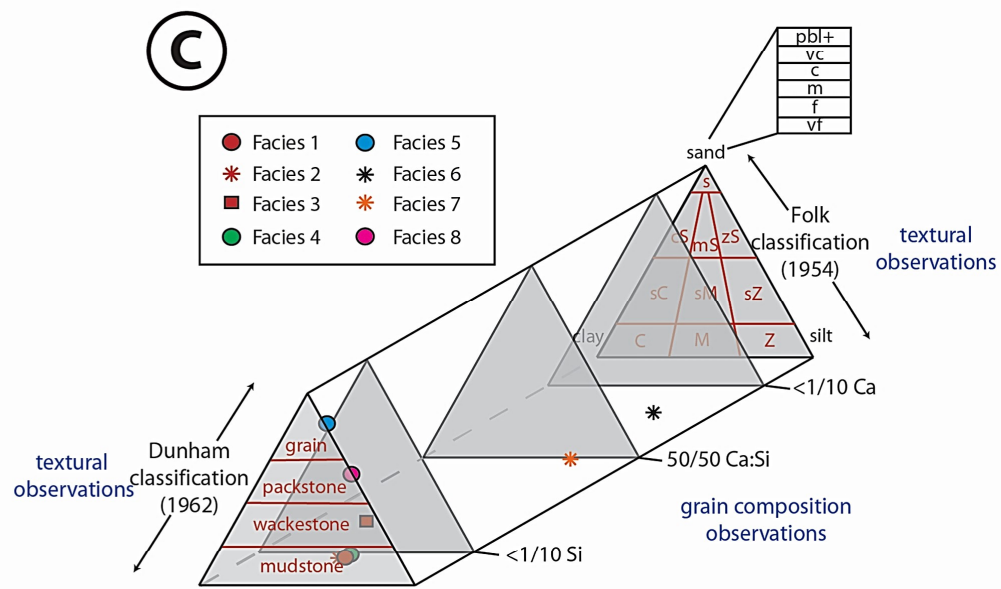




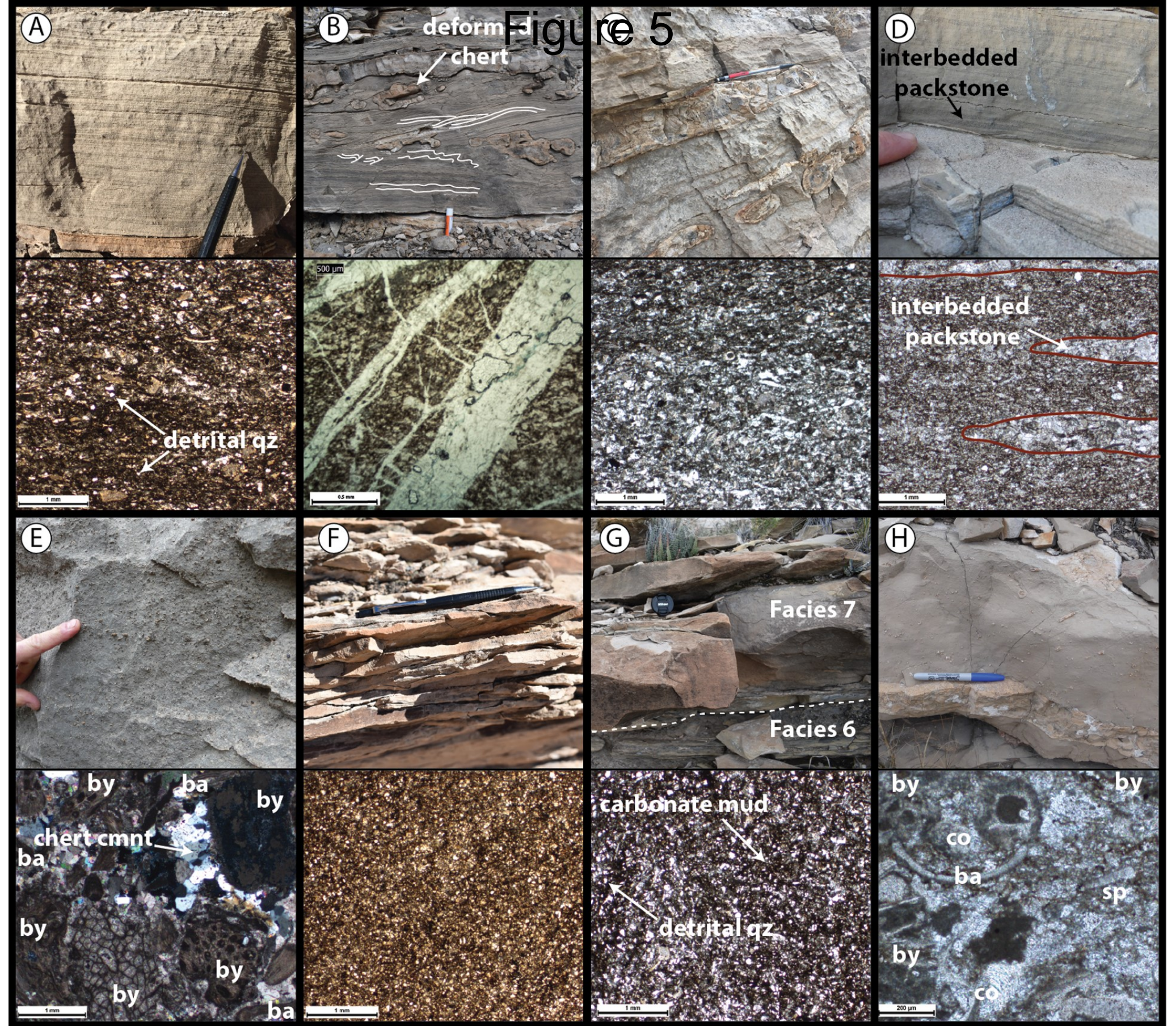


Figure 6

(A)

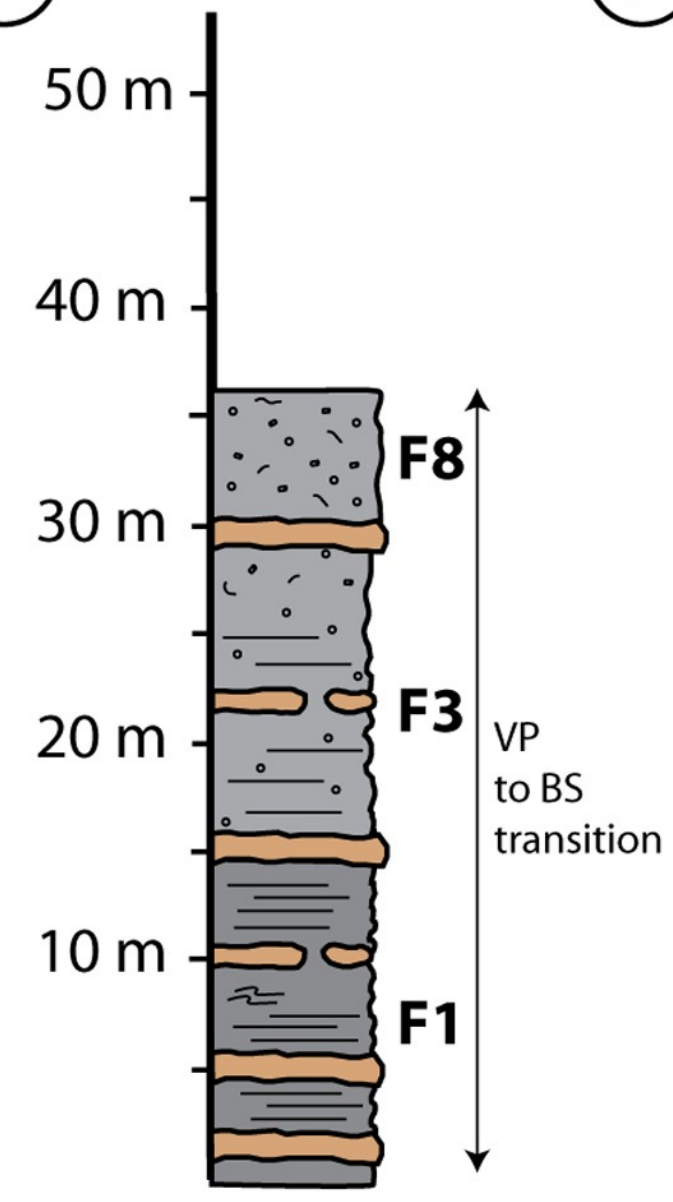

FA1: upwardshoaling carbonate margin
(B) (C)

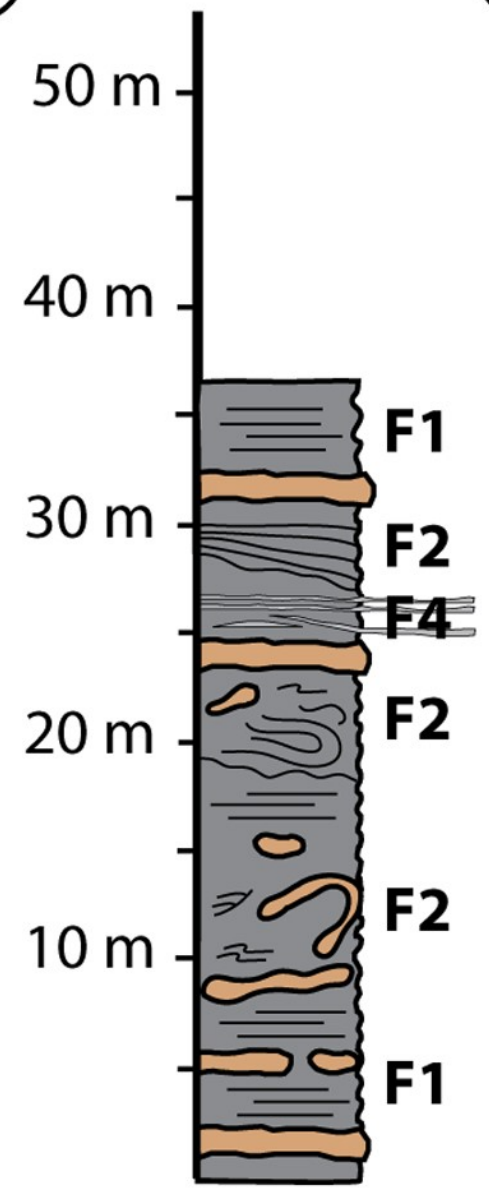

FA2: carbonate slope deposits with mass wasting
(D)

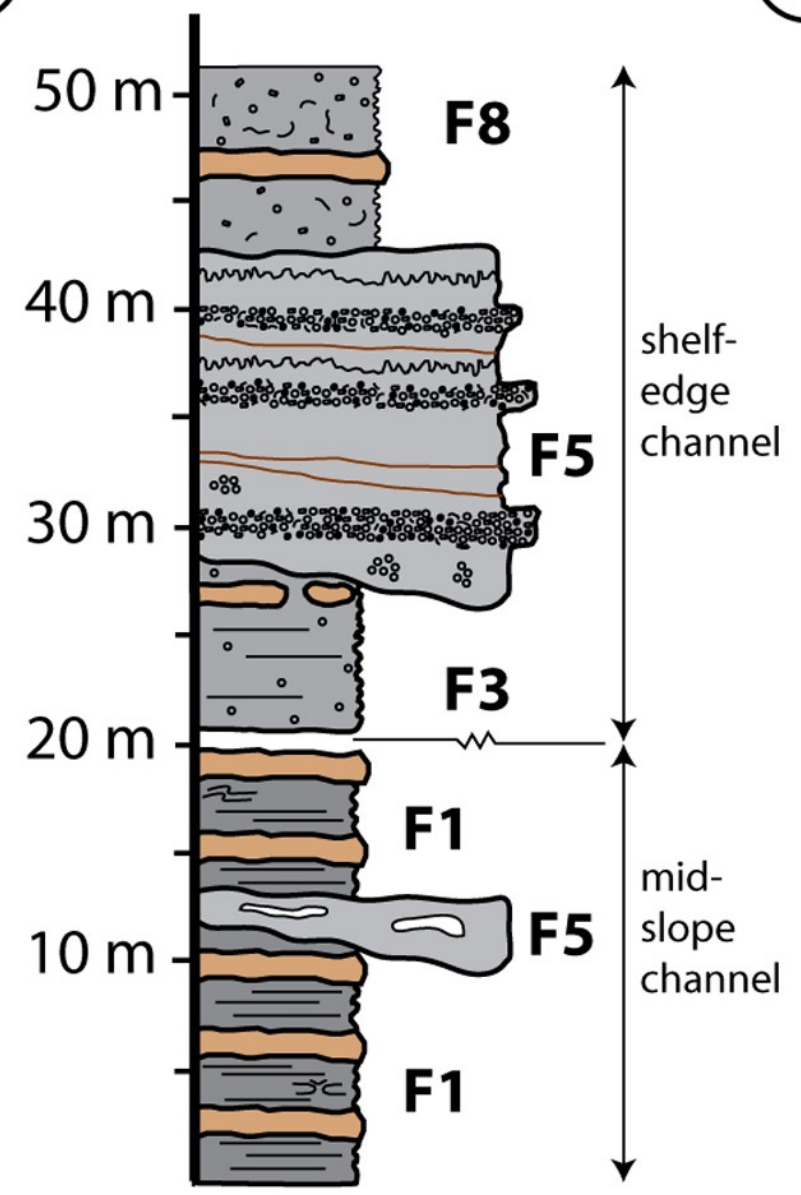

FA3: submarine carbonate channel deposits

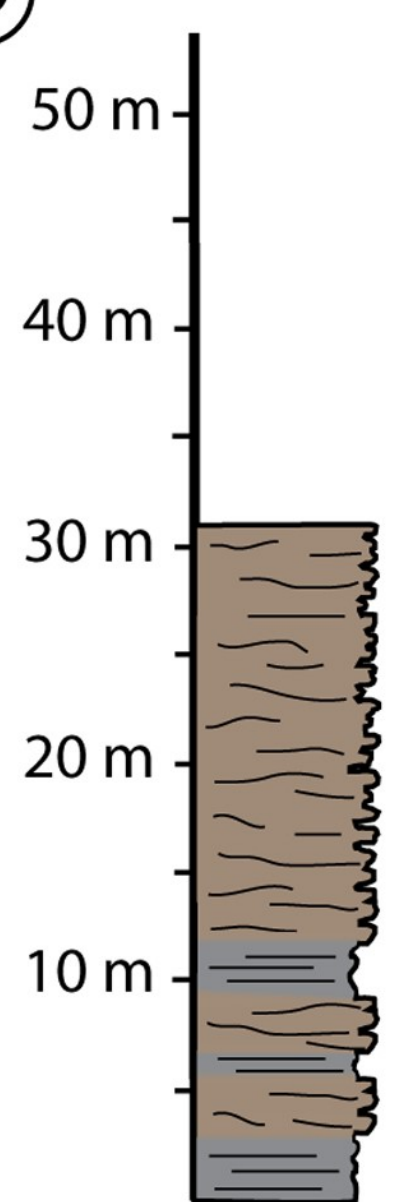

F6

F7
F6
F6
F7

FA4: siliciclastic slope deposits 
Figure 7

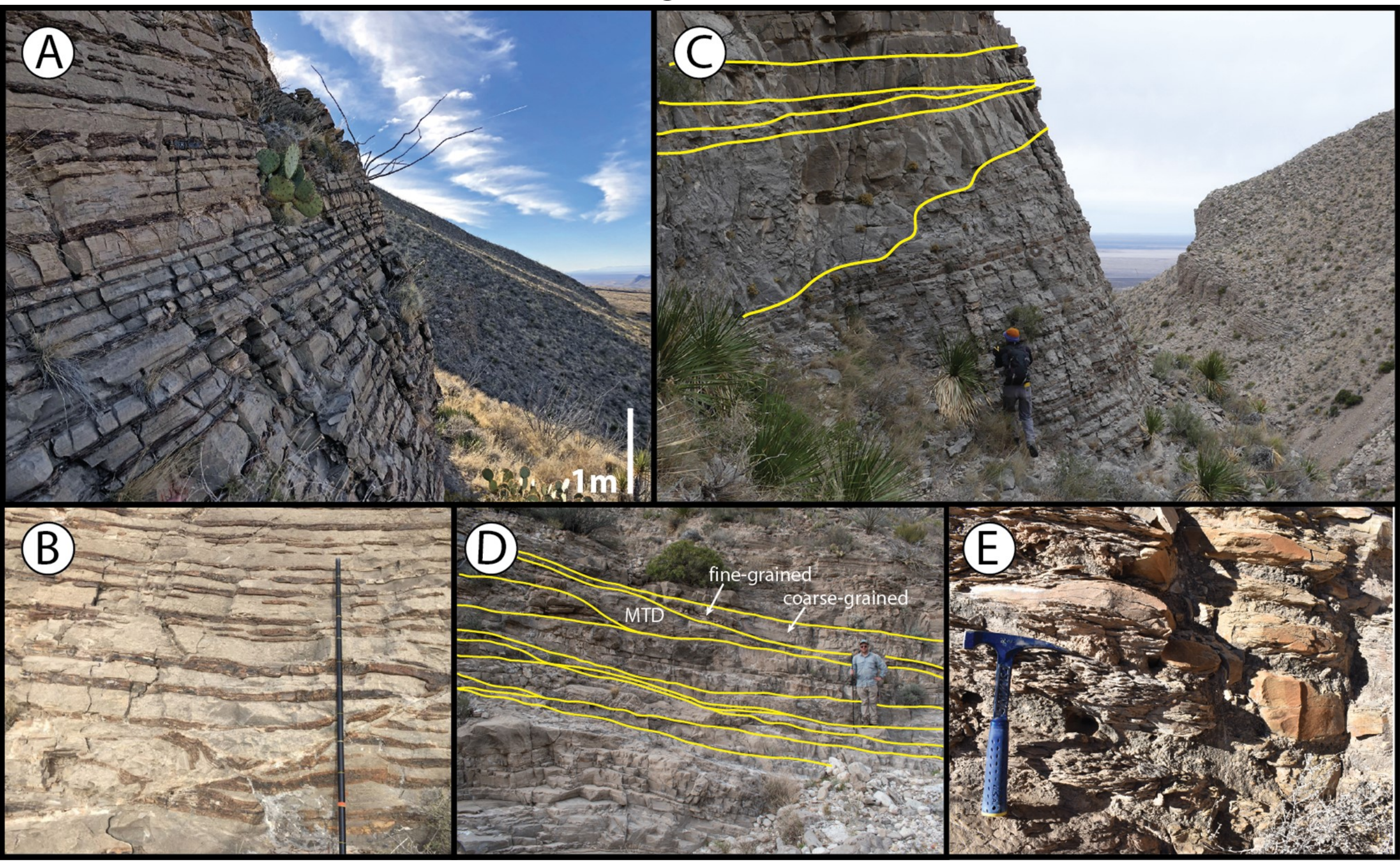




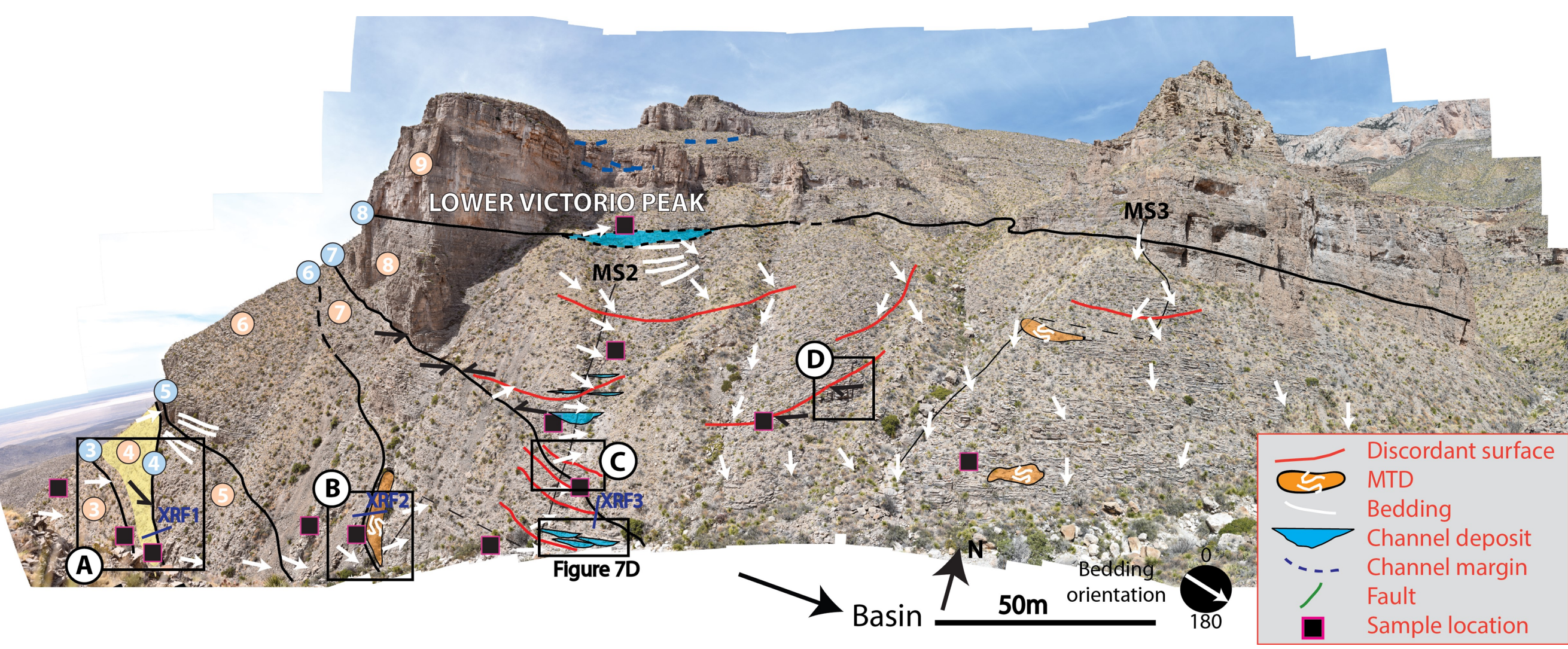




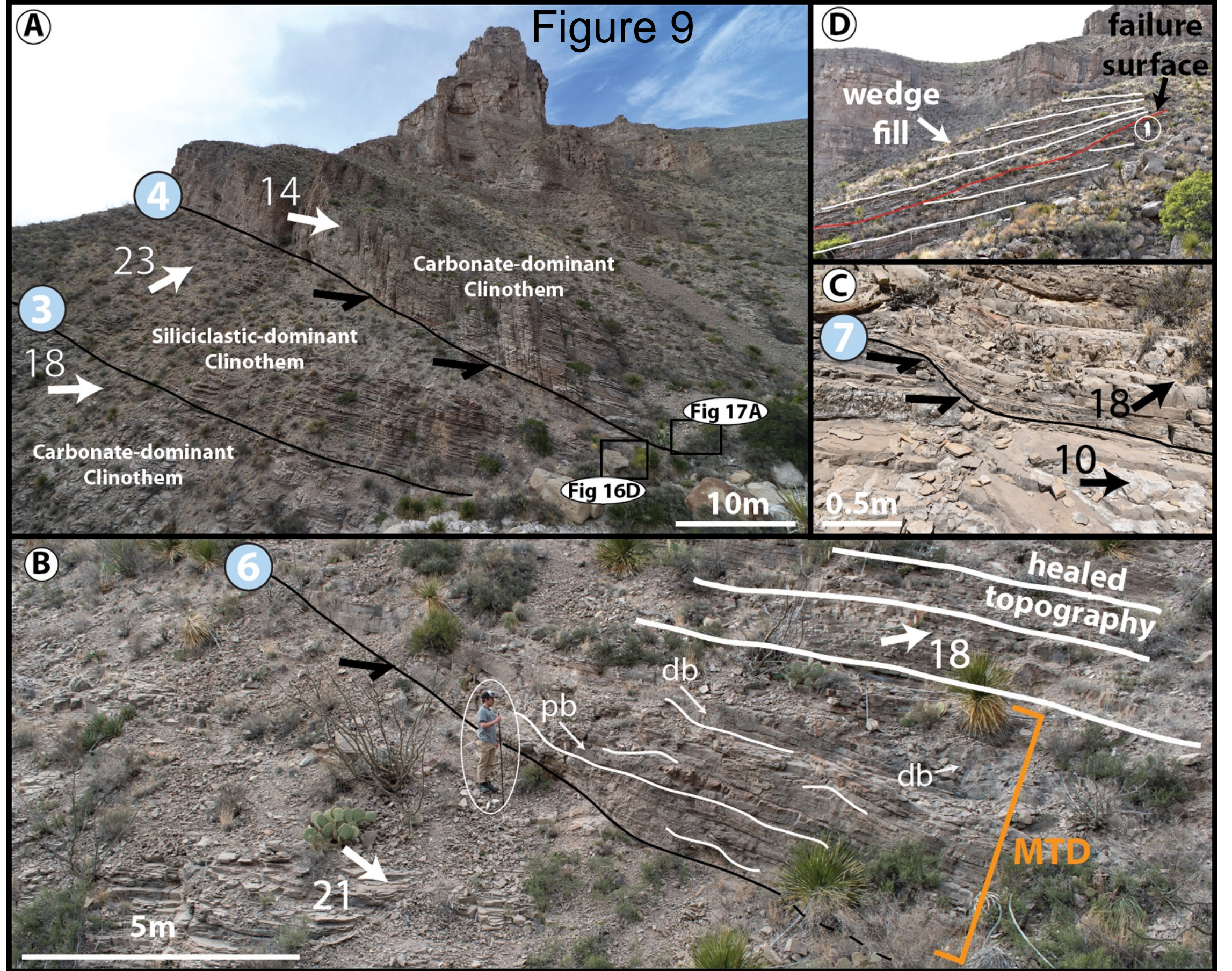




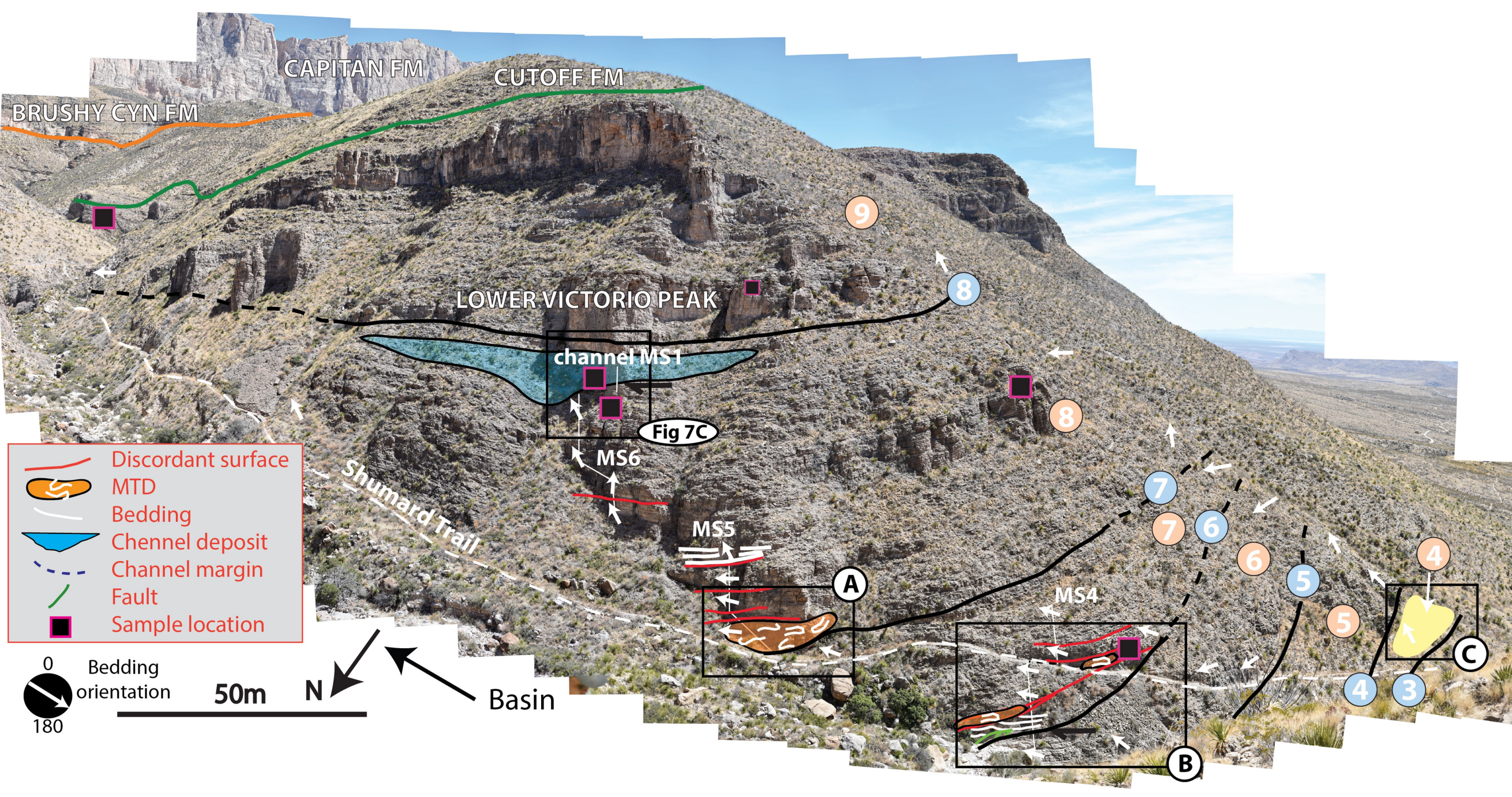




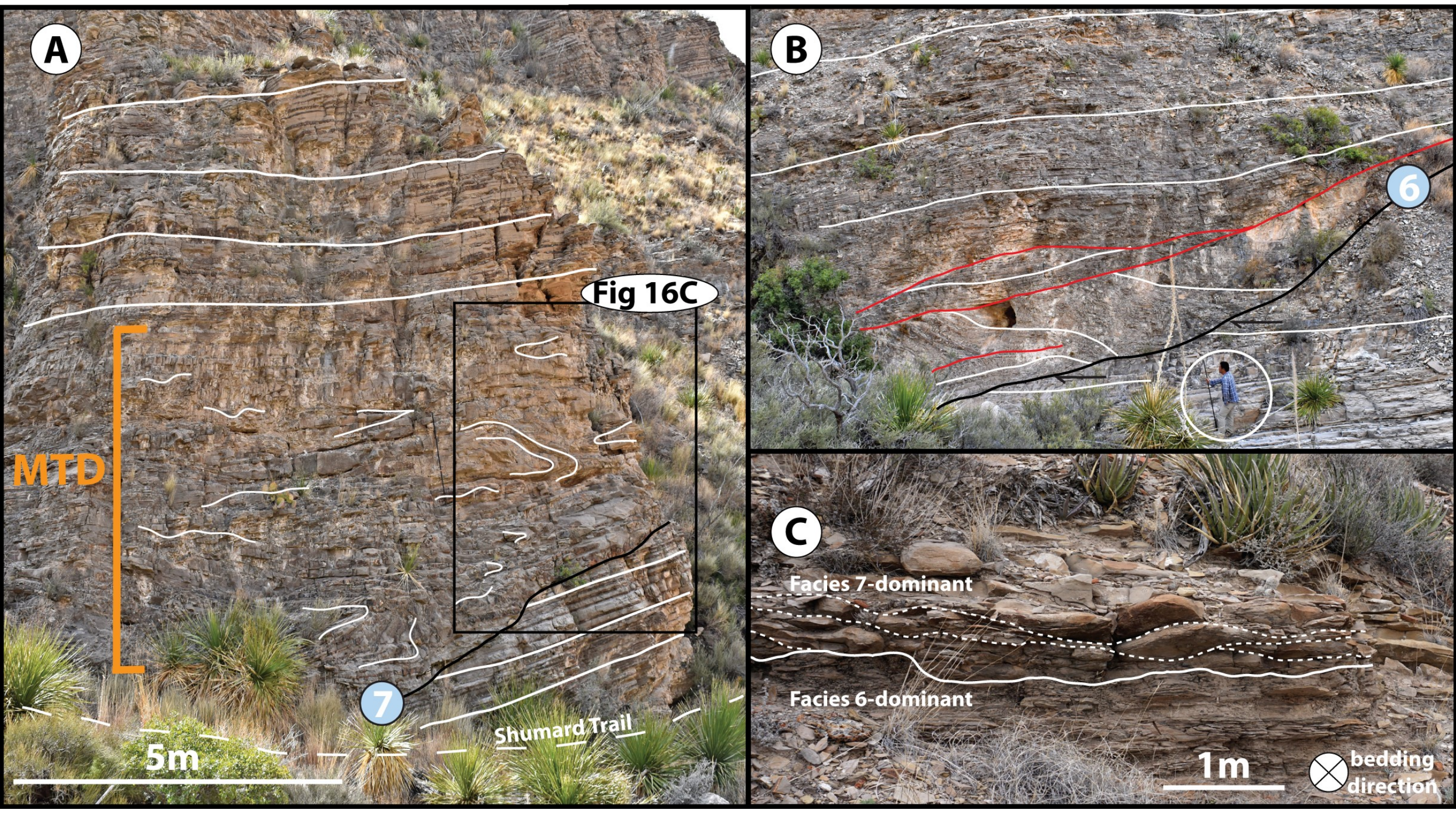


Figure 13

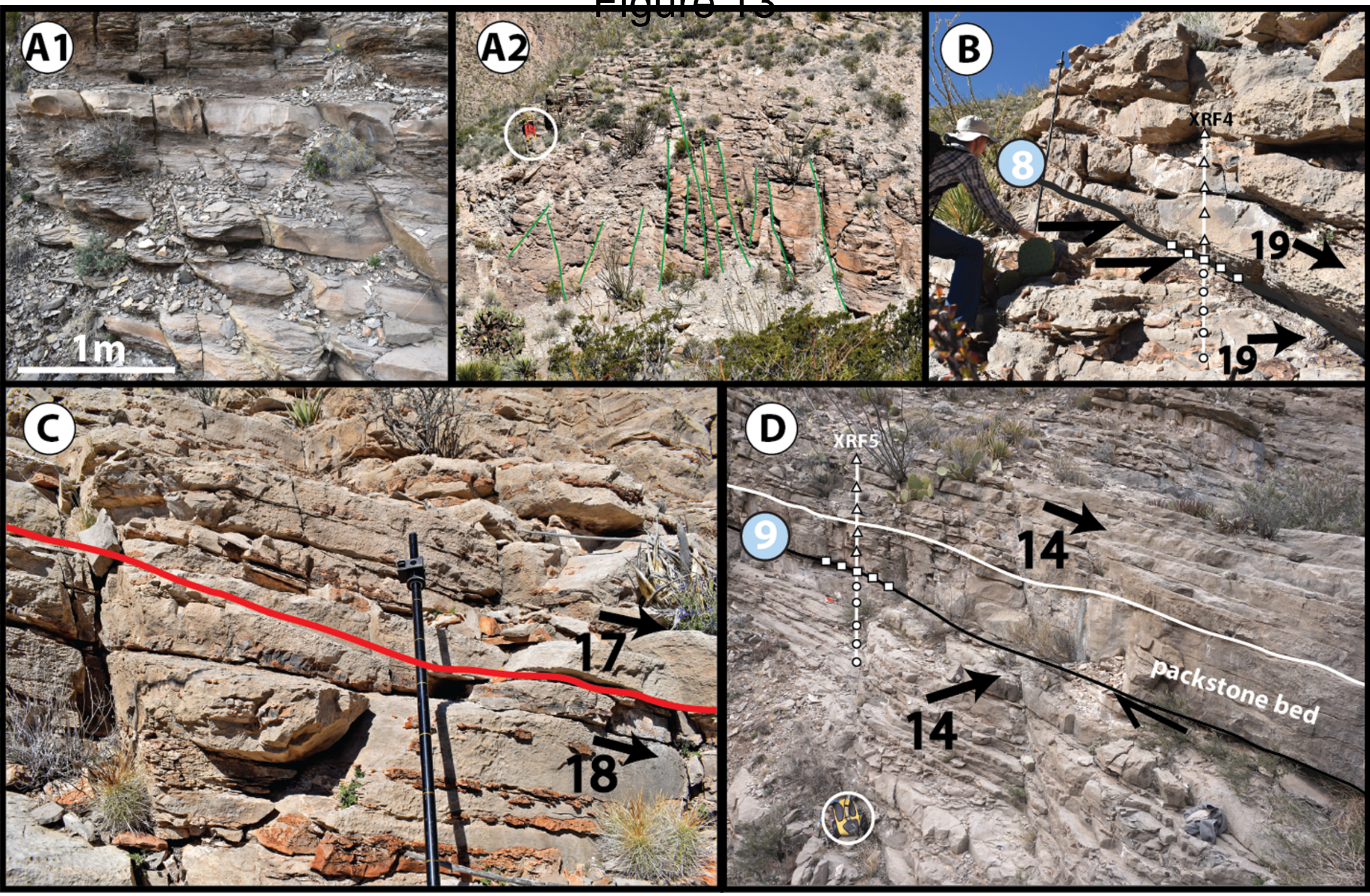


Figure 14

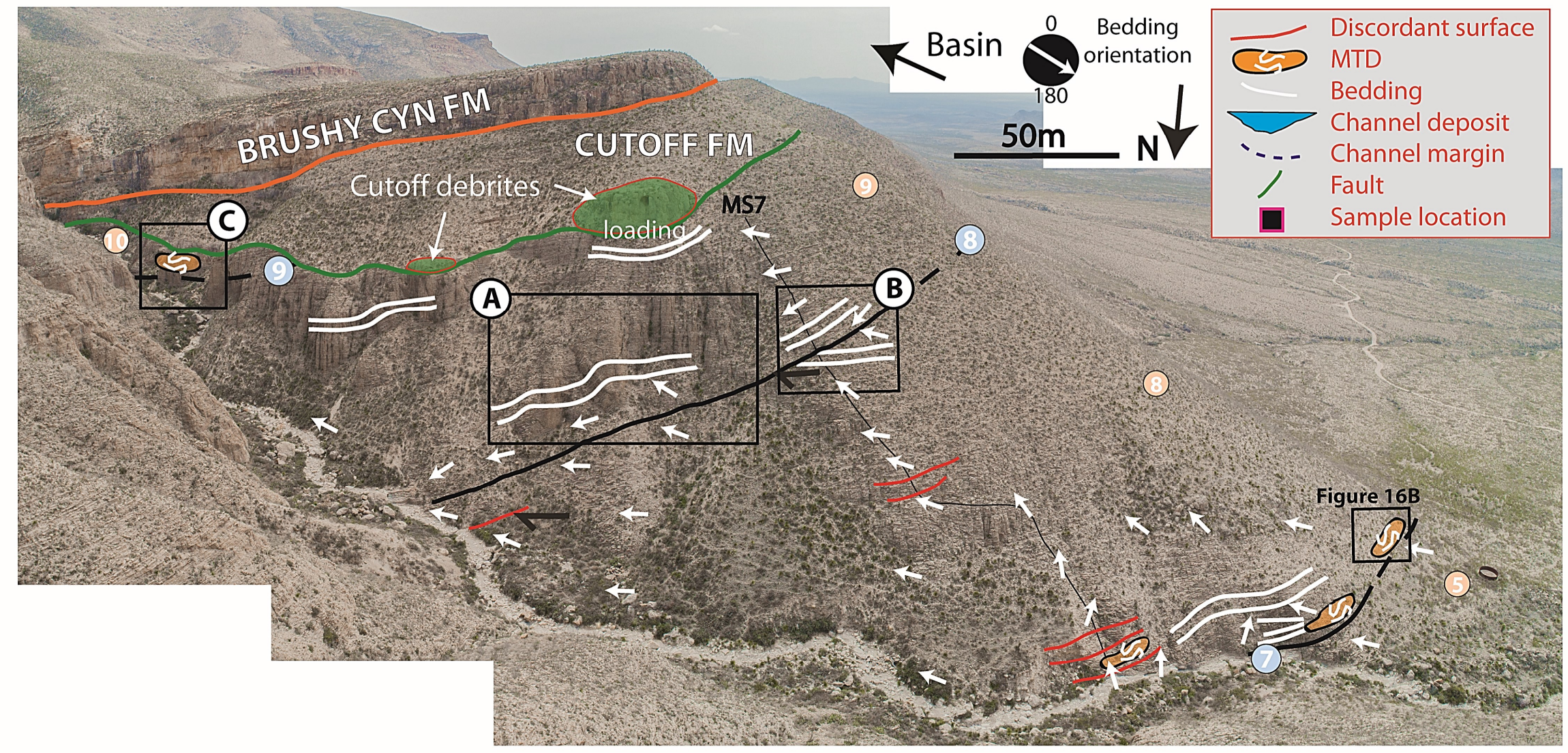




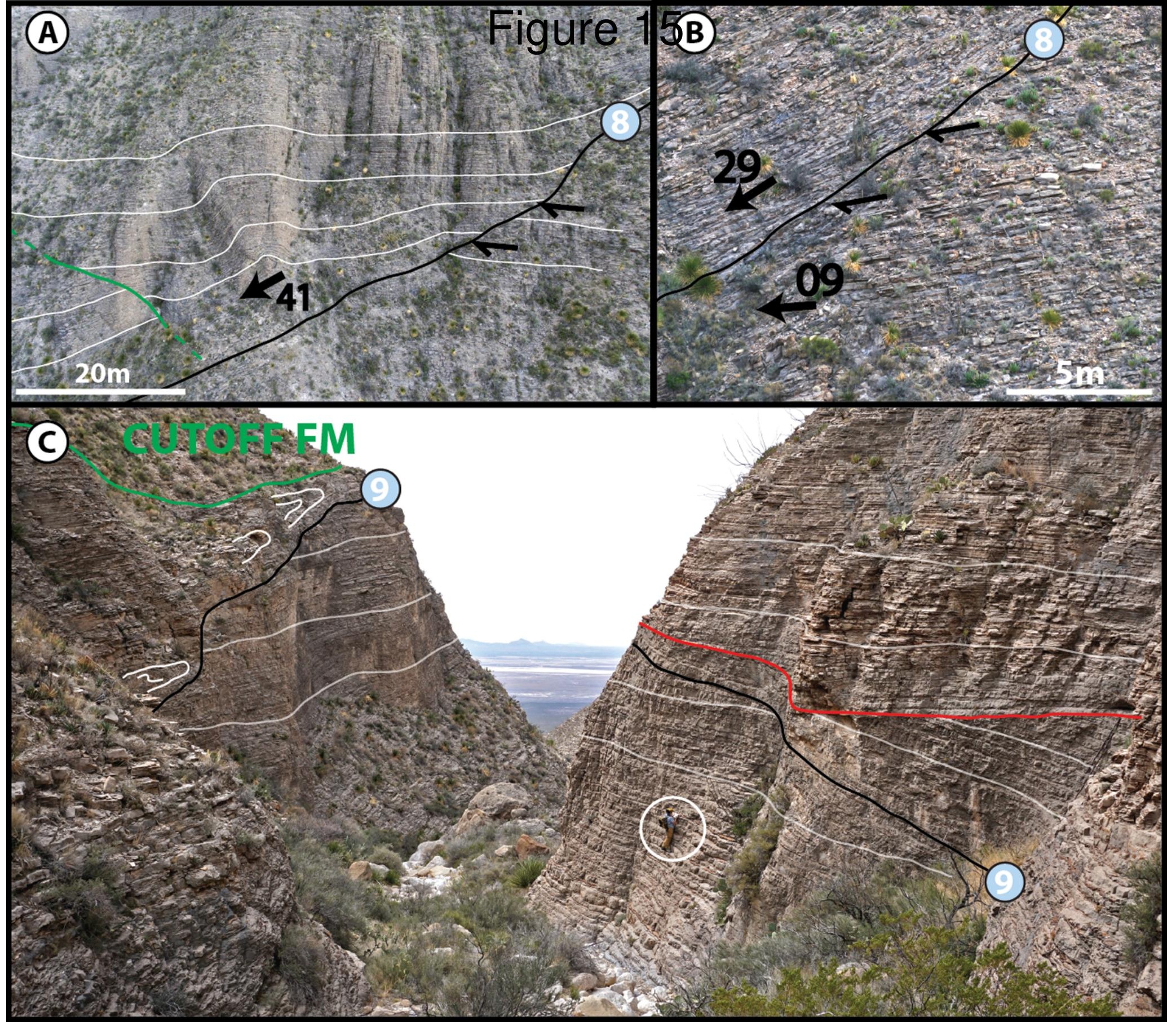




\section{Figure 16}

ㅋ.1

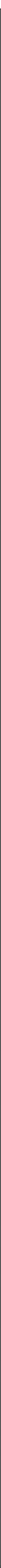




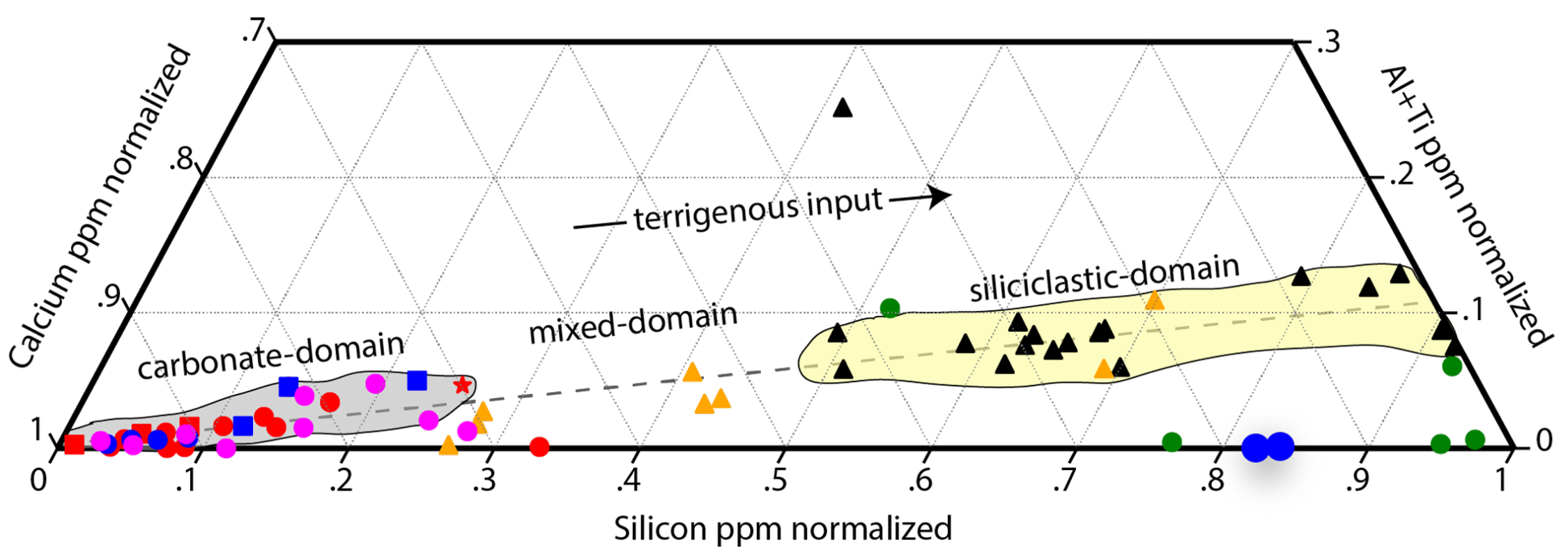

\author{
LEGEND \\ Facies 1 \\ $\downarrow$ Facies 2 \\ Facies 3 \\ Facies 4 \\ Facies 5 \\ $\triangle$ Facies 6 \\ Facies 7 \\ Facies 8 \\ chert
}

Silicon ppm normalized 


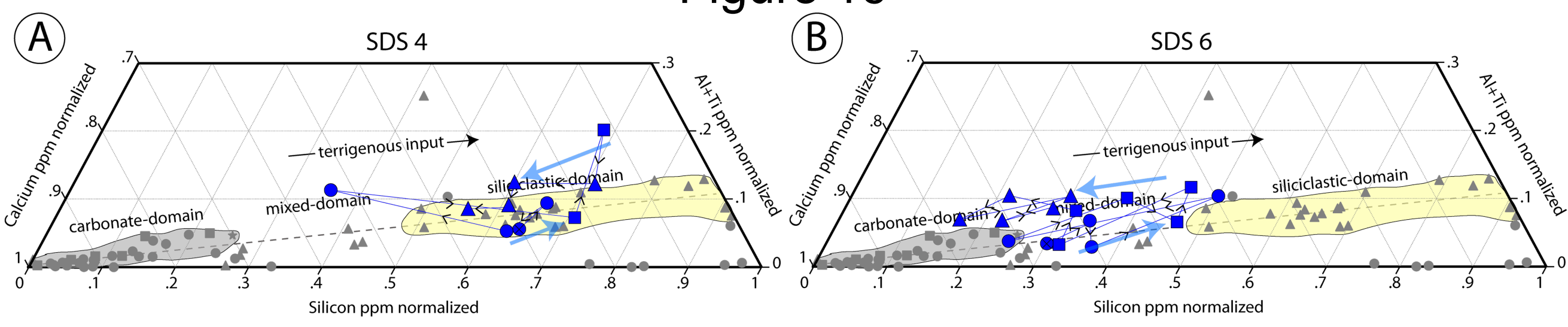

(C)

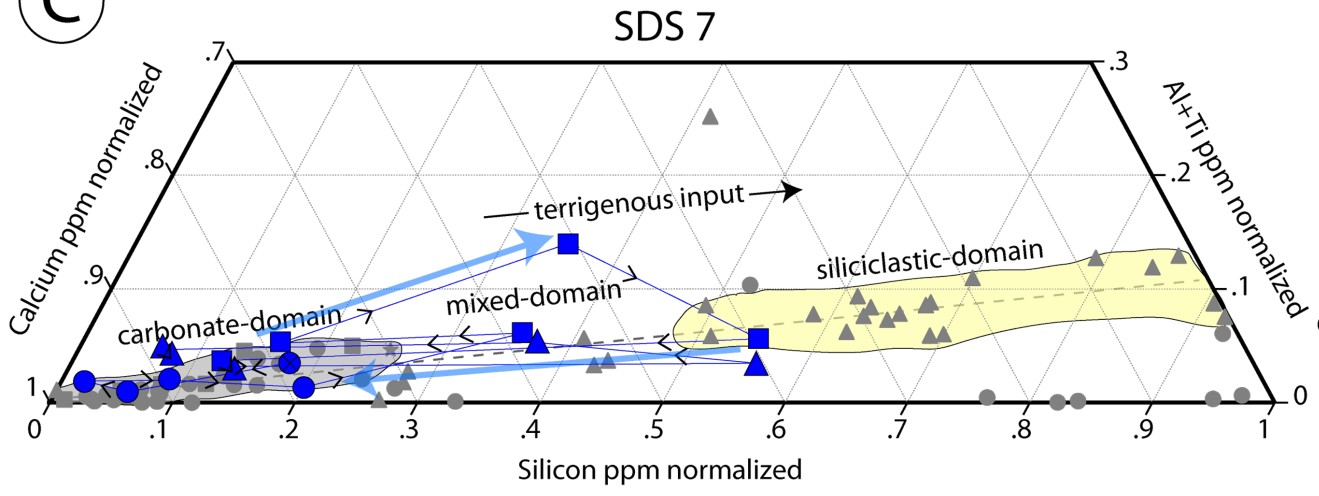

\section{SDS 7}

E

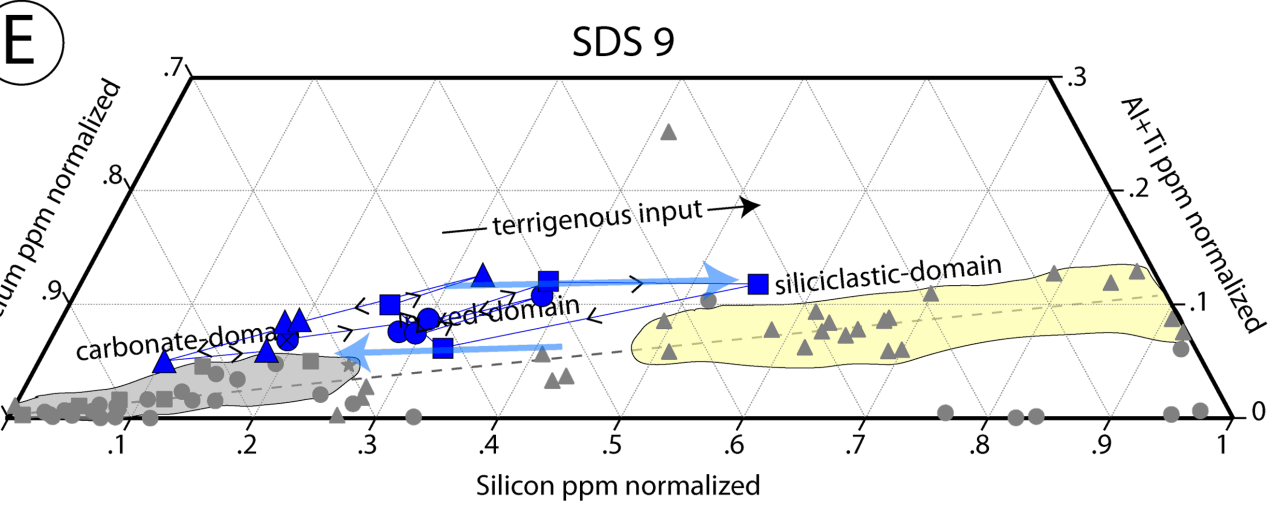

(D)

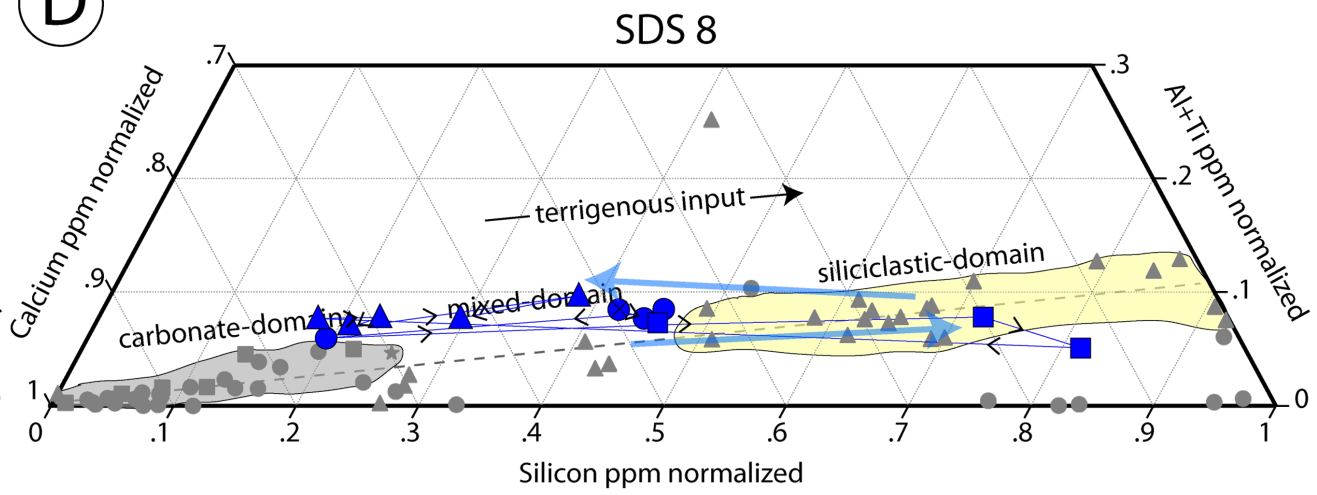




\section{Figure 20}
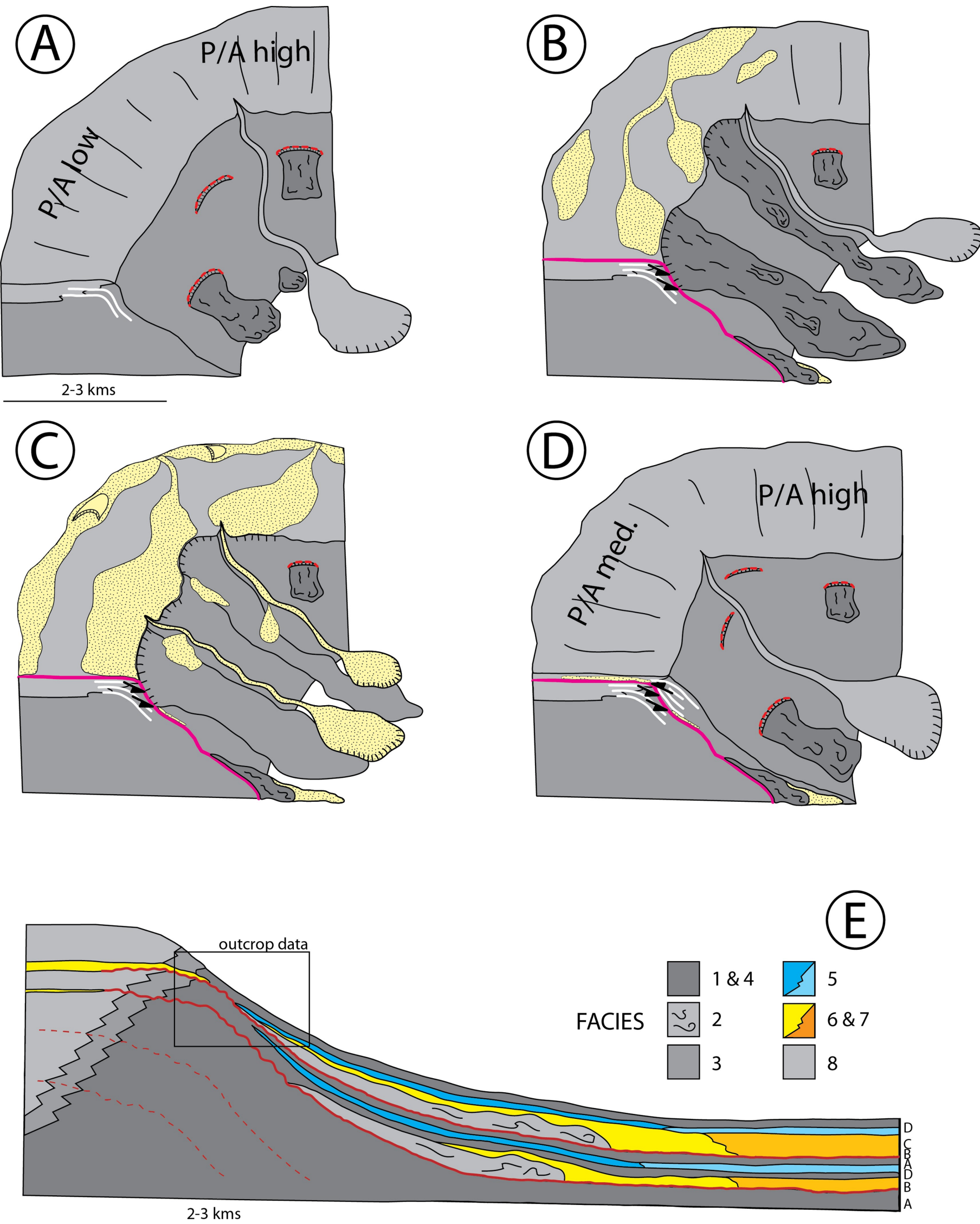


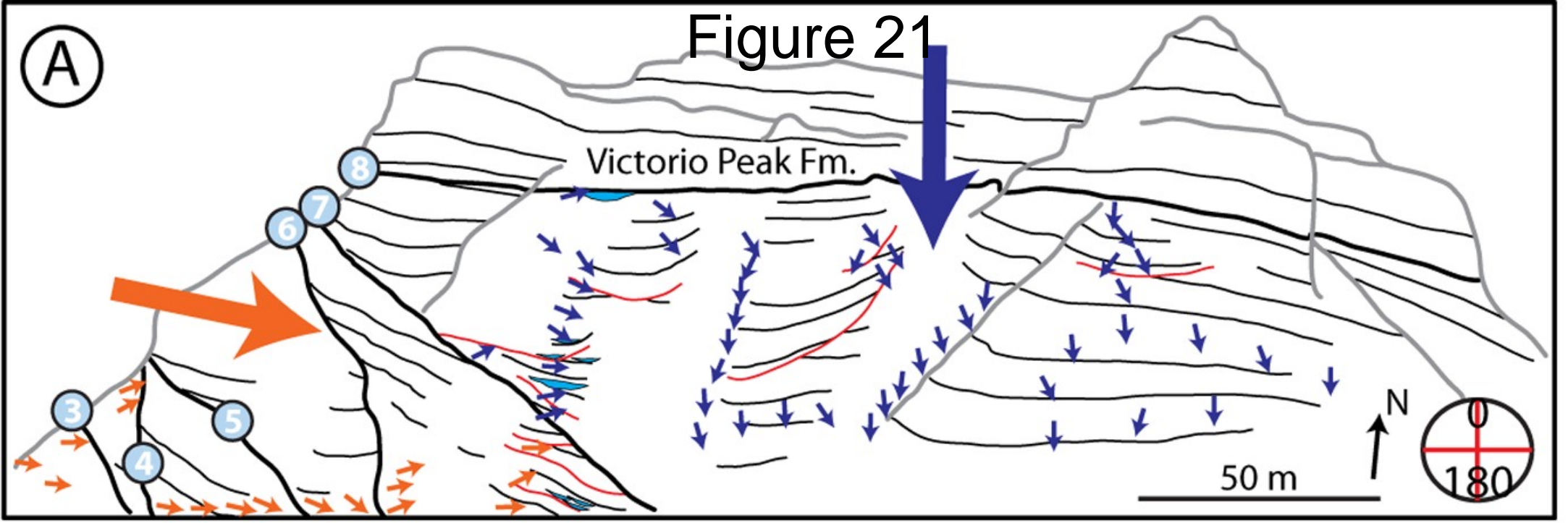

(B)

(C) inflection point
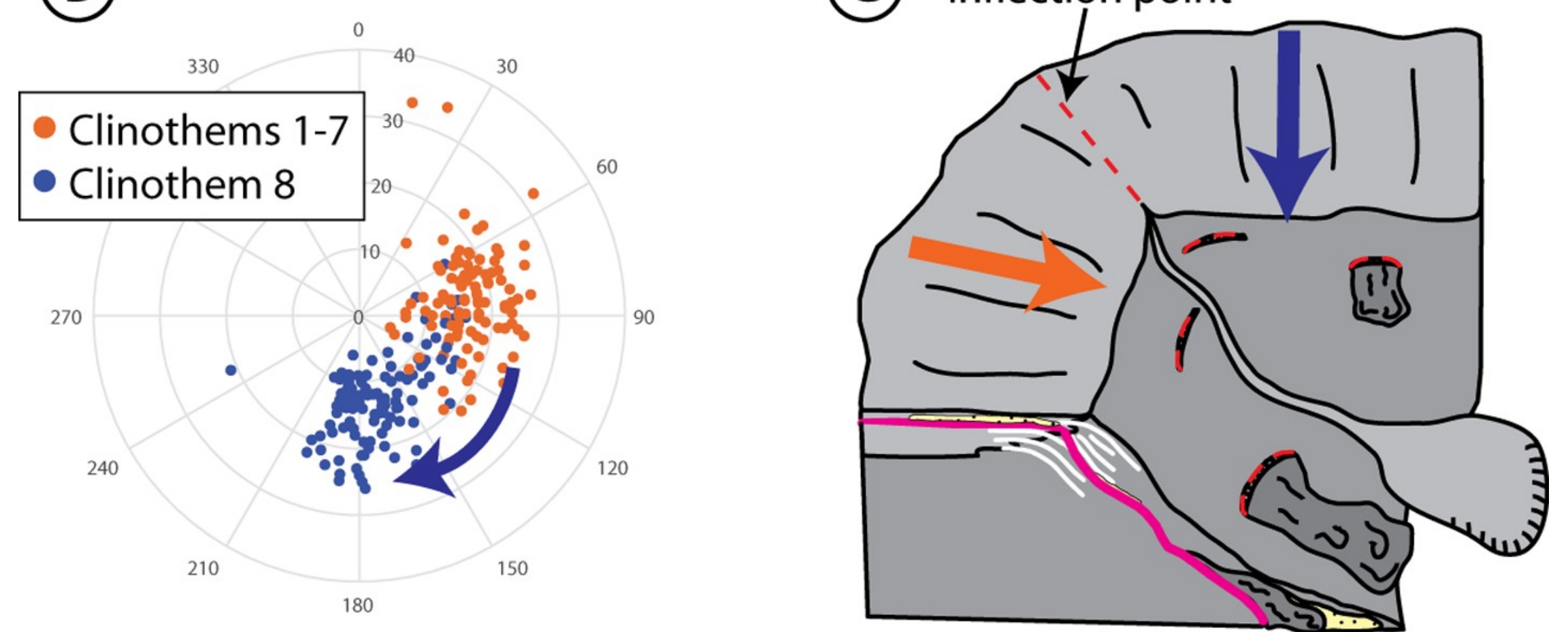
Figure 22

(A)

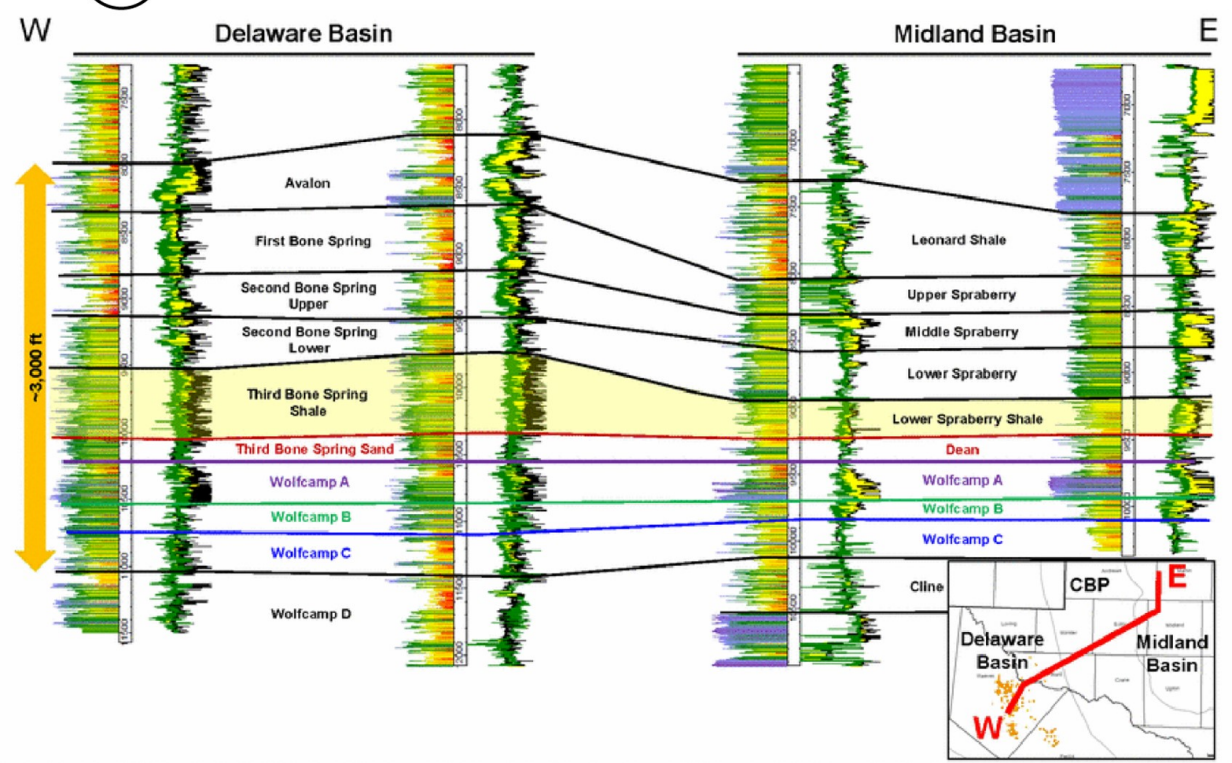

(B)

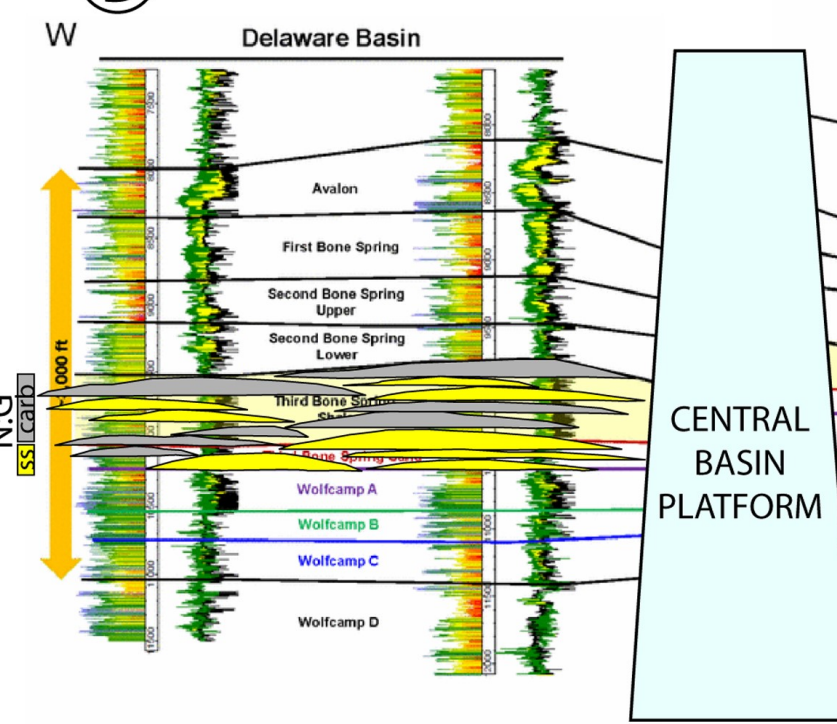

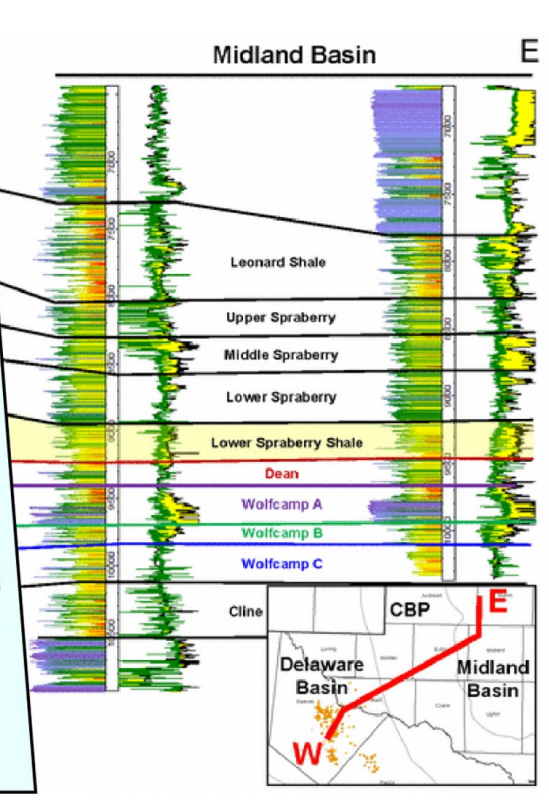




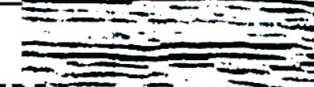

$N W=1 \mathrm{~km}$

(C)

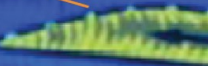

Capitan Fm Brushy Cyn Em

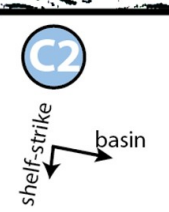

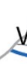

Victorio Peak F Victorio Peak Fm
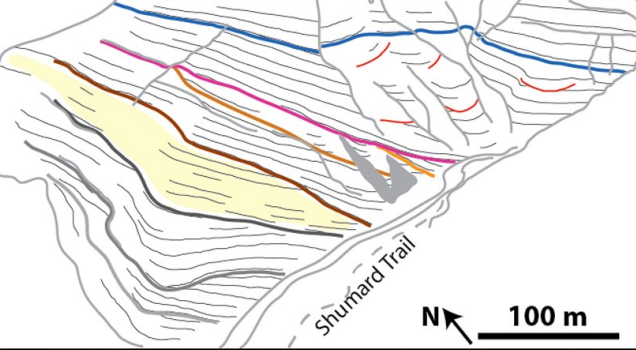

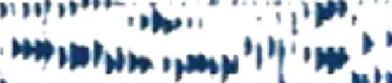
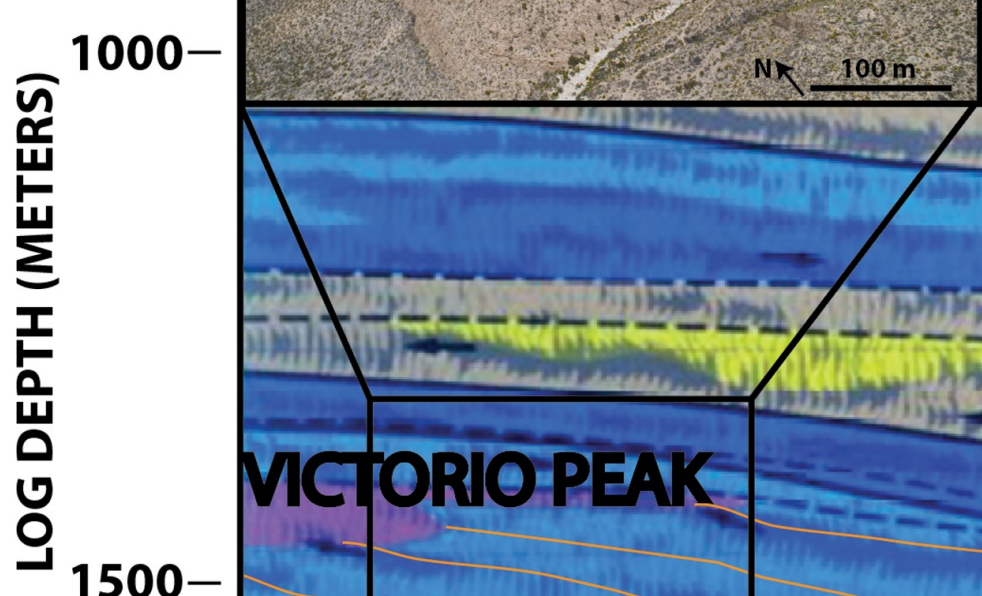

thensming

in

inth

\section{BONESPRING CARBONATE}

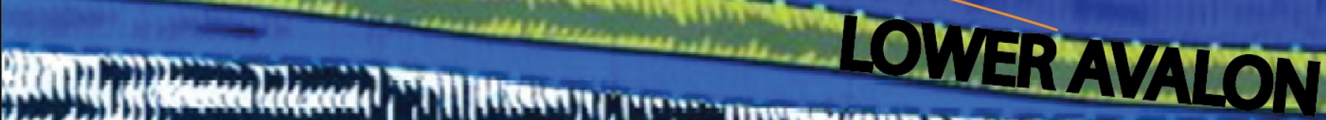


Figure A.1

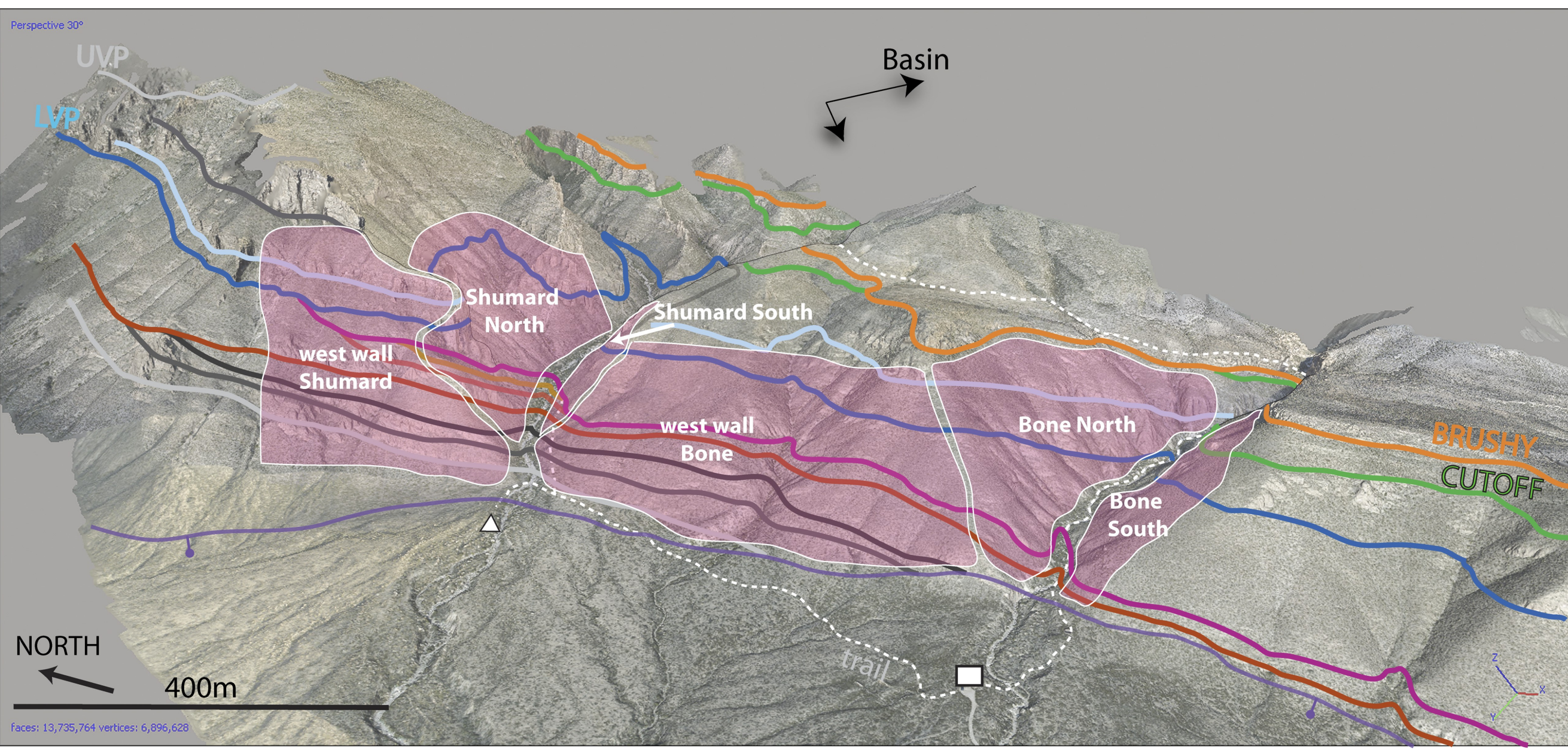


Figure A.2

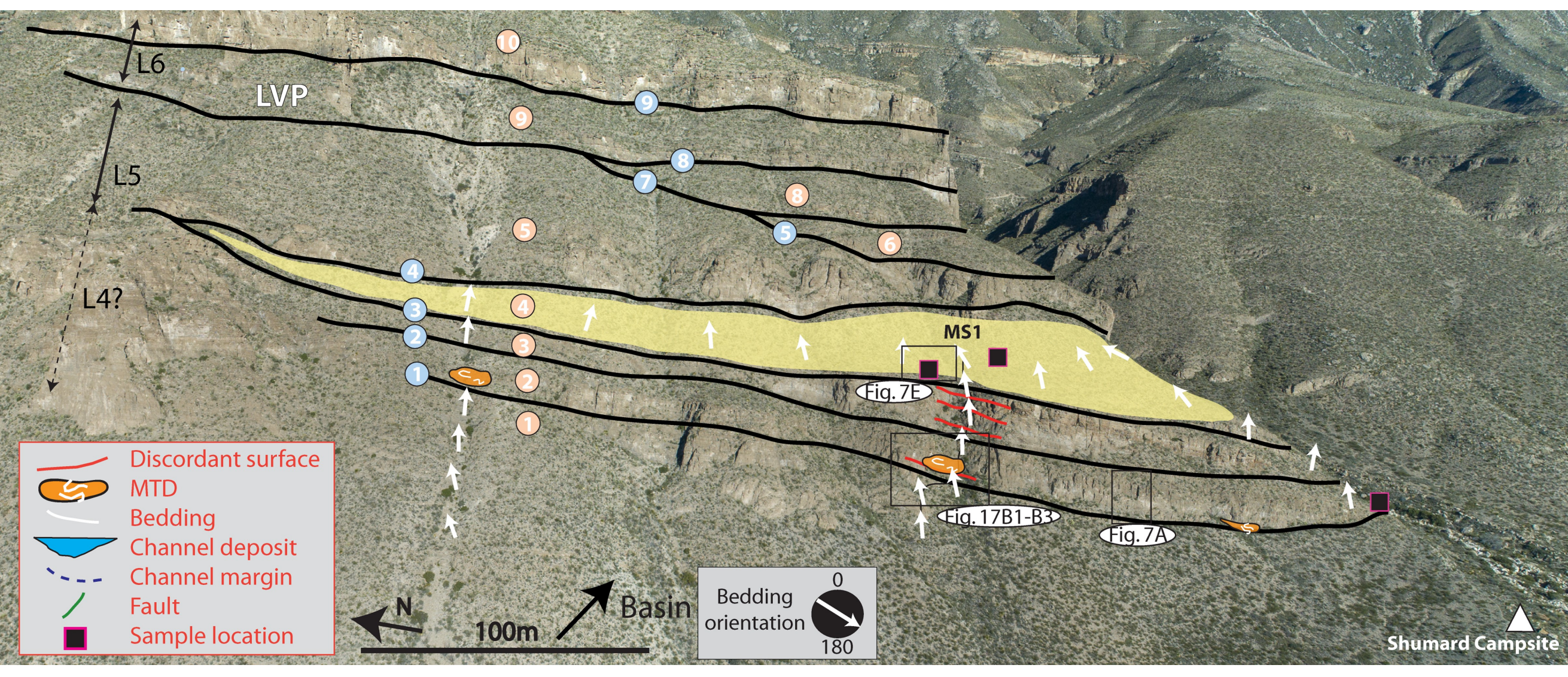


Figure A.3

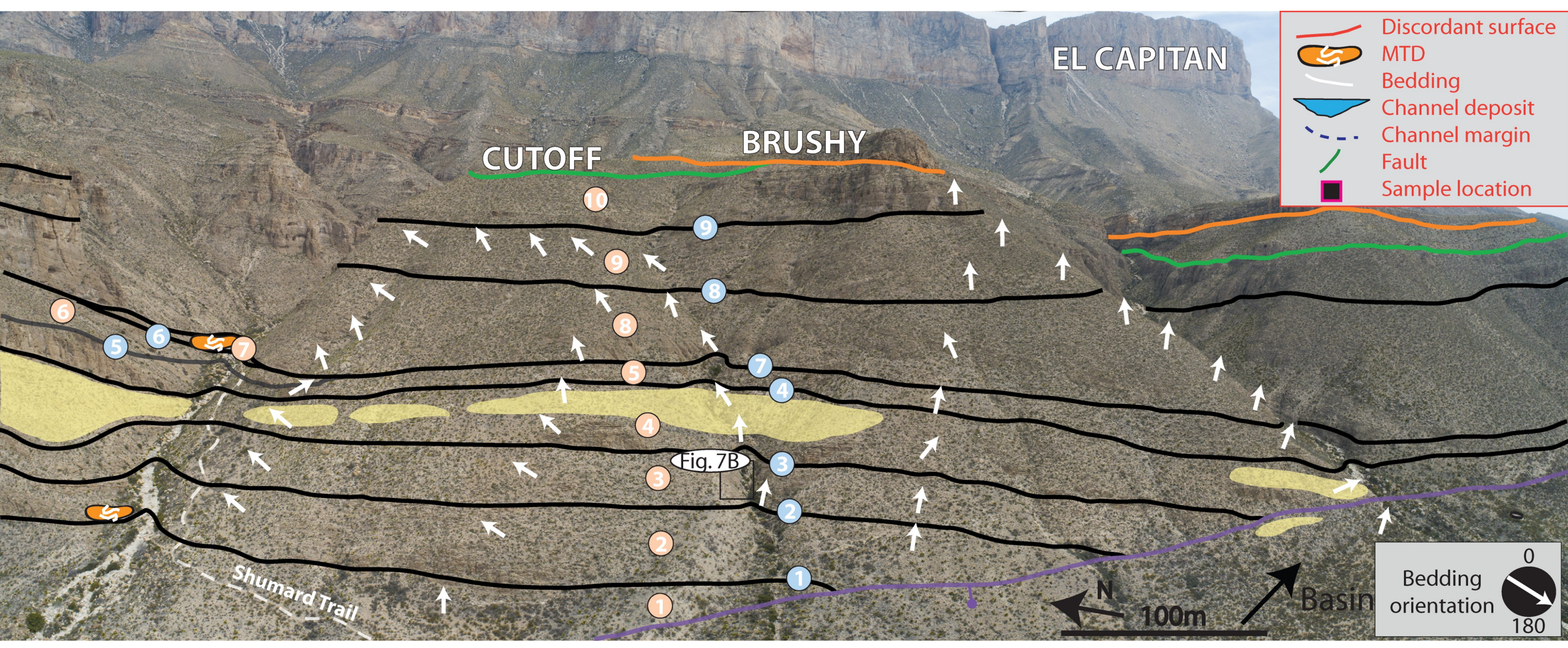

